\title{
Site C0017
}

\author{
Expedition 331 Scientists $^{2}$
}

\section{Chapter contents}

Background and objectives. ......... 1

Operations................... 1

Lithostratigraphy.............. 2

Biostratigraphy ...............4

Petrology.................4

Geochemistry ................ 5

Microbiology ...............6

Physical properties . . . . . . . . . . . 8

References.................. 10

Figures.................. 12

Tables....................... 39

\section{Background and objectives}

Integrated Ocean Drilling Program (IODP) Site C0017 is located $1.6 \mathrm{~km}$ east of the hydrothermal vent sites in the central valley of Iheya North Knoll (see Fig. F3 in Expedition 331 Scientists, 2011a). Based on the multichannel seismic (MCS) survey (see Figs. F5 and F6 in Expedition 331 Scientists, 2011a), the uppermost 100 meters below seafloor (mbsf) probably consists of hemipelagic sediment. At $\sim 100 \mathrm{mbsf}$, a strong seismic reflection is continuous from the hydrothermal vent sites at Site C0016 eastward through Sites C0013 and C0014. This reflection represents a potential interface between hemipelagic sediments and pyroclastic flow deposits. Below this reflection the subseafloor structure becomes obscure. Potential volcanic basement, however, may be identifiable at $\sim 450 \mathrm{mbsf}$ at Site C0017.

Heat flow measured in the sediments near Site C0017 is quite low (see Fig. F2 in Expedition 331 Scientists, 2011c). The surficial thermal gradient is one order of magnitude lower than the average thermal gradient of the nonhydrothermal, trough-filling sediments in the middle Okinawa Trough. This low heat flow anomaly strongly suggests that Site C0017 is located within a largescale local recharge zone. Heat flow data also indicate that there are areas with relatively high thermal gradients several hundreds of meters from Site C0017, suggesting that the local recharge/discharge boundary of the Iheya North hydrothermal system may be quite narrow in the east-west direction in the vicinity of Site C0017.

The scientific objectives for Site C0017 are to understand the potential discharge and recharge dynamics around the central valley of Iheya North Knoll and to clarify the interaction between subseafloor physical-chemical variations and microbial community structures and functions.

\section{Operations Arrival at Site $\mathrm{C} 0017$}

The D/V Chikyu moved to Site C0017 and began coring on the night between 26 and 27 September 2010 (Fig. F1; Table T1). The plan was to core as deep as possible in the $2-3$ days available. 


\section{Hole C0017A}

After tagging the seafloor on 27 September 2010 at $1154.5 \mathrm{~m}$ drilling depth below seafloor (DSF), Hole C0017A was spudded with the hydraulic piston coring system (HPCS), retrieving mudline and penetrating to $8.8 \mathrm{mbsf}$. The bit pulled out of hole on core retrieval, ending Hole C0017A.

\section{Hole C0017B}

Hole C0017B was washed and drilled down to the penetration depth of Core 331-C0017A-1H on 27 September 2010 and then shot with the HPCS just 1 $\mathrm{m}$ south of Hole C0017A. Penetration and recovery were a perfect $9.5 \mathrm{~m}$, but again the bit pulled out when we retrieved the core, ending Hole C0017B.

\section{Hole C0017C}

On 27 September 2010, the Chikyu offset $\sim 8 \mathrm{~m}$ northeast to begin drilling deeper. Core 331C0017C-1H was shot with the HPCS after washing and drilling down to the penetration depth of Core 331-C0017B-1H. Core 331-C0017C-2H was shot with the HPCS, penetrated fully, and recovered $8.5 \mathrm{~m}$ of sediment with a little overpull at the end. To avoid getting stuck in the formation, we switched to the extended shoe coring system (ESCS) for Core 331C0017C-3X. However, upon retrieval of the core barrel we found the shoe and core catcher sub were missing and decided to abandon the hole. An HPCS inner barrel was run through the drill string after pulling out, to ascertain that nothing was left inside the pipe.

\section{Hole C0017D}

Hole C0017D was spudded on 27 September 2010, 5 $\mathrm{m}$ northeast of Hole C0017C. After washing and drilling down to $59.9 \mathrm{mbsf}$, skipping an interval of unrecoverable volcanic rubble, and recovering a failed ESCS coring attempt, Core 331-C0017D-1H was shot with the HPCS and recovered $9.5 \mathrm{~m}$ from a $9.2 \mathrm{~m}$ advance. Core 331-C0017D-2H was also shot with the HPCS, recovering $9 \mathrm{~m}$ from a $9.5 \mathrm{~m}$ advance. Core 331-C0017D-3H, however, recovered nothing from a $6.0 \mathrm{~m}$ advance, returning only a broken flapper and a cracked liner. Core 331-C0017D$4 \mathrm{H}$ likewise returned no sediment and had no advance, so we switched to the extended punch coring system (EPCS) to continue beyond 84.6 mbsf. With no recovery from a $9.5 \mathrm{~m}$ EPCS advance, we switched back to the ESCS, which returned $1.8 \mathrm{~m}$ from another advance of $9.5 \mathrm{~m}$. As the formation seemed softer, we switched back to the HPCS and gained $100 \%$ recovery from an $8.5 \mathrm{~m}$ advance into sticky mud between 103.6 and 112.1 mbsf. Switching back to the EPCS returned only a few centimeters in the core catcher from a $9.5 \mathrm{~m}$ advance, so we went back to the ESCS. This change, surprisingly, gave us two good cores (331-C0017D-9X and 10X) with 107.8\% and $68.4 \%$ recovery, respectively. However, during retrieval of Core 331-C0017D-11X, the sinker bar broke, leaving Core 11X in the hole at 149.6 mbsf. Fishing for Core $11 \mathrm{X}$ was unsuccessful because we did not have a tool onboard that would fit. The core was retrieved via a pipe trip, returning $4.8 \mathrm{~m}$ of core (50.5\% of a $9.5 \mathrm{~m}$ advance) from a depth of 140.1149.6 mbsf.

After pulling out, Hole C0017D was reentered unguided on the night of 28 September, and Core 331C0017D-12H was taken on the morning of 29 September. This final shot penetrated $1 \mathrm{~m}$ to $150.6 \mathrm{mbsf}$ but retrieved only a little gravel in the core catcher. The main reason for attempting the reentry and last core, however, was to get a temperature reading from either the advanced piston corer temperature tool (APCT3) shoe or one of the thermoseal strips taped to the inner barrel. The thermoseal strips returned a temperature measurement of $90^{\circ} \pm 5^{\circ} \mathrm{C}$ (three replicate strips), so Site C0017 ended very successfully at 150.6 mbsf with Core 331-C0017D-12H.

\section{Lithostratigraphy}

Site C0017 consists mainly of hemipelagic homogeneous mud, pumiceous sediment, and volcaniclasticpumiceous mixed sand, without the obvious hydrothermal alteration seen at previous sites. Based on sediment character and structure, major mineral composition, and the occurrence of microfossils, sediments recovered from the four holes drilled (Holes C0017A, C0017B, C0017C, and C0017D) consist of three main sediment types: hemipelagic mud, coarse angular pumiceous gravel, and volcanic sands with erosional bases. These sediments and lithologies are similar to those of Unit I encountered at Sites C0014 and C0015. However, the unaltered sedimentary sequence drilled at Site C0017 is much more vertically extensive, and subdivision may be drawn on the basis of the relative predominance of hemipelagic mud or volcaniclastic sediments. This divides the stratigraphy at Site C0017 into four units (Fig. F2; Table T2). An upper unit (Unit I), dominantly composed of hemipelagic mud from 0 to $18.5 \mathrm{mbsf}$, is underlain by two units dominated by pumiceous gravel from 19.1 to 36.2 mbsf (Unit II) and 61.1 to 78.8 mbsf (Unit III). The interval from 36.1 to 61.1 mbsf was not cored, so it was not possible to group Unit II and Unit III as a single unit, despite the strong sedimentological similarity between them. Additionally, no core was recovered in the interval 
from 78.8 to $94.3 \mathrm{mbsf}$. The deepest portion of the cored interval, from 94.3 to 144.7 mbsf (Unit IV) is dominated by hemipelagic mud. The thicknesses of individual beds of mud and gravel at Site C0017 are significantly greater than those at Site C0014, consistent with Site C0017's location on the downthrown side of a normal fault.

\section{Sediment types at Site C0017}

There is little apparent systematic vertical variation in sediment types at Site C0017. Unless stated otherwise, the following description of sediment types applies to all four lithostratigraphic units at the site.

\section{Hemipelagic mud}

Hemipelagic mud is the dominant sediment type in Unit I ( 0 to $\sim 18.5 \mathrm{mbsf}$ ) and Unit IV ( $\sim 94$ to $\sim 145$ mbsf) but also occurs in Units II and III (Fig. F2). This mud is primarily composed of hemipelagic homogeneous silty clay or clayey silt, with widely distributed foraminifers and occasional lenticular pumiceous sand patches, gravels, and mud clasts. The grayish olive to dark olive-gray color and uniformity of the mud make it easy to recognize. Foraminifers are mostly fresh and intact and are only rarely reworked, reflecting an autochthonous source. They should be useful for postcruise research that aims to establish the late Quaternary chronostratigraphy in this area and to reconstruct paleoenvironments. The relatively uniform, homogeneous, and structureless mud in the upper $18.5 \mathrm{~m}$ of sediments in Holes C0017A and C0017B (Unit I) reflects a typical hemipelagic depositional environment.

In contrast, Unit IV (Cores 331-C0017D-6X, 7H, $9 \mathrm{X}, 10 \mathrm{X}$, and $11 \mathrm{X}$; $\sim 94.3$ to $\sim 144.7 \mathrm{mbsf}$ ) comprises laminated and interbedded clay and silt and very fine sand, with homogeneous clay predominant. Layers of silt and very fine sand $(1-5 \mathrm{~cm}$ thickness) commonly form upward-fining sequences and possess erosional bases that create sharp contacts with the underlying homogeneous dark gray clay (Fig. F3). From X-ray diffraction (XRD) analyses (Table T3), the mineralogy of these silty and fine sandy layers is dominated by probably locally derived volcanic glass, quartz, and feldspar. Along with calcite, muscovite, chlorite, and dolomite, they are also the main components of the overlying and underlying homogeneous clay. These coarser grained layers are probably formed primarily by volcanic eruption and episodic gravity flows related to volcanic and seismic activity.

\section{Pumiceous gravel and lithoclast-rich horizons}

The pumiceous gravel and lithoclast-rich horizons sediment type consists of poorly sorted pumiceous sediments dominated by coarse-grained angular woody pumiceous gravels (Fig. F4). It generally has a gradational contact with finer overlying pelagic or volcaniclastic sediments but mostly sharp contacts with the underlying sediments. Pumiceous gravels predominate in Unit II (19.1-36.2 mbsf) and Unit III (61.1-78.8 mbsf) but are also found within Units I and IV. This sediment type shares similar characteristics and major mineral compositions with pumiceous sediments encountered at Site C0014, and especially Site C0015.

The pumice encountered at Site C0017 can be divided into two types: one fresh and white-gray to greenish and the other oxidized and stained yellow to brown. It has similar appearance and bulk mineralogy to that found at Site C0014. Oxidized pumice is abundant between $\sim 26$ and 35 mbsf in Hole C0017C. Occasionally, the greenish pumice gravels and clasts (Fig. F3), which are inferred to contain glauconite (Weigland et al., 2003), are mixed with oxidized fragments, which are softer and more fragile than the fresh pumice and easily broken during visual examination. The significance of the oxidized pumice is discussed in more detail in "Petrology."

\section{Volcaniclastic and pumiceous mixed sand}

Gray to black, fine to coarse sand and gravels with a mixture of volcaniclastic and pumiceous components are irregularly distributed throughout all four units at C0017 (Fig. F2). A number of individual beds show clear normal and, in one case, inverse graded bedding, generally varying from coarse sand to coarse silt. The thickness of graded beds varies from $<10 \mathrm{~cm}$ to $0.95 \mathrm{~m}$.

Volcaniclastic and pumiceous sand beds generally have sharp contacts with underlying layers but gradational contacts with overlying units, indicating a waning sediment supply. This observation is consistent with deposition from a gravity flow, probably resulting from episodic volcanic and seismic activity within and around the area, coupled with the instability of volcanic flanks in this region. The bulk mineralogy of these sediments is volcanic glass, anorthite, quartz, albite, muscovite, and trace amounts of microline and augite, based on microscopic and XRD examinations (Table T3). Shards of volcanic glass are usually brown and yellow-brown and are poorly sorted, ranging in size from coarse sand to pebbles as large as $1.2 \mathrm{~cm}$ in diameter. Vesicular structure is well 
developed on the surface of the volcanic glass shards, and pores are somewhat elongate and filled with diagenetic white minerals.

\section{Biostratigraphy}

Core catcher samples from Site C0017 yielded two zones with microfossils, a shallow one from $\sim 9$ to 28 mbsf and a deeper one from 112 to 145 mbsf (Table T4). The upper layer consists of pumice and microfossils, which are most abundant in the deeper half of this interval (at 18.5 and $27.2 \mathrm{mbsf}$ ). These two samples each possess a large fraction of $<63 \mu \mathrm{m}$ material. Foraminiferal diversity and abundance are generally consistent with surface samples from a similar pumice-foraminifer layer at Site C0014, suggesting it is a modern assemblage. Examination of wet mounts of the $<63 \mu \mathrm{m}$ material using phase contrast microscopy \pm cross-polarized light revealed good preservation of coccoliths. The assemblage was dominated by Emiliania huxleyi, Gephyrocapsa oceanica, and Reticulofenestra asanoi, highlighting a modern origin (Raffi et al., 2006; Winter and Siesser, 1994). Transport of coccoliths into the upper microfossil zone was facilitated, in part, by fecal pellets (Fig. F5). Fecal pellets and abundant centric diatoms are notable in the sample from 10.6 mbsf.

Drilling continued through a pumice-rich layer from which core recovery was poor (Table T4) before entering a second interval characterized by microfossils ( 112-138 mbsf). This deeper zone of microfossils is also characterized by a large fraction of $<63 \mu \mathrm{m}$ material. Coccoliths at these depths (E. huxleyi and $R$. asanoi) are poorly preserved and much less abundant $(<10 \%)$ than they are in the upper layer (8-28 mbsf). Foraminiferal abundances in this layer are also lower than in the upper, modern zone; however, there is a larger proportion (as high as 11\%) of benthic foramininfers in the 125 mbsf region. The large proportion of benthic foraminifers suggests the site was more favorable to benthic species in the past than it is today (i.e., hydrothermal activity may have increased at the site).

As at Site C0014, foraminifers observed in both of these layers ( 8-28 and 112-138 mbsf) are dominated by planktonic species (Table T5), suggesting a large input of planktonic foraminifers and/or that Site C0017 is a poor habitat for benthic foraminifers (Saidova, 2007), perhaps because it is still too close to the hydrothermal system. Though some fragmentation has occurred, foraminiferal preservation is generally good, with little or no evidence for dissolution and/or overgrowth; diagnostic characteristics are preserved, and many species can be identified. As at Site C0014, the abundance of Neogloboquadrina pachyderma dextral relative to the sinistrally coiled subspecies demonstrates the influence of warmer waters, presumably from the Kuroshio Current (Bandy, 1960; Ericson, 1959). Some foraminifers from 112 mbsf are pyritized (not shown), consistent with previous reports describing infilling of foraminiferal tests (Kohn et al., 1998). It should be noted that these foraminifers are poorly preserved compared with those at Site C0014 (see Figs. F11 and F12 in Expedition 331 Scientists, 2011d).

\section{Petrology}

Site C0017, which was one of the contingency sites for Expedition 331, targeted a potential recharge zone $\sim 1.5 \mathrm{~km}$ east of the principal hydrothermal field at Iheya North Knoll. Four holes were drilled within a $10 \mathrm{~m}$ radius (Fig. F1) at Site C0017, where the intervals from 0.0 to $37.3 \mathrm{mbsf}$ (Holes C0017AC0017C) and 60 to 150.7 mbsf (Hole C0017D) were cored. The four holes are considered to represent a single drilled section for purposes of petrological interpretation.

\section{Hydrothermal alteration}

The sequence drilled at Site C0017 comprises calcareous clay, volcaniclastic and foraminiferal silt and sand, and pumiceous grit and gravel (see "Lithostratigraphy"). With the exception of two intervals discussed below and the weak scattered development of green staining of pumice fragments in the upper parts of the sequence (interpreted as glauconitic "greensand," although glauconite was not identified by XRD), the extensive hydrothermal alteration seen at Sites C0013 and C0014 is almost absent in the drilled interval at Site C0017.

In Hole C0017C, the interval from 26 to $35 \mathrm{mbsf}$ (Sections 331-C0017-1H-6 through 2H-6) shows weak to moderate oxidation, similar in nature but more intense than that seen at Site C0015. Oxidation is expressed as yellow to brown coloration of clay, silt, and sand, the development of orange to brown iron oxide staining on pumice fragments (Fig. F6), and the occurrence of 1-2 $\mathrm{mm}$ orange-brown botryoidal aggregates of Fe-Si oxyhydroxides. XRD analyses of samples from this interval show similar mineral assemblages to those that were identified for unaltered material from the site (see below), with the exception that primary igneous feldspar is absent in some samples. It is likely that some degree of feldspar destruction accompanies the oxidation of the pumice. Geochemical results (see "Geochemistry") indicate that this zone of oxidation within the otherwise reduced sedimentary sequence is the result of an influx of seawater at this depth, potentially repre- 
senting recharge flow into the Iheya North hydrothermal system.

The only other visual evidence of hydrothermal alteration at Site C0017 was seen in Core 331-C0017D11X (140.2-149.7 mbsf), the deepest core from the site, which shows development of pale gray clay alteration of more permeable pumiceous grit horizons, intercalated with apparently unaltered indurated dark gray calcareous clay (Fig. F7). XRD analyses of this altered material (Table T3) identify the same quartz-glass \pm anorthite assemblage as for unaltered pumiceous horizons (consistent with the visual observation that much of the pumice retains its original texture and mineralogy), with the addition of sylvite and halite in one sample (see "Mineralogy and pore fluid chemistry," below).

The remaining sequence drilled at Site C0017 shows no visual evidence of alteration, with routine XRD identifying those phases that would be expected for a sequence of calcareous and volcaniclastic marine sediments, namely calcite, dolomite (discussed in "Mineralogy and pore fluid chemistry," below), quartz, feldspar, muscovite, chlorite, and volcanic glass (Table T3). Halite is also commonly detected using XRD in samples from below $\sim 25 \mathrm{mbsf}$, but it is possible that this may be due to seawater contamination from drilling.

\section{Sulfide mineralization}

When compared with Sites C0013 and C0014, the drilled interval at Site C0017 is notable for the absence of sulfide mineralization at shallow depth. Pyrite was only observed consistently at depths below 94 mbsf in Hole C0017D. In these deeper portions of the sequence, pyrite occurs in trace quantities as very fine grained disseminations and as rare scattered 1-3 $\mathrm{mm}$ aggregates with quartz and occasional discontinuous millimeter-scale bands or veins within indurated clay sediment.

\section{Mineralogy and pore fluid chemistry}

Site C0017 is the only location cored during Expedition 331 where dolomite is present in sediments (it also occurs in anhydrite nodules at Site C0013). At Site C0017, the occurrence of dolomite is limited to two discrete depth intervals (Table T3): 10-20 mbsf in Holes C0017B and C0017C and 110-140 mbsf in Hole C0017D. These intervals correlate well with intervals of low-Mg, high-alkalinity pore fluids (Figs. F8, F9; see "Geochemistry").

The detection of the evaporitic minerals sylvite $(\mathrm{KCl})$ and halite at 143 mbsf in Sample 331-C0017D-11X-3, $27-29 \mathrm{~cm}$, also correlates well with the pore water chemistry, corresponding to a sharp increase in dis- solved K at that depth (Fig. F8; see "Geochemistry").

\section{Geochemistry}

\section{Interstitial water}

A total of 21 whole-round samples were processed at Site C0017 from four different holes (Table T6). Many samples were collected immediately above or below whole rounds dedicated for microbiology; however, there were more whole rounds collected for interstitial water analyses than for microbiology at this site. We squeezed whole rounds at the laboratory temperature of $\sim 20^{\circ} \mathrm{C}$ rather than at in situ temperature. More than half of the samples are from Hole C0017D, from 63 to 141 mbsf.

\section{Major and minor cations and anions}

$\mathrm{Na}$ concentrations (Fig. F8) are nearly constant with depth, whereas $\mathrm{Cl}$ (Fig. F10) increases, yielding a small decrease in $\mathrm{Na} / \mathrm{Cl}$ in Hole C0017D relative to the shallower holes. Potassium is generally above seawater concentrations in the uppermost 10-20 mbsf, probably because of irreversible ion exchange with clays, but it decreases to below seawater values below $\sim 70$ mbsf and then increases again to seawater concentration in the bottommost $10 \mathrm{~m}$ of Hole C0017D. The decrease likely results from uptake into alteration minerals at low temperature, but the increase requires a source of potassium near the bottom of the hole. One possible source is dissolution of sylvite $(\mathrm{KCl})$, which was reported in the core at 143 mbsf (see "Mineralogy and pore fluid chemistry"). A second possible source is lateral incursion of a Krich solution at this depth, which could be either seawater or a high-temperature hydrothermal solution. Seawater incursion would increase $\mathrm{K}$ but would also increase $\mathrm{Mg}$ and lower $\mathrm{Ca}$, and neither of these changes is observed; a hydrothermal solution therefore seems more likely. Enrichments in $\mathrm{Ca}$ at depth are consistent with sediment alteration and release of $\mathrm{Ca}$ to the pore water. $\mathrm{Mg}$ is slightly depleted in both the upper and lower $20 \mathrm{~m}$ of the hole. These slight depletions coincide with the presence of dolomite in the corresponding intervals, at 10-20 and 110-140 mbsf (Table T3). Distributions of $\mathrm{B}, \mathrm{Li}$, and $\mathrm{Sr}$ are likewise consistent with low-temperature weathering deep in the sequence (Fig. F11). Like $\mathrm{K}, \mathrm{Li}$ is higher than in seawater within the uppermost 20 mbsf.

\section{Sulfate, alkalinity, ammonium, phosphate, and silicon}

Sulfate displays a minimum concentration at 15 mbsf (Fig. F10) that roughly coincides with maxima in alkalinity, ammonium, phosphate, and Si at 11- 
15 mbsf (Fig. F9) and likely results from sulfate reduction coupled with oxidation of organic matter in the sediments. Sulfate increases again to slightly in excess of seawater concentration below 15 mbsf and is roughly uniform at greater depth, with some scatter. As interpreted in "Petrology," the increase in sulfate at $\sim 25 \mathrm{mbsf}$, along with the accompanying decreases in alkalinity, ammonium, phosphate, manganese, and silicon, almost certainly results from lateral intrusion of unaltered ocean bottom water into the sediment at $\sim 30$ mbsf. Below this zone of seawater intrusion, phosphate remains low. Alkalinity exhibits some structure below 50 mbsf, increasing significantly below $\sim 75$ mbsf, probably because of low-temperature alteration reactions. Silica generally decreases with depth, suggesting some uptake into authigenic minerals and/or a second deep zone of seawater recharge. This constituent scatters about concentrations that are lower than those found at Sites C0013 and C0014 (Fig. F9).

\section{Summary}

The uppermost 25-35 $\mathrm{m}$ at Site C0017 is characterized by organic matter diagenesis in the upper half and intrusion of seawater in the lower half. Below $\sim 50$ mbsf, this site is characterized by low-temperature alteration reactions and considerable scatter in the pore water data, probably resulting from interaction between chemical and hydrologic processes. The shape of the temperature profile indicates overall downwelling at Site C0017, with irregularities suggestive of nonsteady-state processes including lateral flow. The temperature gradient increases from 70 to 80 mbsf, becomes nearly flat at $85-110 \mathrm{mbsf}$, and increases again to $90^{\circ} \mathrm{C}$ at the bottom of the hole (see "Physical properties"), suggesting a complex three-dimensional hydrologic regime on which are superimposed the effects of temperature-dependent water-rock reactions.

\section{Headspace gas analysis}

Methane concentrations (Fig. F12) are quite low, mostly $<1 \mu \mathrm{M}$. The highest values are near the bottom of the deepest Hole C0017D, where a mean value of $1.8 \mu \mathrm{M}$ was found between 112 and 141 mbsf. The highest concentration is $3.4 \mu \mathrm{M}$ at 112 mbsf. Methane measured in safety gas (Table T7) and science gas samples (Table T8) shows similar trends, but science gas analyses had a higher detection limit because the gas chromatograph used shows a large nitrogen peak near the methane peak. Science gas samples are thus mostly below detection, except for samples at $\sim 137$ mbsf, which show $1-2 \mu \mathrm{M}$ methane. We conclude that methanogensis is not a robust metabolism at Site C0017. The small concentration of methane in pore water from deep horizons (112-137 mbsf) may be hydrothermal in origin or it may result from methanogenesis occurring deep at this site.

Hydrogen was not observed except for small peaks at six horizons scattered down the sediment column (Table T8).

\section{Sediment carbon, nitrogen, and sulfur composition}

Calcium carbonate $\left(\mathrm{CaCO}_{3}\right)$ content calculated from inorganic carbon concentration ranges from 44.77 $\mathrm{wt} \%$ to below the detection limit $(<0.001 \mathrm{wt} \%)$ (Table T9; Fig. F13). High concentrations ( $>5 \mathrm{wt} \%)$ were observed at depths above $25 \mathrm{mbsf}$, where the sediment is mostly hemipelagic clay containing foraminiferal shells (see "Lithostratigraphy"). The highest $\mathrm{CaCO}_{3}$ contents (>40 wt $\%$ ) were observed in calcareous sand and sandy clay layers, which contain a large amount of foraminiferal shells. $\mathrm{CaCO}_{3}$ contents are low at 25$80 \mathrm{mbsf}$, where the sediment is mostly pumiceous gravel. $\mathrm{CaCO}_{3}$ averages $6 \mathrm{wt} \%$ below $95 \mathrm{mbsf}$, where the sediment is hemipelagic clay with sandy layers, the same lithology as that within the uppermost $25 \mathrm{~m}$.

Total organic carbon (TOC) content ranges from 0.01 to $0.96 \mathrm{wt} \%$ (Fig. F14). High concentrations ( $>0.5$ wt\%) were observed at depths above 25 mbsf, although layers of volcaniclastic sand within this depth interval have low concentrations ( 0.1 to $\sim 0.3$ $\mathrm{wt} \%)$. TOC content is generally low $(<0.1 \mathrm{wt} \%)$ in pumiceous sediments between 25 and 80 mbsf. Below 95 mbsf, it averages $0.3 \mathrm{wt} \%$. Total nitrogen (TN) ranges from below the detection limit $(<0.001 \mathrm{wt} \%)$ to $0.11 \mathrm{wt} \%$. TN is higher in the hemipelagic sediment at $0-25$ and below 95 mbsf than it is in pumiceous sediments between 25 and 95 mbsf. The ratio of TOC to TN $(\mathrm{C} / \mathrm{N})$ in hemipelagic sediments is generally larger than the Redfield ratio of 6.6, indicating an organic origin for nitrogen. Values smaller than the Redfield ratio, especially in pumiceous sediments, indicate that some portion of $\mathrm{TN}$ is inorganic.

Total sulfur (TS) content ranges from 0.03 to $0.7 \mathrm{wt} \%$. TS is generally low $(<0.2 \mathrm{wt} \%)$ in the pumiceous sediment between 25 and 80 mbsf. Total sulfur is lower at Site C0017 than at Sites C0013, C0014, and C0016, where significant amounts of hydrothermal sulfide and sulfate were observed.

\section{Microbiology Total prokaryotic cell counts}

The abundance of microbial cells in subseafloor sediments at Site C0017 was evaluated by fluorescent microscopy using SYBR Green I as a fluorochrome dye. 
Maximum cell numbers were observed at $6.36 \mathrm{mbsf}$ $\left(3.2 \times 10^{7}\right.$ cells $\left./ \mathrm{mL}\right)$, and cell numbers range from 2.4 $\times 10^{7}$ to $3.2 \times 10^{7}$ cells $/ \mathrm{mL}$ at depths above 10.8 mbsf. Microbial cell counts irregularly decrease with depth (Fig. F15; Table T10). Below 50 mbsf, cell counts decrease to less than the limit of detection of $\sim 1 \times 10^{6}$ to $4 \times 10^{6}$ cells $/ \mathrm{mL}$.

\section{Cultivation of thermophiles}

Growth of Thermococcales (e.g., Thermococcus) at $80^{\circ} \mathrm{C}$ and Aquificales (e.g., Persephonella) and thermophilic Epsilonproteobacteria (e.g., Nitratiruptor) at $55^{\circ} \mathrm{C}$ was examined for cores from a high-temperature zone below 94.7 mbsf. No growth of thermophiles was observed on board.

\section{Contamination tests}

Fluorescent microspheres and perfluorocarbon tracer (PFT) were used to test for contamination (Tables T11, T12). The PFT test suggests that even in sediment layers containing large amounts of pumice, contamination by drilling fluid was quite low. This was the case even at the outer surface of the core and even with larger grain sizes, which have the greatest risk of contamination. We found evidence for contamination by drilling fluid in the interior of cores obtained from Hole C0017D by the ESCS, but detected PFT concentrations were much lower than those in the drilling mud fluid collected from the onboard tank and that adhering to the massive sulfide of Site C0016 (Table T12; see Table T8 in Expedition 331 Scientists, 2011b, and Table T6 in Expedition 331 Scientists, 2011f).

\section{Cultivation of iron-oxidizing bacteria}

The depth interval from 26 to 35 mbsf at Site C0017 probably represents a zone of recharge flow in this hydrothermal system, as suggested by the temperature and pore water chemistry profiles (see "Petrology" and "Geochemistry"). It looks to be heavily oxidized, by either biotic or abiotic means. The interaction of infiltrating cold seawater with the surrounding reduced layers would produce a redox boundary that can be utilized by many microorganisms, including iron-oxidizing bacteria. For this reason we targeted this oxidized interval for FeOB cultivation experiments (Table T13). Samples 331C0017C-1H-7, $1 \mathrm{~cm}$, and $1 \mathrm{H}-7,2 \mathrm{~cm}$, are two subsamples from the same whole round, but the latter is more rust-colored and appears to be more oxidized.

After 4.5 days of growth, samples from the top of this depth interval, in a section of iron oxide-stained pumice fragments at 26.26-28.45 mbsf, showed significant growth in artificial seawater (ASW) media A (microaerophilic). The preference of these microbes for a microaerophilic environment agrees with the identification of this layer as a zone of recharge flow (oxygenated seawater). Above this layer, outside of the oxidized zone, little to no growth of $\mathrm{FeOB}$ was observed. Below this layer, where the sediments transition from yellow-to-brown clay, silt, and sand (see "Petrology"), there was also no growth, suggesting a FeOB preference for growth where there is less finegrained material.

Observations of putative FeOB cellular morphology were similar to those from other sites from Expedition 331. These include $\sim 1.5 \mu \mathrm{m}$ rod-shaped cells associated with small particles (Fig. F16A, F16B, F16E, F16F) in addition to large aggregates of cells colonizing larger particles (possibly iron oxides; Fig. F16G, F16H). Of particular importance are the two cells localized on the end of a stalklike structure (Fig. F16C, F16D). Though difficult to see because of the angle of observation, moving up and down through the plane of focus showed that these cells were on opposite sides of a stalk jutting out of the top of the larger particle. This is the first observation of a putative bifurcated iron oxide twisted stalk with attached cells in any of the incubations viewed during the expedition.

Contamination tests from Site C0017 (Tables T11, T12) reveal that all samples that showed growth also exhibited some level of contamination. For Section 331-C0017C-1H-7, contamination was below detection after counting 100 fields, though a single bead was seen upon cursory examination. This may be due to a cracked core liner for that section allowing washout to have occurred. Section 331-C0017C-1H-6 was taken after this core was split and was not tested for contamination, though it came from an intact internal location within the core. Overall, caution must still be exercised when considering whether these Site C0017 enrichments represent FeOB originating from in situ locations.

In an attempt to test whether biotic iron oxidation was occurring in situ at depth, the original sample used to inoculate the enrichment for Section 331C0017C-1H-7 was dried and imaged using the scanning electron microscope (SEM) and analyzed with energy dispersive spectrometry (EDS) to test for the presence of putative iron oxide filaments of biotic origin. As the doubling time for FeOB is $\sim 12 \mathrm{~h}$ (Emerson et al., 2007), these filaments would not have had time to form as the core was brought on deck. SEM results show a number of patches of iron and iron oxide filaments, many located within protected cavities of pumice fragments. Photos were taken of filaments within these cavities (Fig. F17A, F17B), which may explain the lack of a significant oxygen peak in 
the EDS spectrum. Figure F17C is the only EDS spectrum that has a significant oxygen peak; however, because of the low ratio of oxygen to iron, an iron oxyhydroxide (FeOOH) filament is improbable as compared to other marine $\mathrm{FeOB}$ (Emerson and Moyer, 2002; Emerson et al., 2007). Though it is possible that all three of these iron/iron oxide filament patches are of biotic origin, this evidence is not conclusive. Further testing must be conducted onshore.

\section{Conclusions}

Site C0017 is located in a probable seawater recharge area in the Iheya North field. Significant impacts of hydrothermal fluids were not observed in geochemical profiles and sediment alteration, except for localized oxidation (see "Geochemistry" and "Lithostratigraphy"). The temperature at the bottom of the deepest Hole C0017D at $151 \mathrm{mbsf}$ is $90^{\circ} \mathrm{C}$. We have thus had an opportunity to observe subseafloor microbial communities likely supported by buried organic matter, over a considerable range of temperature.

Relatively low microbial abundance compared with previous Ocean Drilling Program/IODP sites on continental margins (Parkes et al., 1994, 2000; D'Hondt et al., 2004) was seen at Site C0017 (as many as $3.2 \times$ $10^{7}$ cells $/ \mathrm{mL}$ ), as was also the case at Site C0015 (as many as $1.2 \times 10^{7}$ cells $/ \mathrm{mL}$ ). Cell abundance at Site C0017 may also be depressed as a result of the generally low levels of organic carbon available in the subseafloor sediments around the Iheya North field (see "Microbiology" and "Geochemistry," both in Expedition 331 Scientists, 2011e). At Site C0017, effects of lithology on cell abundance were again observed, as at Site C0015, where a relatively abundant microbial biomass was observed in samples with pumiceous sands and gravels. (Compare, for example, cell counts in the pumiceous sample from $10.8 \mathrm{mbsf}$ in Hole C0017B with that in the hemipelagic mud sample from $14.8 \mathrm{mbsf}$ ) (Table T10). As is usually the case (Parkes et al., 1994, 2000), the subseafloor microbial abundance generally decreases with depth (Fig. F15). Lithostratigraphy at Site C0017 consists of diverse units such as hemipelagic mud and clay, pumiceous sediment, and volcaniclastic-pumiceous mixed sand (see "Lithostratigraphy"). Cell abundances are strongly influenced by this lithological variation and its effect on porosity and pore space size, as seen in previous studies (Schmidt et al., 1998; Zhang et al., 1998; Parkes et al., 2000; Inagaki et al., 2003; Rebata-Landa and Santamarina, 2006), as well as by geochemical constraints imposed by seawater recharge.

Though contamination cannot be ruled out, enrichment experiments represent the deepest successful
FeOB enrichments to date in a marine environment and could lend insight into the colonization of lowtemperature hydrothermal systems via recharge zone flow.

\section{Physical properties}

Physical property measurements were made at Site C0017 to nondestructively characterize lithological units and states of sediment consolidation. In the following discussion, the four holes at Site C0017 (Holes C0017A, C0017B, C0017C, and C0017D) are treated as one continuous depth profile.

\section{Density and porosity}

Bulk density at Site C0017 was determined from both gamma ray attenuation (GRA) measurements on whole cores (with the multisensor core logger for whole-round samples [MSCL-W]) and moisture and density (MAD) measurements on discrete samples (see "Physical properties" in Expedition 331 Scientists, 2011b). A total of 70 discrete samples were analyzed for $\operatorname{MAD}(7,9,14$, and 40 from Holes C0017A, C0017B, C0017C, and C0017D, respectively). Wet bulk density is roughly constant with depth to $\sim 20$ mbsf (Holes C0017A and C0017B) (Fig. F18; Table T14), as determined by both MAD and GRA, although the latter values are generally lower than the former and exhibit more scatter than previous sites. The average bulk density in Holes C0017A and $\mathrm{C} 0017 \mathrm{~B}$ is $\sim 1.59 \mathrm{~g} / \mathrm{cm}^{3}$. Between 20 and $60 \mathrm{mbsf}$ (Hole C0017C), bulk density decreases somewhat from $\sim 1.7$ to $1.3 \mathrm{~g} / \mathrm{cm}^{3}$. In Hole C0017D, bulk density is relatively constant from 60 to $80 \mathrm{mbsf}\left(\sim 1.5 \mathrm{~g} / \mathrm{cm}^{3}\right)$ and then increases to $\sim 1.9 \mathrm{~g} / \mathrm{cm}^{3}$ between 80 and 147 mbsf.

Grain density was calculated from discrete MAD measurements and is also approximately constant $\left(2.6 \pm 0.2 \mathrm{~g} / \mathrm{cm}^{3}\right)$ between 0 and $80 \mathrm{mbsf}$ (data not shown). Grain density is slightly lower than average in the depth range from $\sim 30$ to 80 mbsf.

Porosity was calculated from MAD measurements. It is generally quite high $(\sim 60 \%)$ and mirrors patterns of bulk density. It is relatively constant in Holes C0017A and C0017B; it increases somewhat between 20 and $\sim 80$ mbsf (Hole C0017C and the upper part of Hole C0017D) and then decreases steadily toward values between $20 \%$ and $30 \%$ at the bottom of Hole C0017D ( 147 mbsf) (Fig. F19; Table T14).

Density and porosity results from the four holes at Site C0017 reflect the basic lithology of the hole. In the uppermost $20 \mathrm{~m}$, sediments are predominantly clays with some sand and pumice; between 20 and 80 mbsf is a higher incidence of pumice and corre- 
spondingly lower bulk density. From 95 to $145 \mathrm{mbsf}$, sediments are again dominated by clays and the density increases. At finer scales in the clay-dominated sections, GRA-derived density and MSCL-derived $P$ wave velocities exhibit small changes that reflect changes from finer grained clays to somewhat coarser grained silty clays (see " $\boldsymbol{P}$-wave velocity and anisotropy measurements").

\section{Electrical resistivity (formation factor)}

Formation factor is a measure of the connected pore space within sediment and is used to calculate the bulk sediment diffusion coefficient. Electrical impedance measurements were made at 87 depths $(13,14$, 13, and 47 measurements in Holes C0017B, C0017C, C0017D, and C0017E, respectively). Formation factors calculated for Hole C0017 are near 3 in the uppermost 30 mbsf (Holes C0017A and C0017B); values increase with depth and are generally between $\sim 5$ and 8 (Fig. F20). Several peaks in formation factor generally occur where sediment water content is lower (bulk density is higher), but the peaks are not clearly related to any lithostratigraphic control and may be measurement artifacts.

\section{P-wave velocity and anisotropy measurements}

$P$-wave velocity and relative anisotropy were measured on discrete samples indurated enough to cut sample polyhedrons. This was rarely the case. MSCLderived $P$-wave velocities generally increase with depth in the core as sediments become more compacted (Fig. F21). It is not always clear from the lithology what causes some of the larger peaks in $P$ wave velocity; however, small-scale variations often correlate with changes in grain size and density.

\section{Thermal conductivity}

Thermal conductivity was measured on whole-round cores. A total of 88 measurements were made $(13,15$, 14, and 46 measurements from Holes C0017A, C0017B, C0017C, and C0017D, respectively). Average thermal conductivity in Holes C0017A and $\mathrm{C} 0017 \mathrm{~B}$ is $\sim 1 \mathrm{~W} /(\mathrm{m} \cdot \mathrm{K})$. Between 20 and $60 \mathrm{mbsf}$ (Hole C0017C), thermal conductivity decreases somewhat sharply from $\sim 1$ to $0.3 \mathrm{~W} /(\mathrm{m} \cdot \mathrm{K})$. In Hole C0017D it increases from $\sim 0.5 \mathrm{~W} /(\mathrm{m} \cdot \mathrm{K})$ at $65 \mathrm{mbsf}$ to $1.5 \mathrm{~W} /(\mathrm{m} \cdot \mathrm{K})$ between 120 and $140 \mathrm{mbsf}$ (Fig. F22). Average thermal conductivity for all four holes is $1.09 \pm 0.3 \mathrm{~W} /(\mathrm{m} \cdot \mathrm{K})$. Thermal conductivity is loosely and inversely correlated with porosity. As porosity decreases, thermal conductivity increases as water is forced from void spaces, because the thermal conductivity of grains is greater than that of water.

\section{In situ temperature}

In situ temperature was measured using the APCT3 (six of eight measurements were successful, at 18$112 \mathrm{mbsf}$ ) and thermoseal strips (one measurement at 151 mbsf) (Table T15; Fig. F23). For the APTC3, all temperature-time series were recorded at $1 \mathrm{~s}$ intervals. The APCT3 stopped at the mudline for as long as 10 min prior to each penetration, yielding eight measurements of bottom water temperature that averaged $4.87^{\circ} \pm 0.51^{\circ} \mathrm{C}(1 \sigma)$. This range indicates that strong bottom water temperature variation exists, spatially, temporally, or both. Temperature-time series for each measurement are shown in Figure F24. Temperature records show significant frictional heating as the coring shoe penetrated the sediment, followed by subsequent temperature decay toward the in situ value. For most of the measurements, the probe was kept in the sediment for $>5 \mathrm{~min}$, allowing accurate extrapolation to equilibrium formation temperature based on a 1/time approximation (Table T15). Most measurements exhibit good penetration heating and initial decay curves, with two exceptions: Core 331-C0017D-4H at 84.7 mbsf, which did not have good penetration, and Core $12 \mathrm{H}$ at 150.7 mbsf, where recorded temperatures are greater than the calibrated maximum temperature for the APCT3 tool $\left(55^{\circ} \mathrm{C}\right)$. Mathematical fits to the temperaturetime series are also good and yield the equilibrium formation temperatures that are plotted versus depth in Figure F23. The deepest measurement at 150.7 mbsf was determined from three replicate thermoseal strips, with beads calibrated to blacken when exposed to temperatures of $75^{\circ}, 80^{\circ}, 85^{\circ}, 90^{\circ}$, and $95^{\circ} \mathrm{C}$. The first four beads were blackened on two of the strips, indicating exposure to a temperature between $90^{\circ}$ and $95^{\circ} \mathrm{C}$, and the first three beads were blackened on the third strip indicating a temperature between $85^{\circ}$ and $90^{\circ} \mathrm{C}$. We report this temperature somewhat conservatively as $90^{\circ} \pm 5^{\circ} \mathrm{C}$.

Temperature and thermal conductivity at Site C0017 vary from one lithological unit to another (Fig. F24). Three broad units can be defined: from the top to 60 mbsf (Unit I), from 60 to 100 mbsf (Unit II), and from 100 mbsf to the bottom (Unit III). These correspond roughly with the upper clay layers, the middle pumice-rich layers, and the hard, indurated clay layers defined by the MAD data and the lithostratigraphy results.

\section{Heat flow}

If heat transfer proceeds via conduction and heat flow is constant, the thermal gradient is inversely proportional to thermal conductivity according to Fourier's law (Expedition 331 Scientists, 2011b). Heat flow was estimated using the mean thermal 
conductivity derived for each unit (I, II, and III) (Table T16). Values increase by roughly a factor of 10 within each unit.

\section{MSCL-I and MSCL-C imaging}

MSCL-derived core images and color analyses are presented in the visual core descriptions (VCDs).

\section{MSCL-W derived electrical resistivity}

MSCL-W based resistivity data at this site are generally low $(<4 \Omega \mathrm{m})$, but there are regions of high resistivity at $\sim 37 \mathrm{mbsf}(5-30 \Omega \mathrm{m})$ and at 95 and $140 \mathrm{mbsf}$ (10-20 $\Omega \mathrm{m})$. There is no obvious relationship with the discrete measurements of formation factor (Fig. F25 versus Fig. F20).

\section{References}

Bandy, O.L., 1960. The geologic significance of coiling ratios in the foraminifer Globigerina pachyderma (Ehrenberg). J. Paleontol., 34(4):671-681. http://jpaleontol.geoscienceworld.org/cgi/content/abstract/34/4/ 671

D'Hondt, S., Jørgensen, B.B., Miller, D.J., Batzke, A., Blake, R., Cragg, B.A., Cypionka, H., Dickens, G.R., Ferdelman, T., Hinrichs, K.-U., Holm, N.G., Mitterer, R., Spivack, A., Wang, G., Bekins, B., Engelen, B., Ford, K., Gettemy, G., Rutherford, S.D., Sass, H., Skilbeck, C.G., Aiello, I.W., Guerin, G., House, C.H., Inagaki, F., Meister, P., Naehr, T., Niitsuma, S., Parkes, R.J., Schippers, A., Smith, D.C., Teske, A., Wiegel, J., Naranjo Padillo, C., and Solis Acosta, J.L., 2004. Distributions of microbial activities in deep subseafloor sediments. Science, 306(5705):22162221. doi:10.1126/science.1101155

Emerson, D., and Moyer, C.L., 2002. Neutrophilic Fe-oxidizing bacteria are abundant at the Loihi Seamount hydrothermal vents and play a major role in Fe oxide deposition. Appl. Environ. Microbiol., 68(6):3085-3093. doi:10.1128/AEM.68.6.3085-3093.2002

Emerson, D., Rentz, J.A., Lilburn, T.G., Davis, R.E., Aldrich, H., Chan, C., and Moyer, C.L., 2007. A novel lineage of Proteobacteria involved in formation of marine Fe-oxidizing microbial mat communities. PLoS ONE, 2(8):e667. doi:10.1371/journal.pone.0000667

Ericson, D.B., 1959. Coiling direction of Globigerina pachyderma as a climatic index. Science, 130(3369):219-220. doi:10.1126/science.130.3369.219

Expedition 331 Scientists, 2011a. Expedition 331 summary. In Takai, K., Mottl, M.J., Nielsen, S.H., and the Expedition 331 Scientists, Proc. IODP, 331: Tokyo (Integrated Ocean Drilling Program Management International, Inc.). doi:10.2204/iodp.proc.331.101.2011

Expedition 331 Scientists, 2011b. Methods. In Takai, K., Mottl, M.J., Nielsen, S.H., and the Expedition 331 Scientists, Proc. IODP, 331: Tokyo (Integrated Ocean Drilling Program Management International, Inc.). doi:10.2204/iodp.proc.331.102.2011
Expedition 331 Scientists, 2011c. Site C0013. In Takai, K., Mottl, M.J., Nielsen, S.H., and the Expedition 331 Scientists, Proc. IODP, 331: Tokyo (Integrated Ocean Drilling Program Management International, Inc.). doi:10.2204/iodp.proc.331.103.2011

Expedition 331 Scientists, 2011d. Site C0014. In Takai, K., Mottl, M.J., Nielsen, S.H., and the Expedition 331 Scientists, Proc. IODP, 331: Tokyo (Integrated Ocean Drilling Program Management International, Inc.). doi:10.2204/iodp.proc.331.104.2011

Expedition 331 Scientists, 2011e. Site C0015. In Takai, K., Mottl, M.J., Nielsen, S.H., and the Expedition 331 Scientists, Proc. IODP, 331: Tokyo (Integrated Ocean Drilling Program Management International, Inc.). doi:10.2204/iodp.proc.331.105.2011

Expedition 331 Scientists, 2011f. Site C0016. In Takai, K., Mottl, M.J., Nielsen, S.H., and the Expedition 331 Scientists, Proc. IODP, 331: Tokyo (Integrated Ocean Drilling Program Management International, Inc.). doi:10.2204/iodp.proc.331.106.2011

Inagaki, F., Suzuki, M., Takai, K., Oida, H., Sakamoto, T., Aoki, K., Nealson, K.H., and Horikoshi, K., 2003. Microbial communities associated with geological horizons in coastal subseafloor sediments from the Sea of Okhotsk. Appl. Environ. Microbiol., 69(12):7224-7235. doi:10.1128/AEM.69.12.7224-7235.2003

Kohn, M.J., Riciputi, L.R., Stakes, D., and Orange, D.L., 1998. Sulfur isotope variability in biogenic pyrite: reflections of heterogeneous bacterial colonization? Am. Mineral., 83(11-12):1454-1468. http://www.minsocam.org/msa/ammin/TOC/Articles_Free/1998/ Kohn_p1454-1468_98.pdf

Parkes, R.J., Cragg, B.A., Bale, S.J., Getliff, J.M., Goodman, K., Rochelle, P.A., Fry, J.C., Weightman, A.J., and Harvey, S.M., 1994. Deep bacterial biosphere in Pacific Ocean sediments. Nature (London, U. K.), 371(6496):410-413. doi:10.1038/371410a0

Parkes, R.J., Cragg, B.A., and Wellsbury, P., 2000. Recent studies on bacterial populations and processes in subseafloor sediments: a review. Hydrogeol. J., 8(1):11-28. doi:10.1007/PL00010971

Raffi, I., Backman, J., Fornaciari, E., Pälike, H., Rio, D., Lourens, L., and Hilgen, F., 2006. A review of calcareous nannofossil astrobiochronology encompassing the past 25 million years. Quat. Sci. Rev., 25(23-24):3113-3137. doi:10.1016/j.quascirev.2006.07.007

Rebata-Landa, V., and Santamarina, J.C., 2006. Mechanical limits to microbial activity in deep sediments. Geochem., Geophys., Geosyst., 7(11):Q11006-Q11017. doi:10.1029/ 2006GC001355

Saidova, K.M., 2007. Benthic foraminiferal assemblages of the South China Sea. Oceanology, 47(5):653-659. doi:10.1134/S0001437007050074

Schmidt, J.L., Deming, J.W., Jumars, P.A., and Keil, R.G., 1998. Constancy of bacterial abundance in surficial marine sediments. Limnol. Oceanogr., 43(5):976-982. doi:10.4319/lo.1998.43.5.0976

Weigland, P.W., Matthews, V., III, Cornelius, S., and Talbot, J., 2003. Origin of green color in lapilli tuff from the Pinnacles Volcanic Formation, California. Geol. Soc. Am. 
Abstr. Progr., 35(6):579. http://gsa.confex.com/gsa/ 2003AM/finalprogram/abstract_64025.htm

Winter, A., and Siesser, W.G., 1994. Atlas of living coccolithophores. In Winter, A., and Siesser, W.G. (Eds.), Coccolithophores: Cambridge (Cambridge Univ. Press), 107159.

Zhang, C., Palumbo, A.V., Phelps, T.J., Beauchamp, J.J., Brockman, F.J., Murray, C.J., Parsons, B.S., and Swift,
D.J.P., 1998. Grain size and depth constraints on microbial variability in coastal plain subsurface sediments.

Geomicrobiol. J., 15(3):171-185. doi:10.1080/

01490459809378074

Publication: 4 October 2011

MS 331-107 
Figure F1. Bathymetric map, Site C0017.

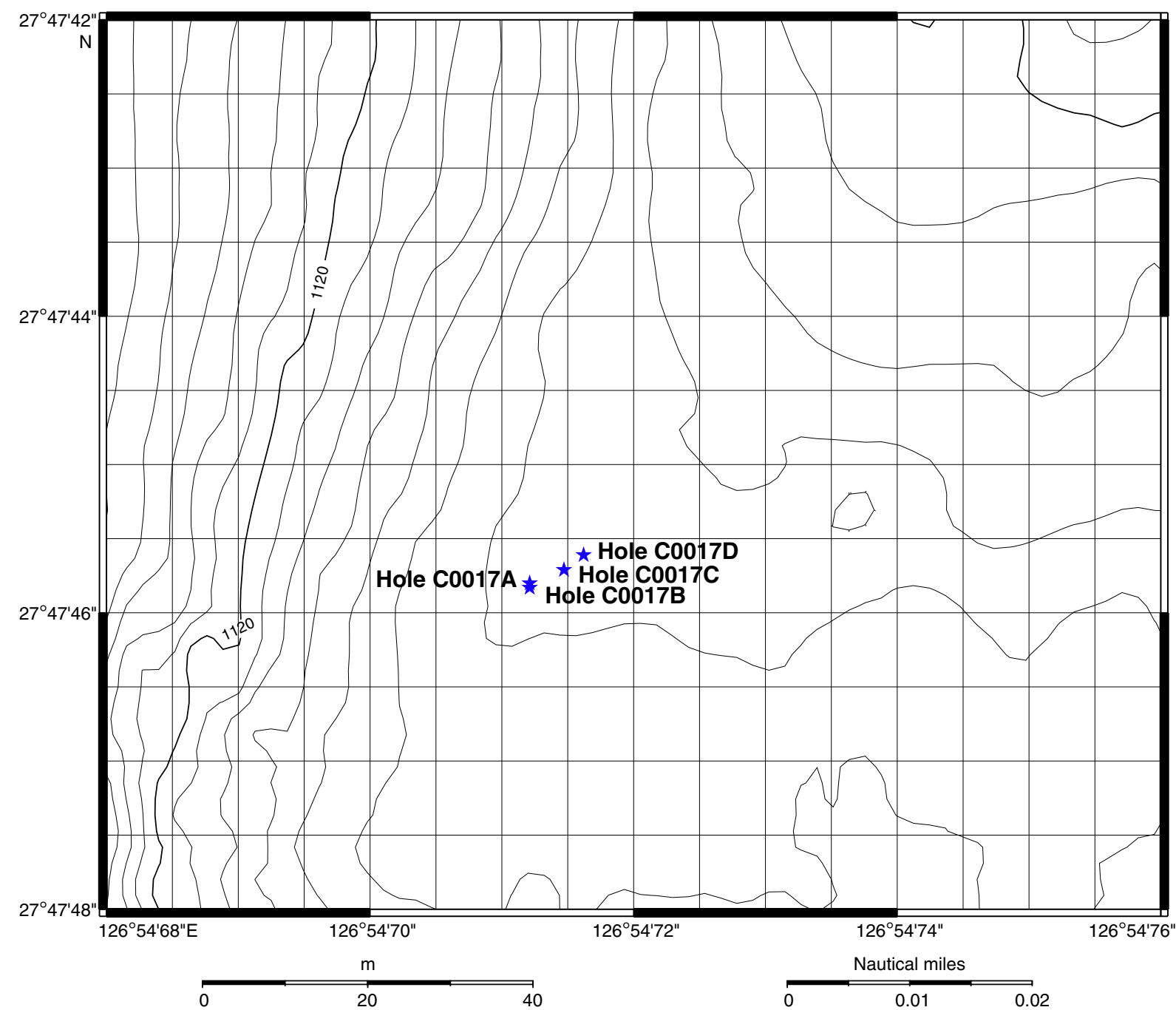


Figure F2. Sedimentary log for Site C0017, showing sediment types and lithological units, as defined in the text.

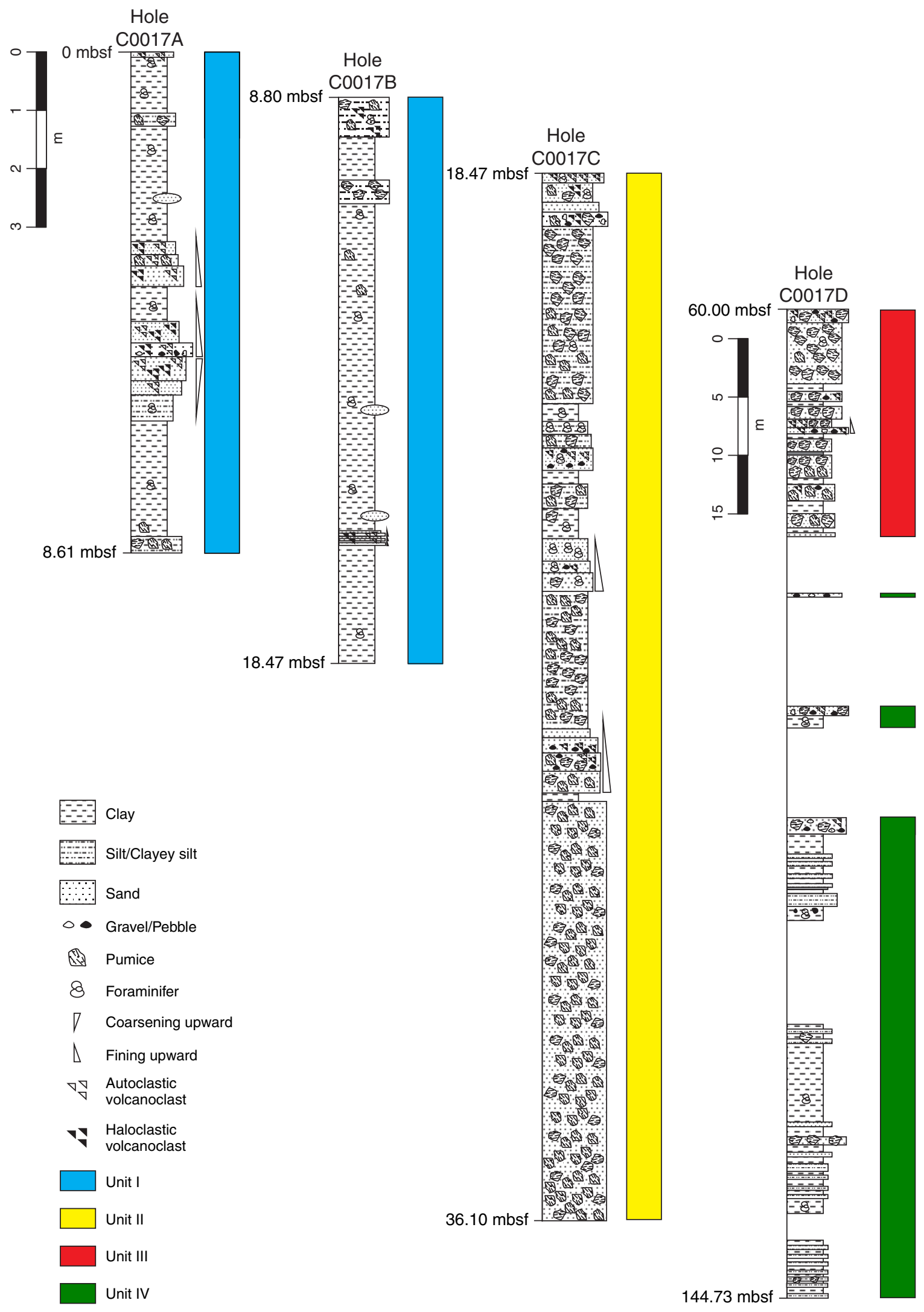


Figure F3. A. Core photograph showing contacts between interbedded sandstone and shale (interval 331C0017A-1H-4, 78-119 cm). Note presence of rip-up mud units in overlying sand. (Continued on next page.)

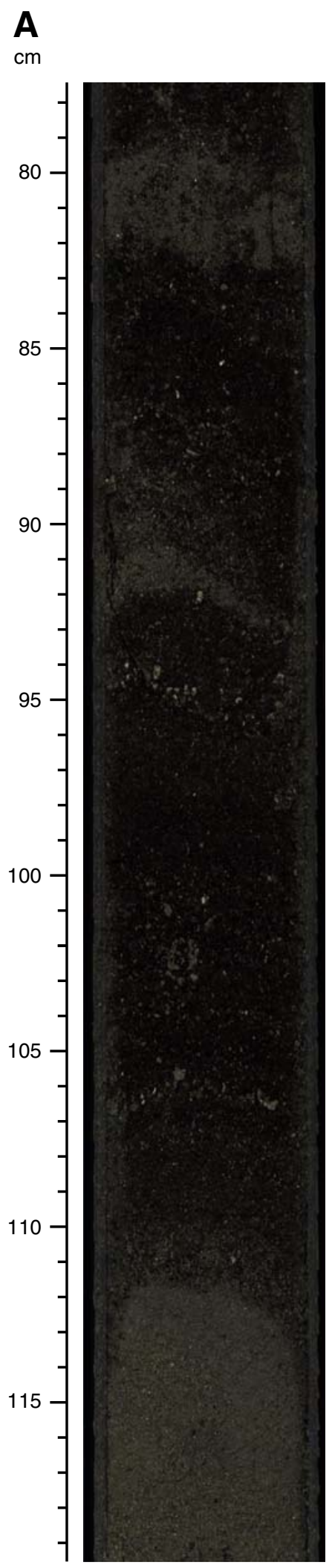


Figure F3 (continued). B. Core photograph showing sharp erosional contact between sand and mud unit at $72 \mathrm{~cm}$ (interval 331-C0017C-1H-4, 54-80 cm).

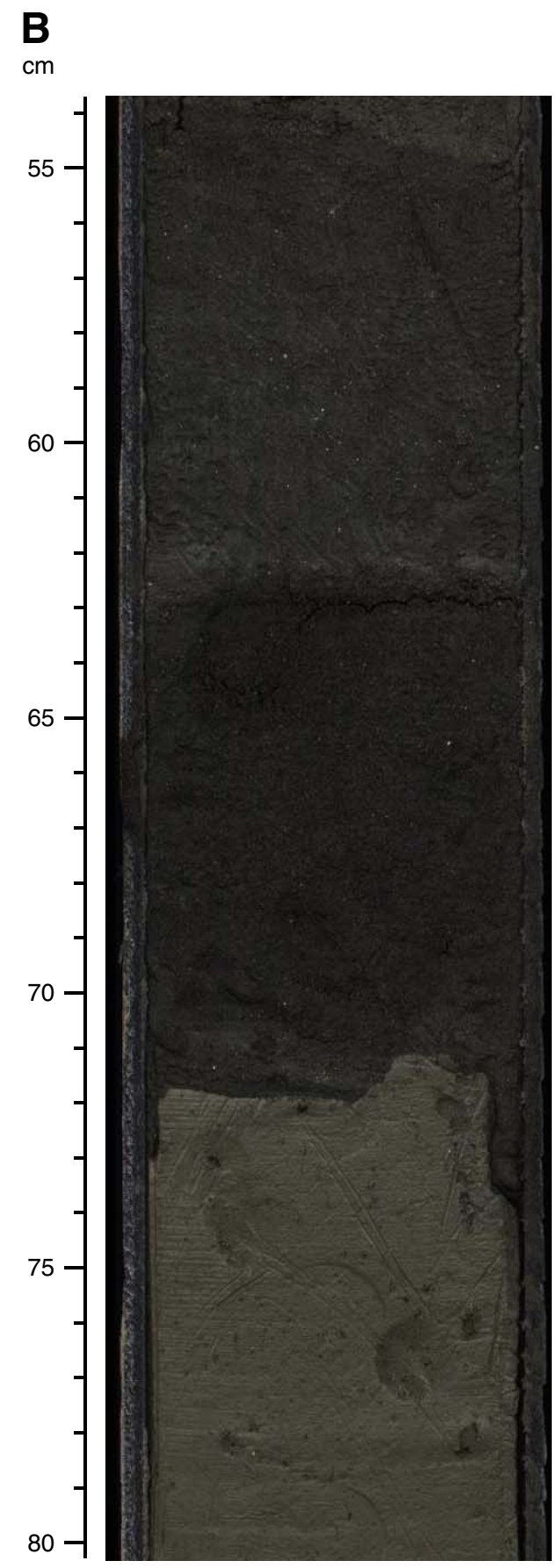


Figure F4. Core photograph showing intense green coloration, attributed to glauconite, on exterior of some woody pumice clasts (interval 331-C0017C-1H-2, 35-44 cm). Many other intervals had white pumice clasts with a more pervasive but less intense green coloration.

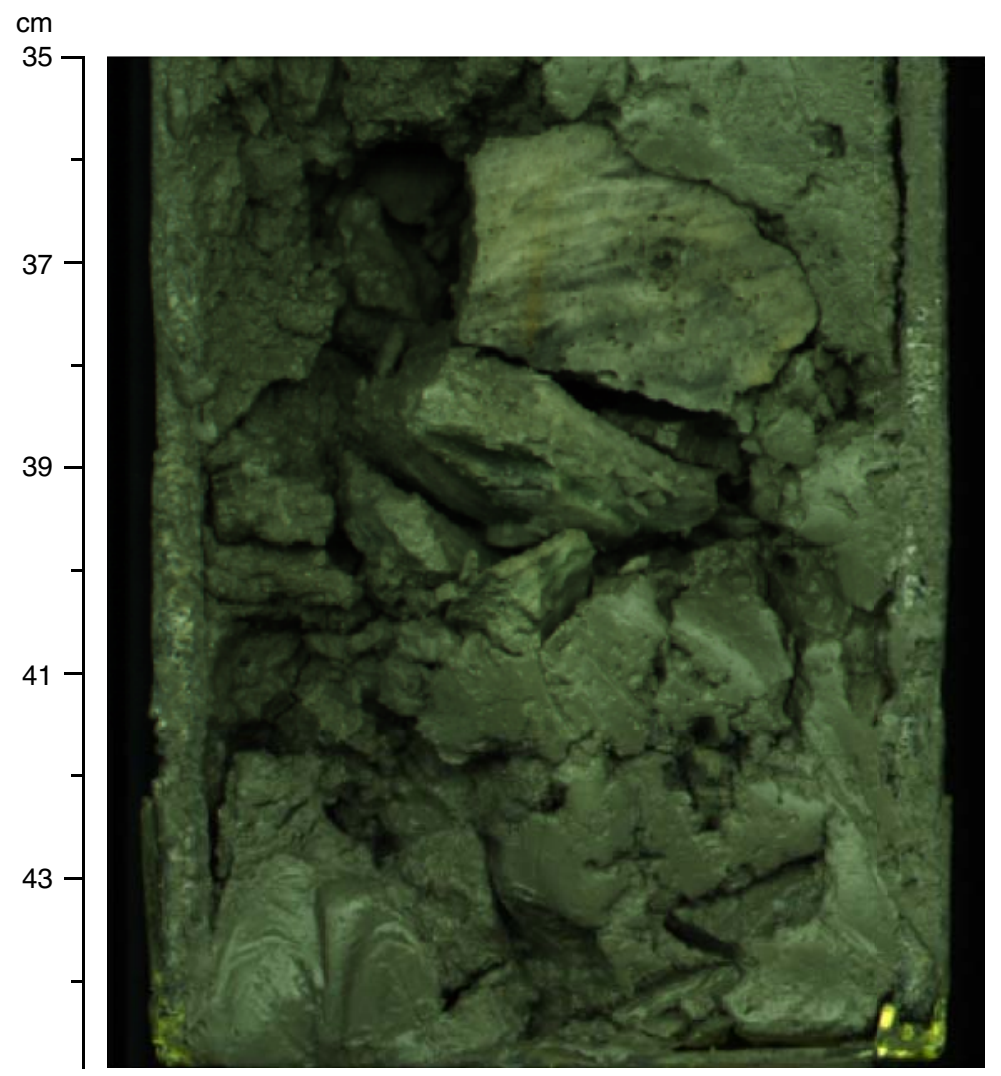


Figure F5. Series of focal scanning electron photomicrographs of a fecal pellet that has transported well-preserved coccoliths into the sediment at $10.6 \mathrm{mbsf}$, Site C0017. Note the preservation of the central area in the Emiliania huxleyi coccoliths (left side of F) and the bridge on the Gephyrocapsa oceanica (seen on the lower right side of $\mathrm{E}$ and $\mathrm{F}$ ).

A

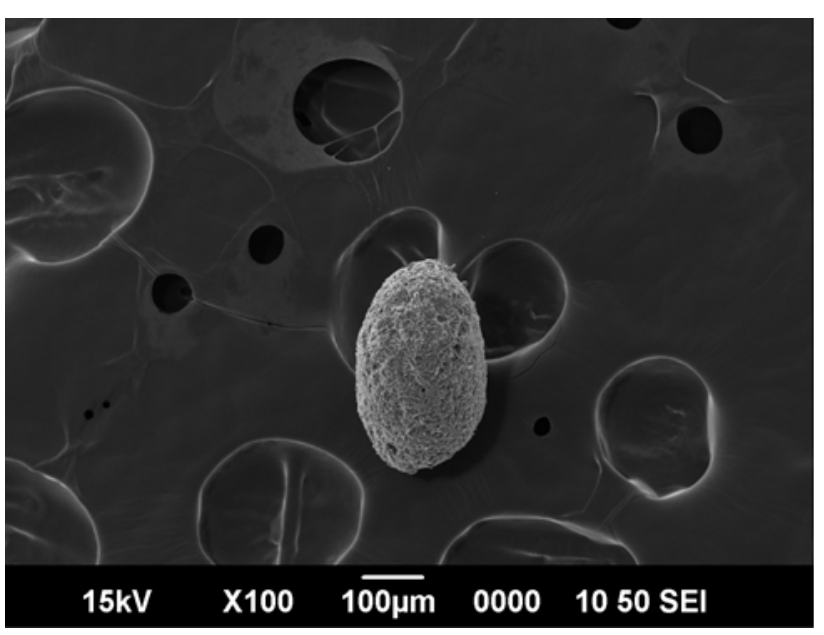

C

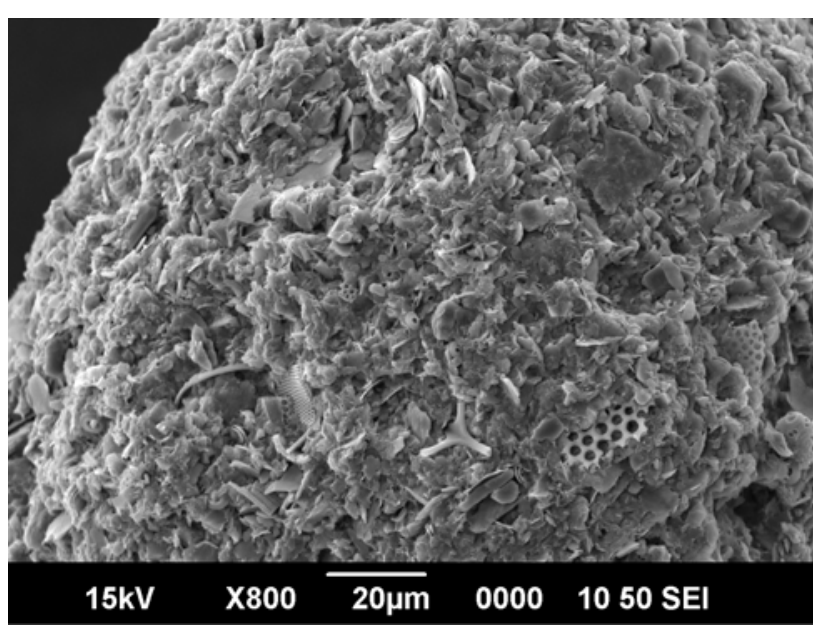

$\mathrm{E}$

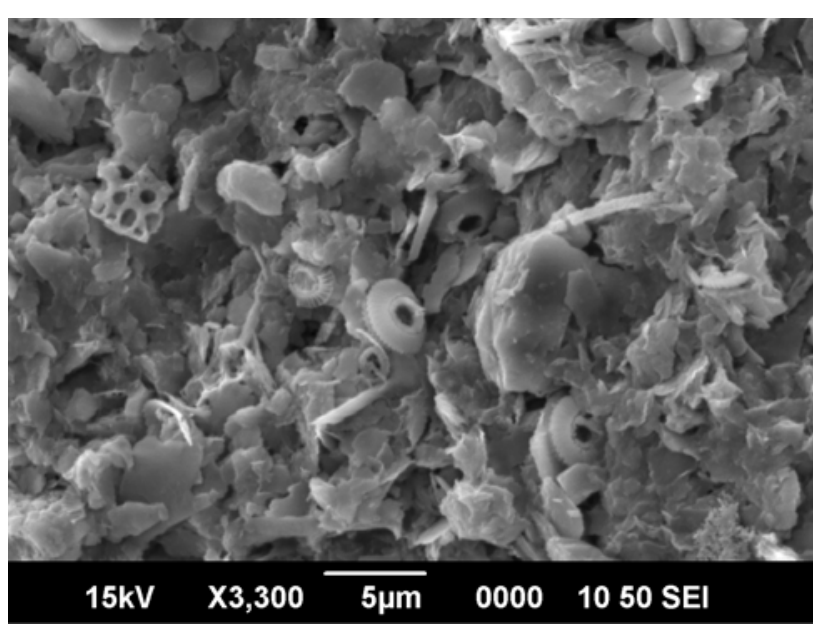

B

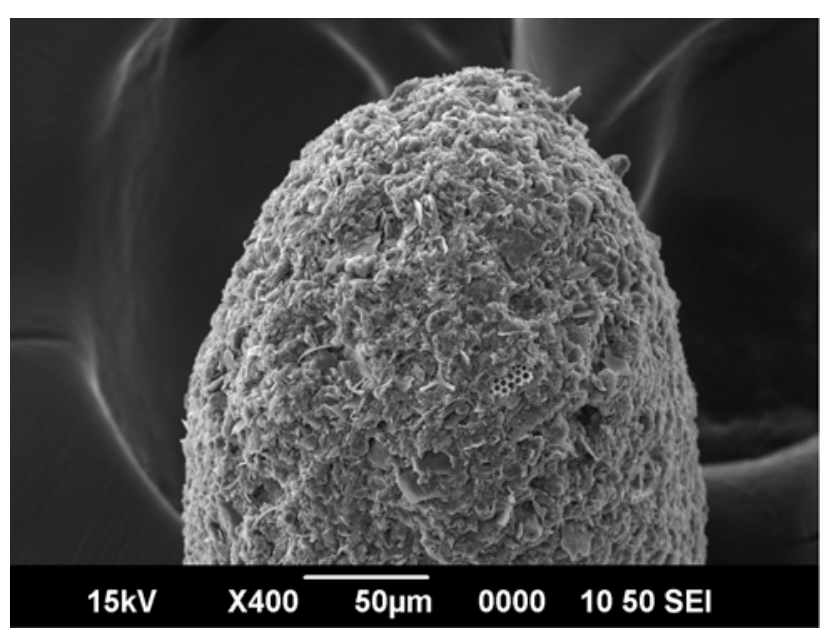

D

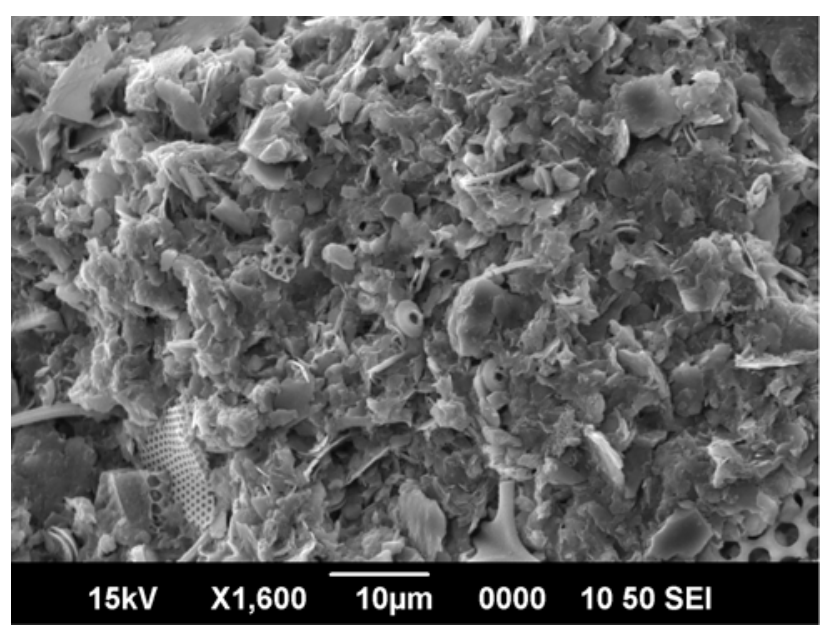

$\mathbf{F}$

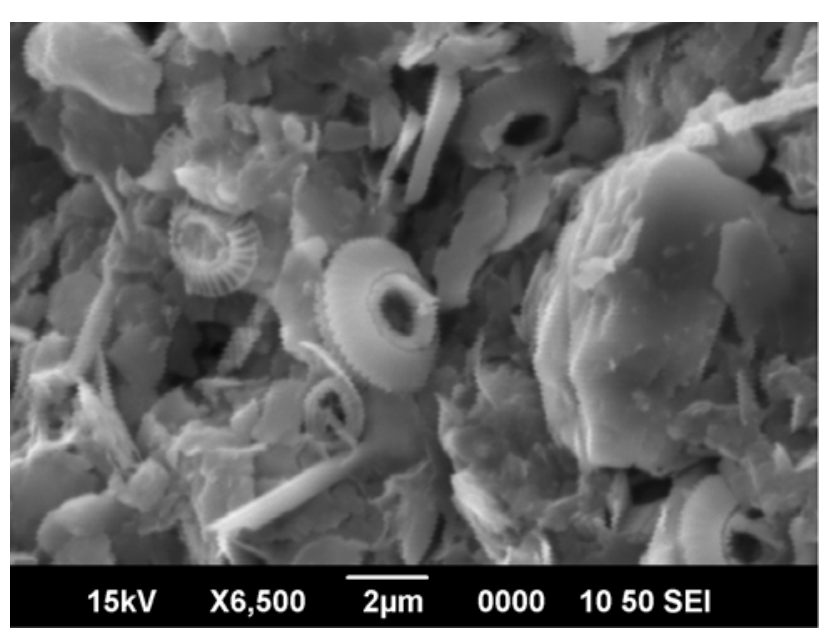


Figure F6. Core photograph showing oxidized pumiceous gravel (interval 331-C0017C-1H-7, 40-80 cm).

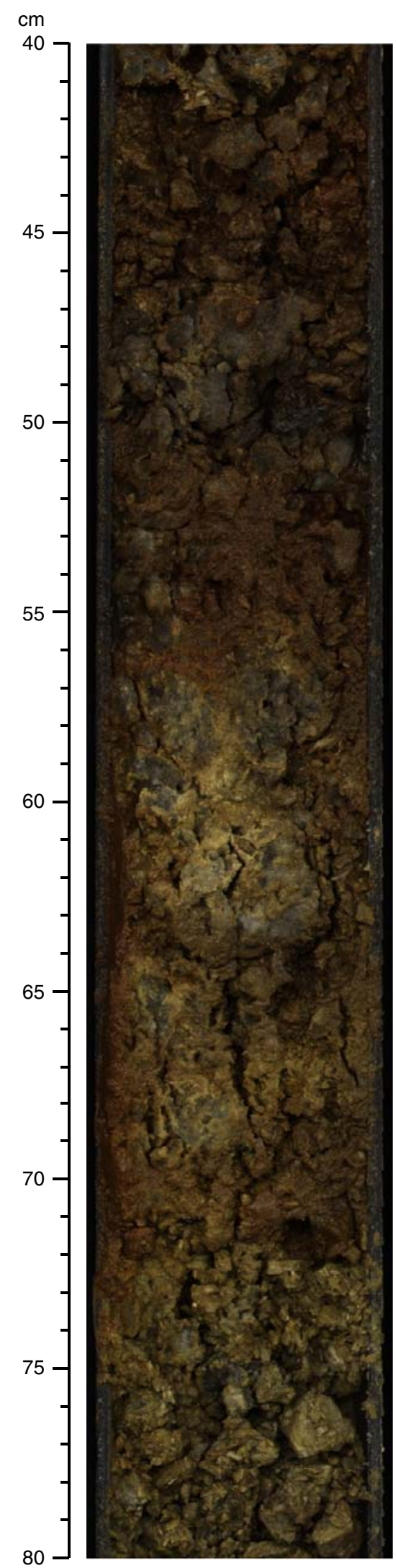


Figure F7. Core photograph showing pale, hydrothermally altered pumiceous grit intercalated with unaltered dark gray indurated clay (331-C0017D-11X-3, 40-80 cm).

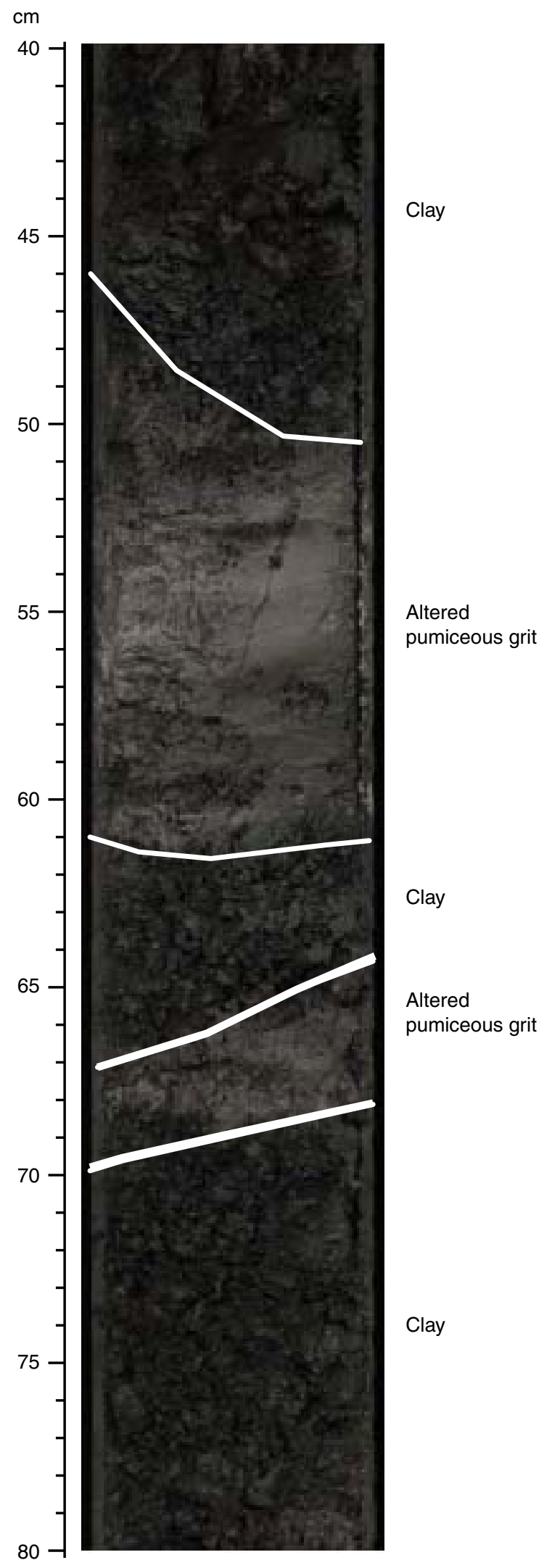




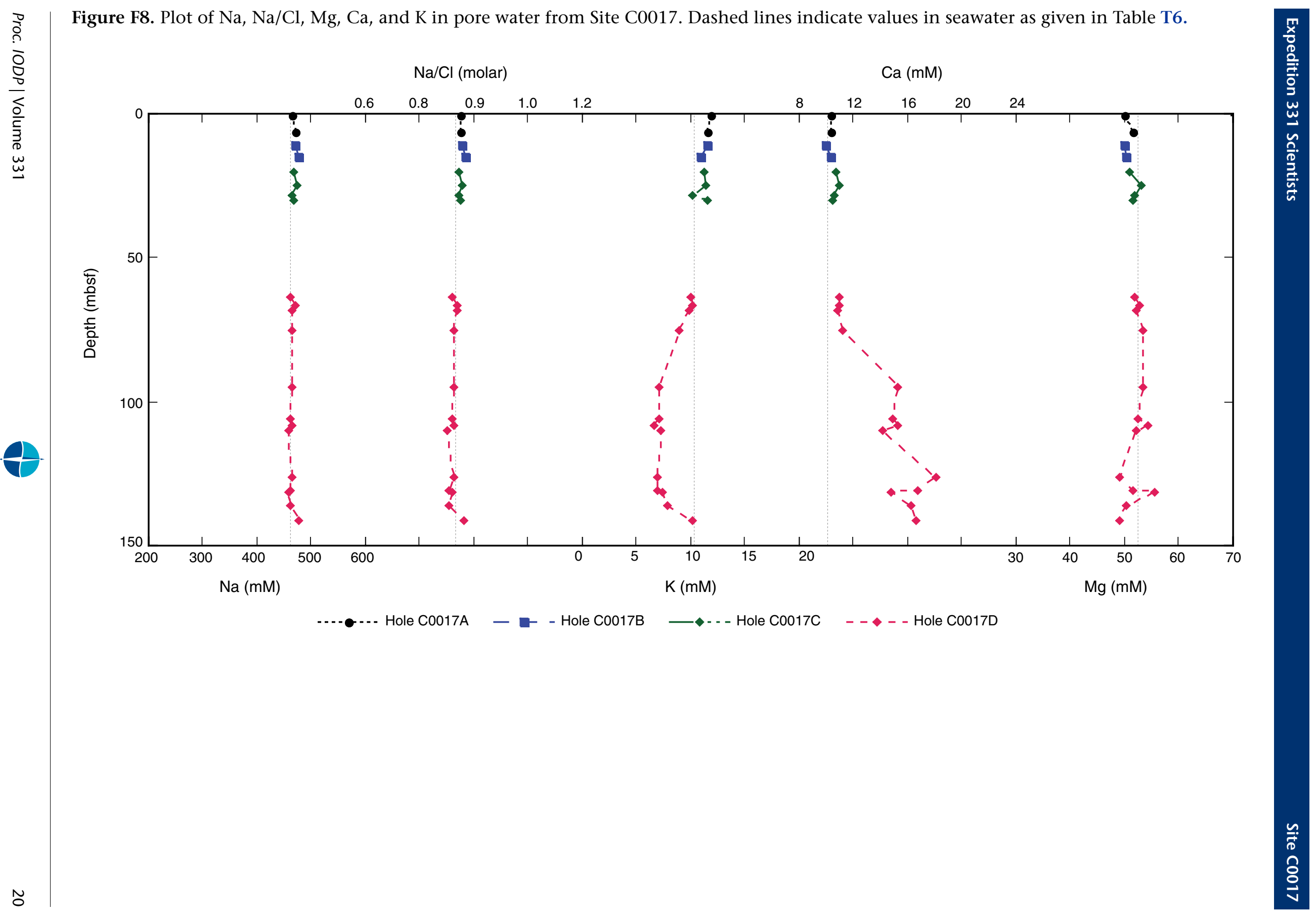


Figure F9. Plot of alkalinity, phosphate, ammonium, silicon (measured colorimetrically), and manganese in pore water from Site C0017. Note that values for ammonium that are labeled BD in Table T6 are plotted here as $0 \mu \mathrm{M}$.

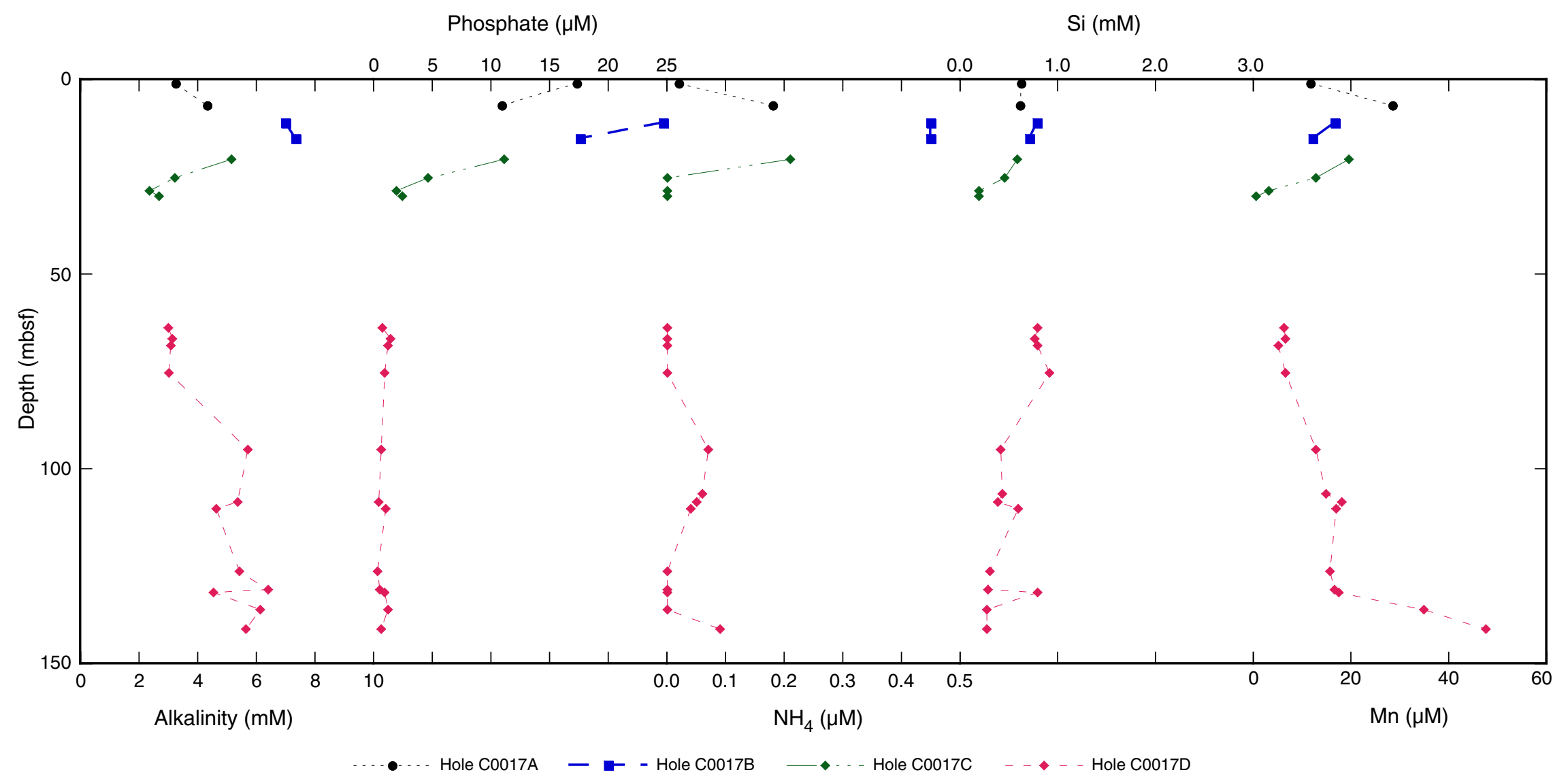




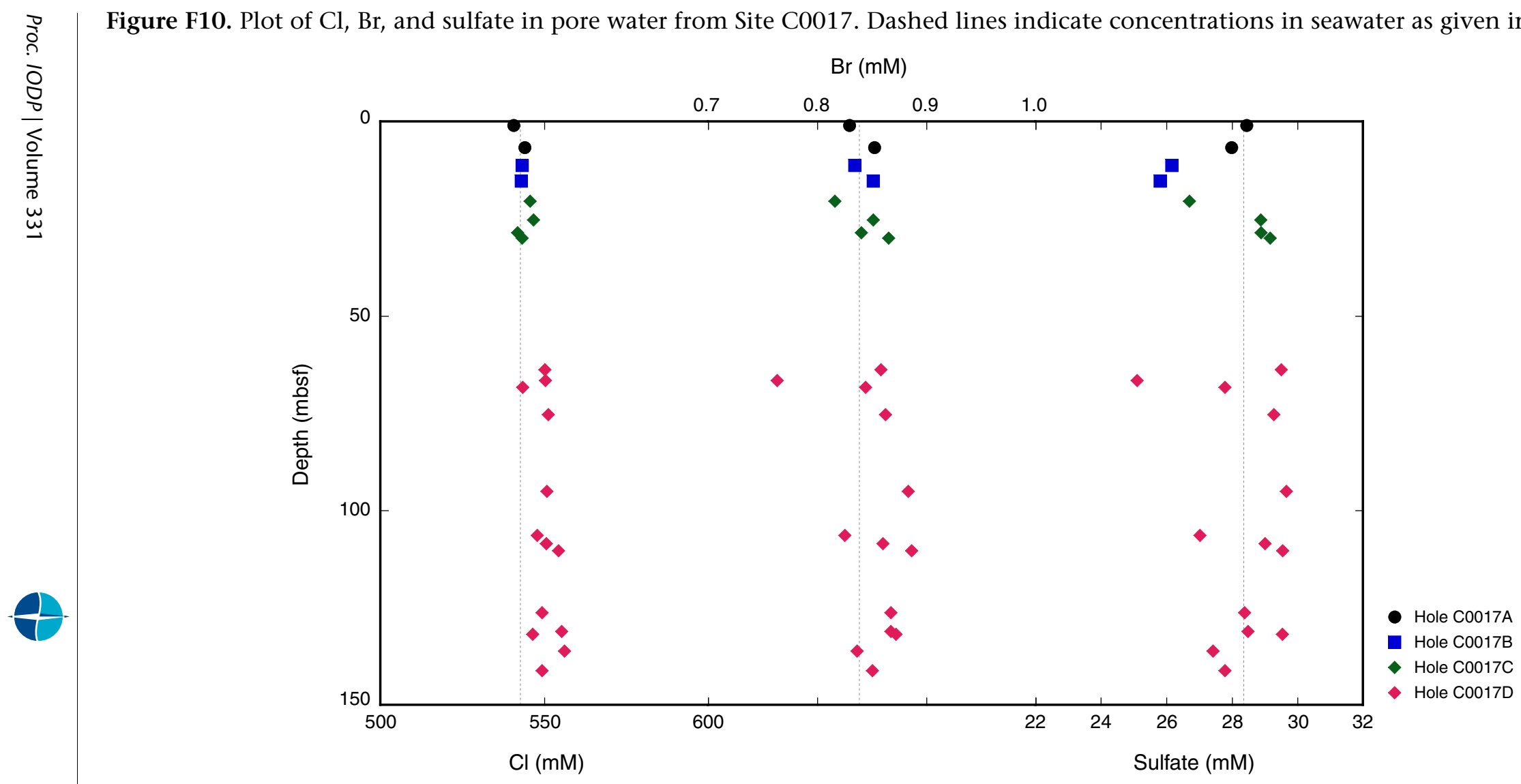




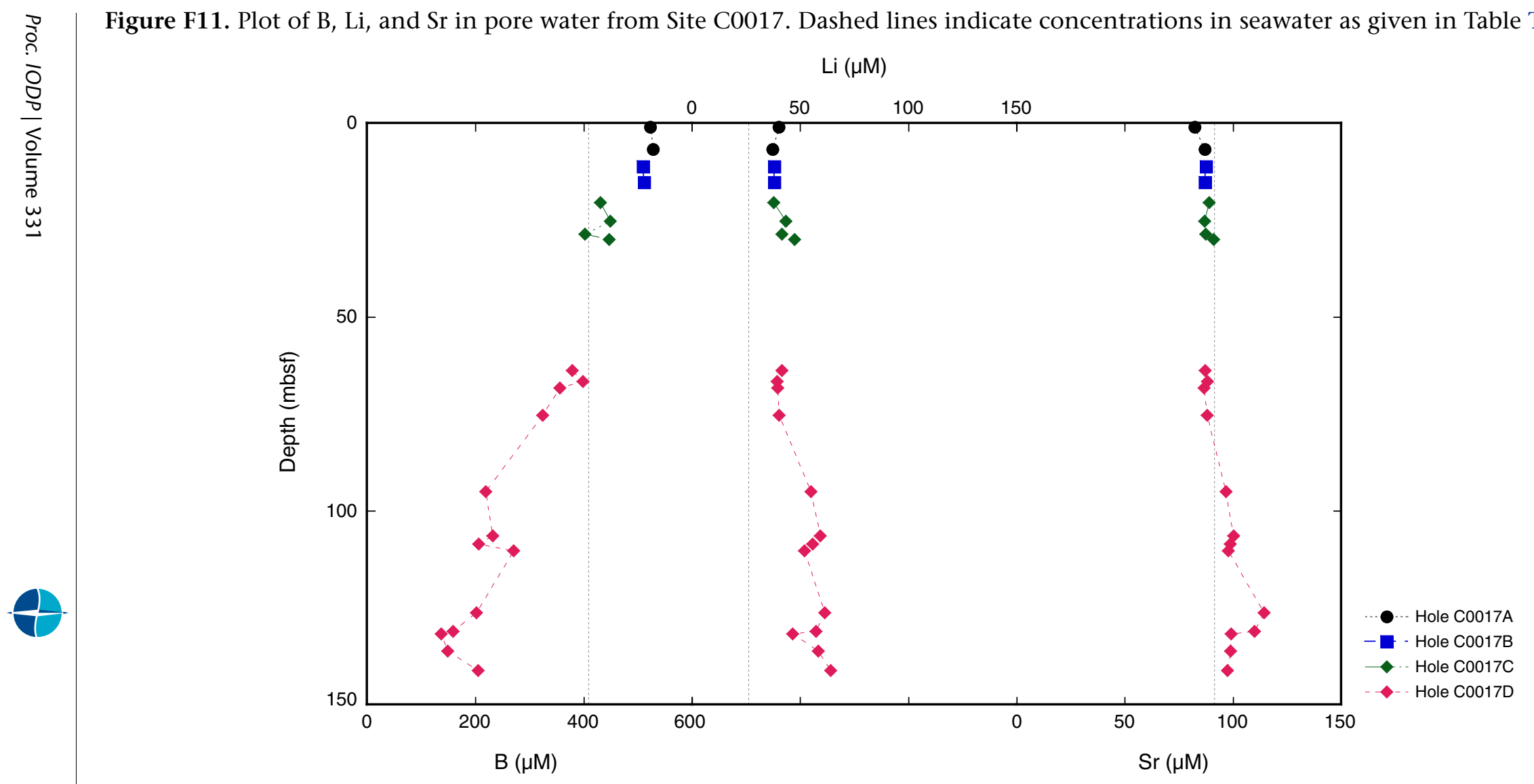


Figure F12. Plot of methane in headspace gas samples from Site C0017.

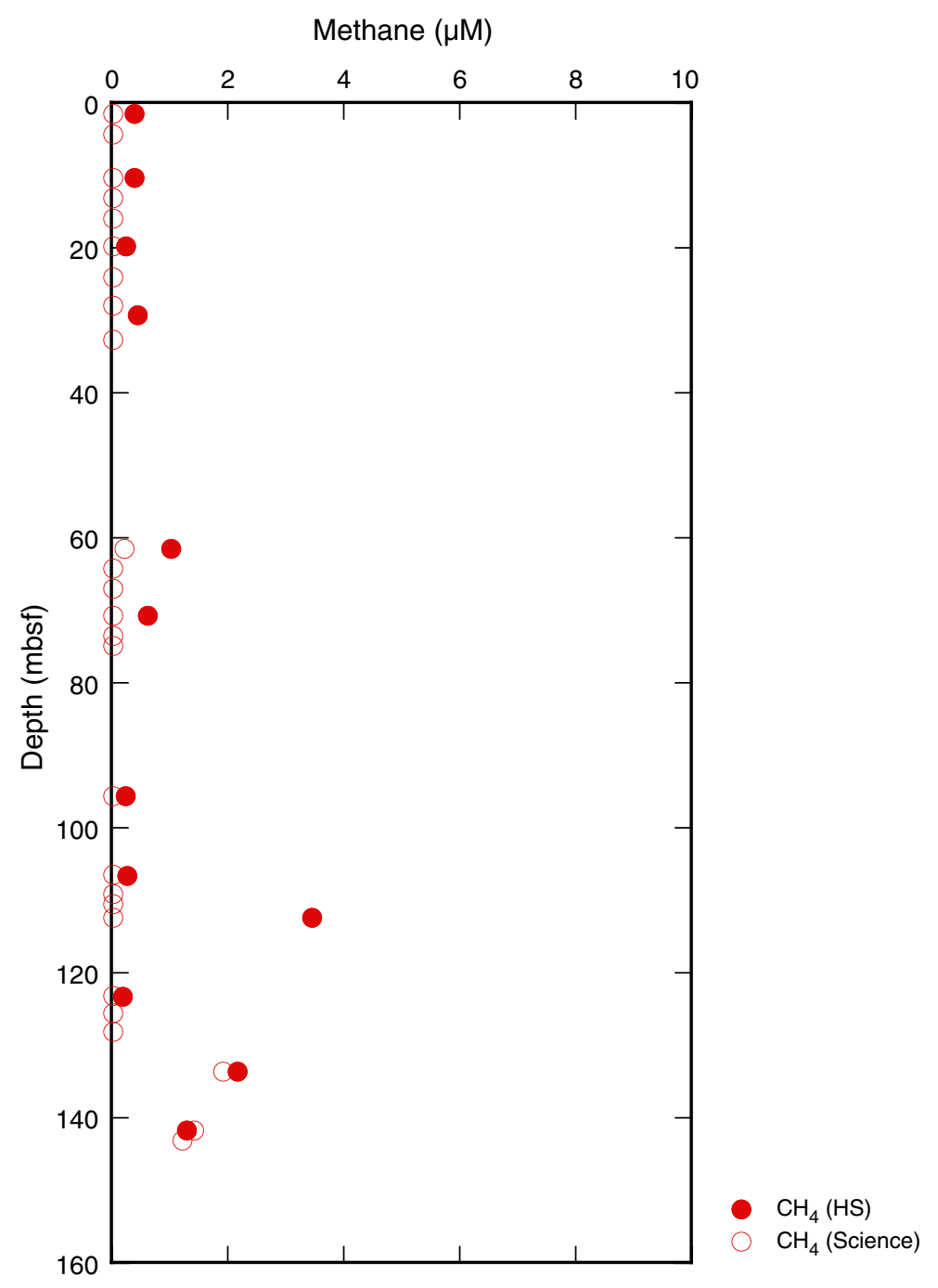


Figure F13. Plot of $\mathrm{CaCO}_{3}$ in sediment from Site C0017.

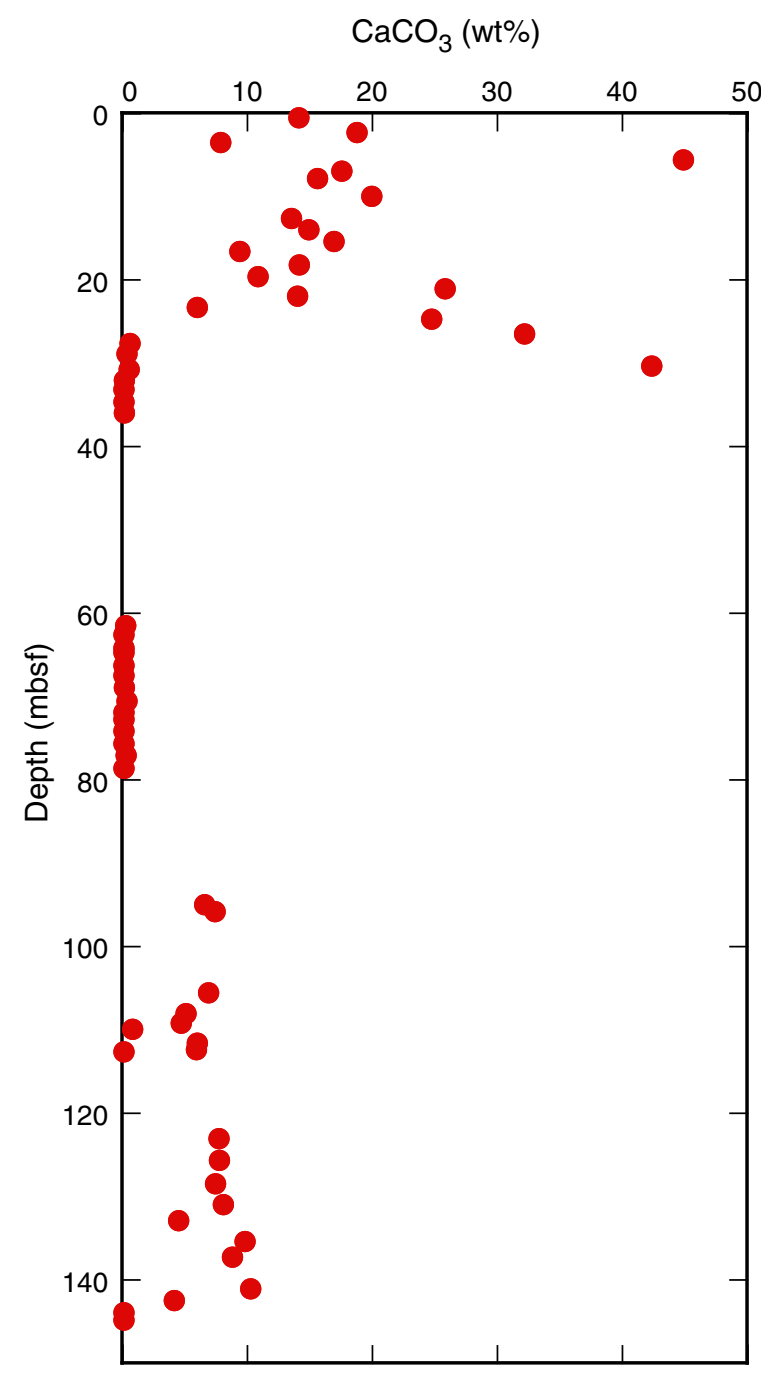




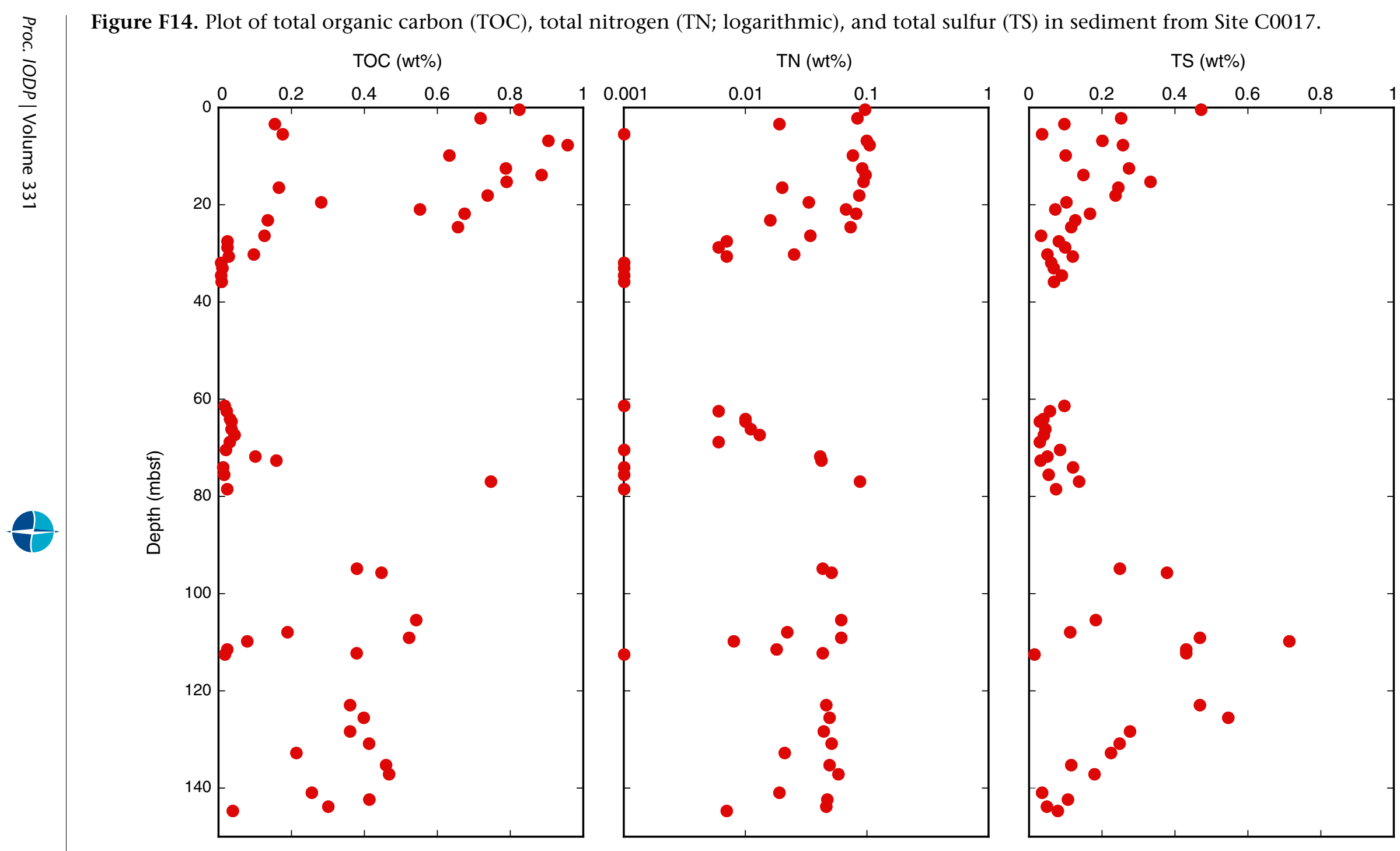


Figure F15. Plot of microbial cell counts at Site C0017. Open symbols indicate that cell counts are below our limit of detection (Expedition 331 Scientists, 2011b).

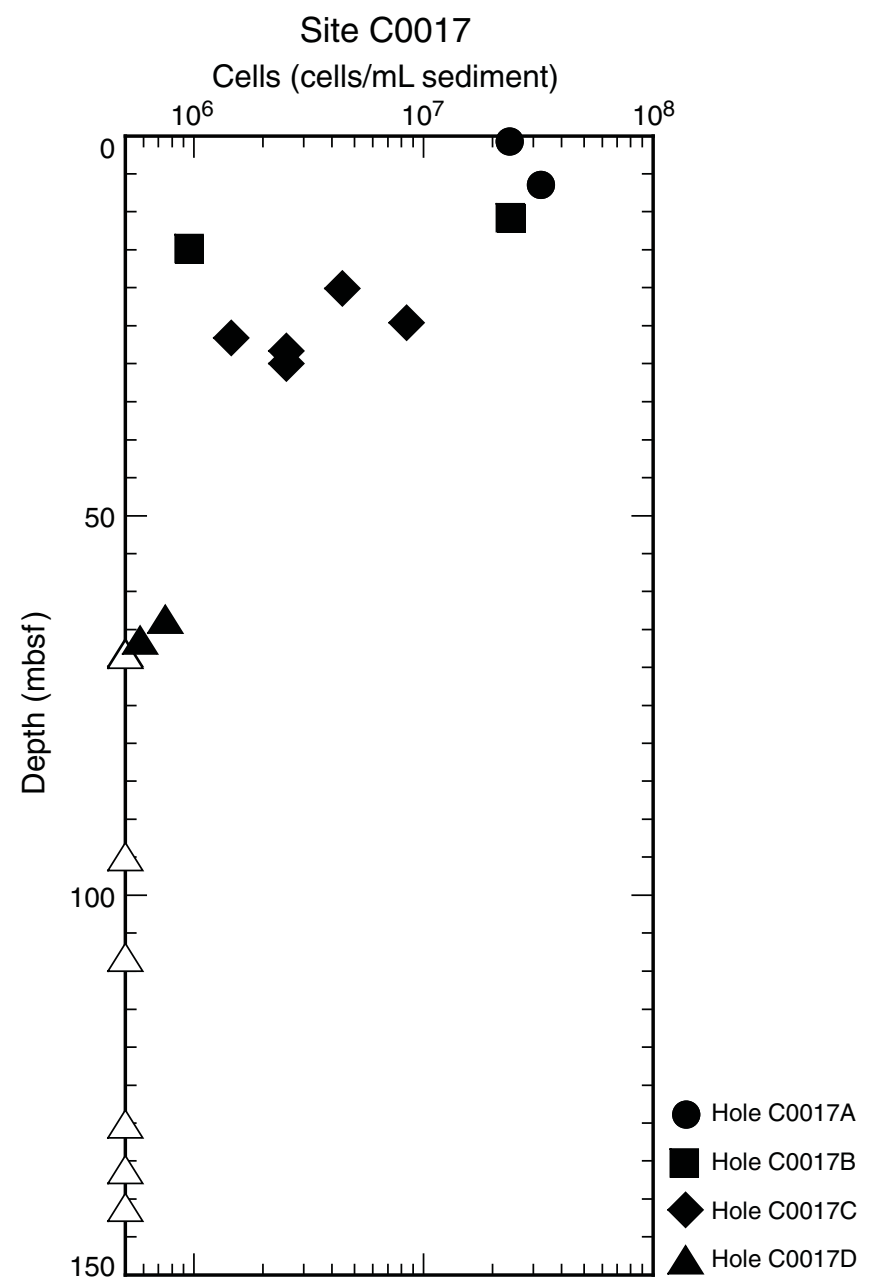


Figure F16. Paired photomicrograph images using epifluorescent (A, C, D, E, G) and phase contrast (B, D, F, H) microscopy. Arrows indicate the location of putative FeOB. A-D. Sample 331-C0017C-1H-6, ASW media A. E, F. Sample 331-C0017C-1H-7 \#2, ASW media A. G, H. Sample 331-C0017C-2H-1, ASW media A.

A

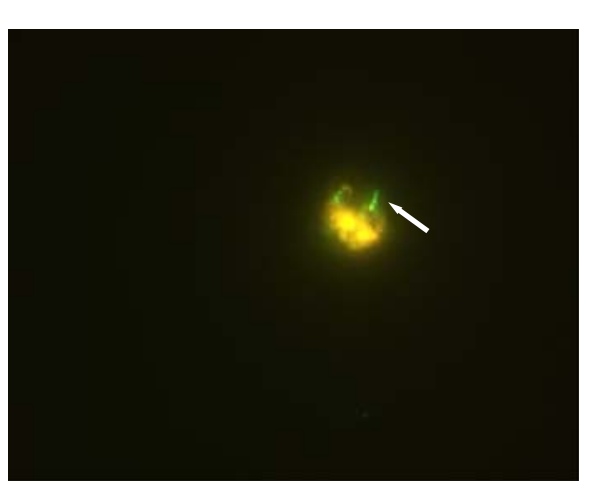

C

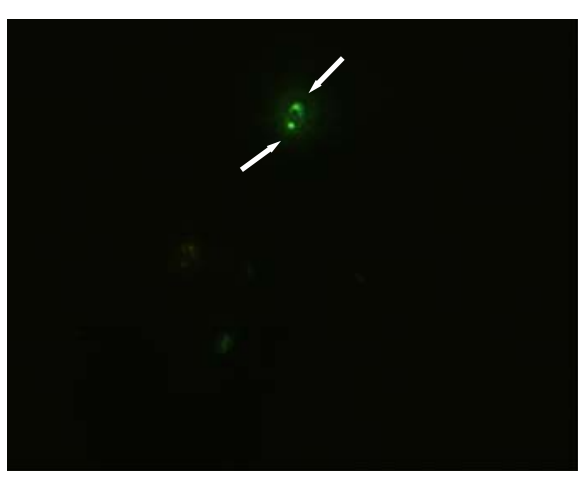

E

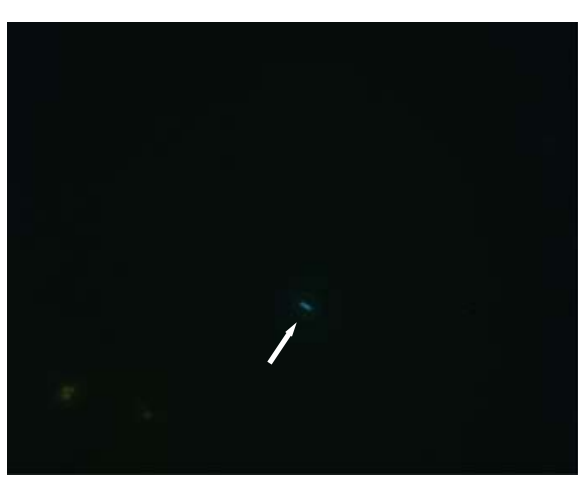

G

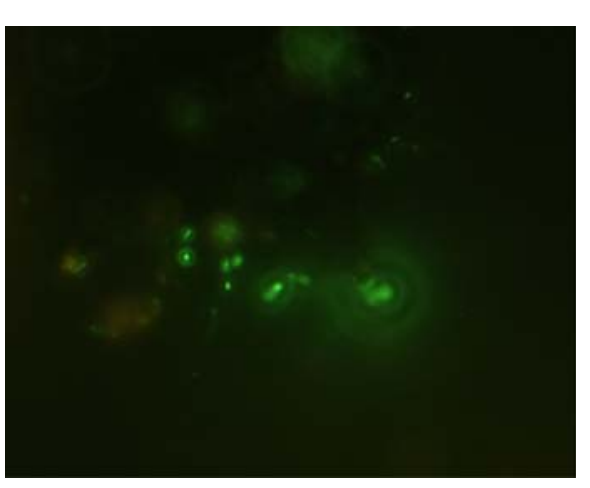

B

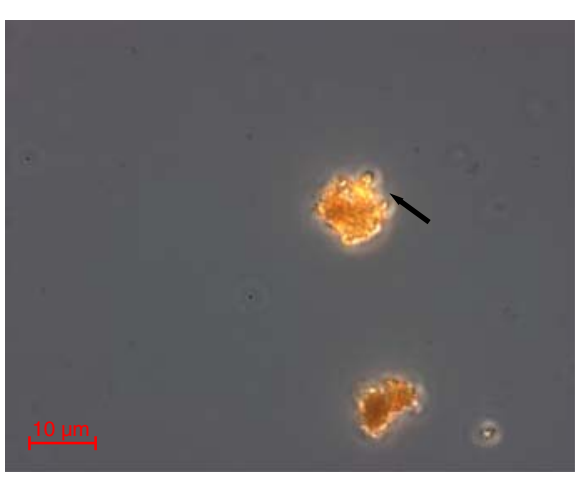

D

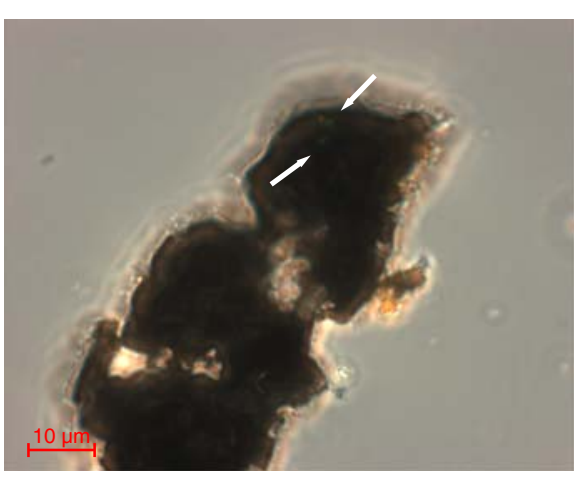

$\mathbf{F}$

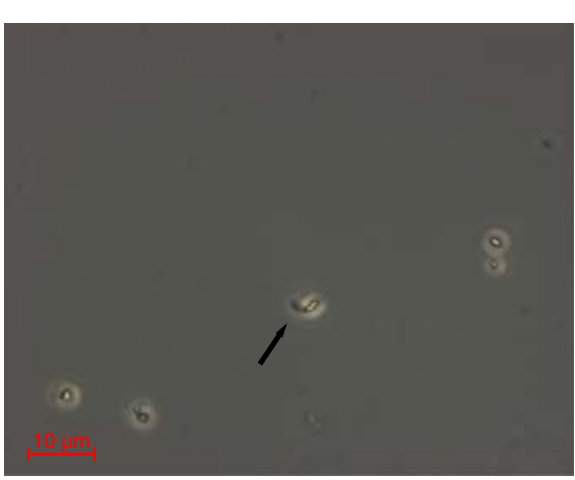

H

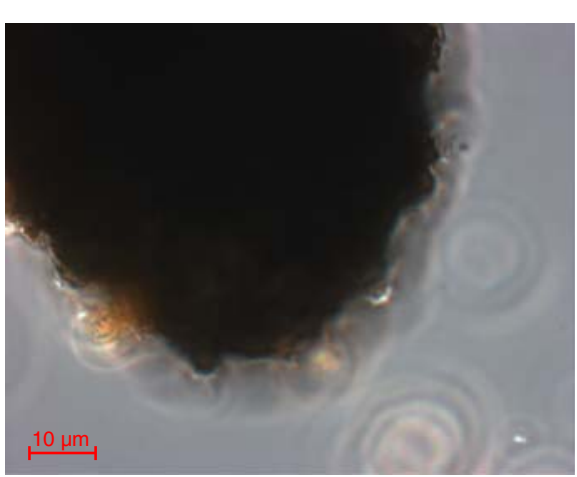


Figure F17. SEM photomicrographs with corresponding EDS spectra and quantitative analysis showing (A) filamentous iron and $(\mathbf{B}, \mathbf{C})$ iron oxides, possibly of biotic origin. All photomicrographs are from the original Section 331-C0017C-1H-7 before the enrichment experiments for that sample were carried out. The red circle indicates the location where the EDS spectrum was taken. cps = counts per second.

A

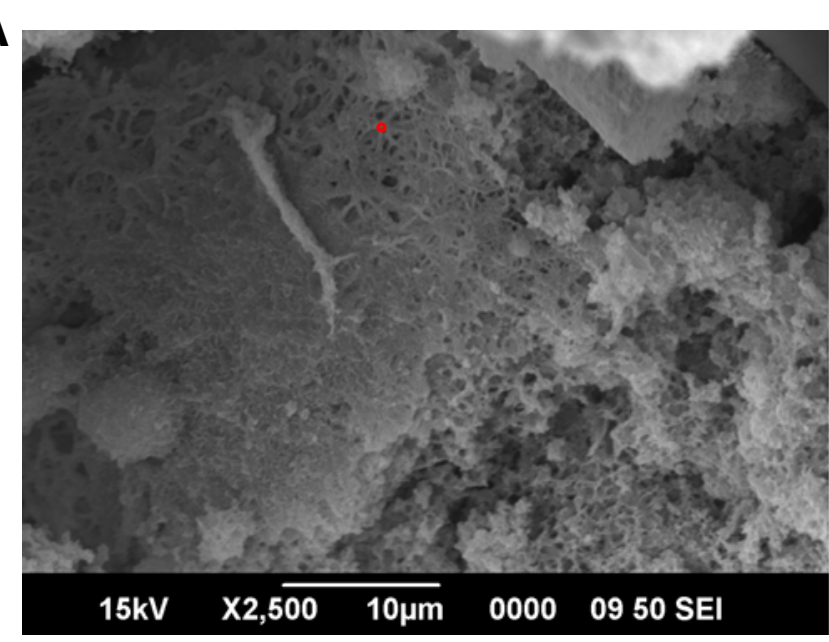

B

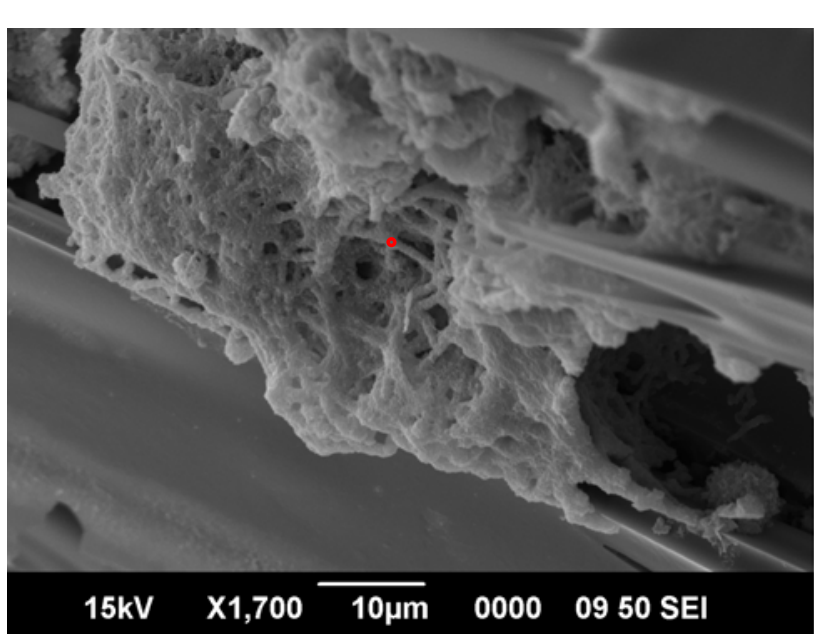

C

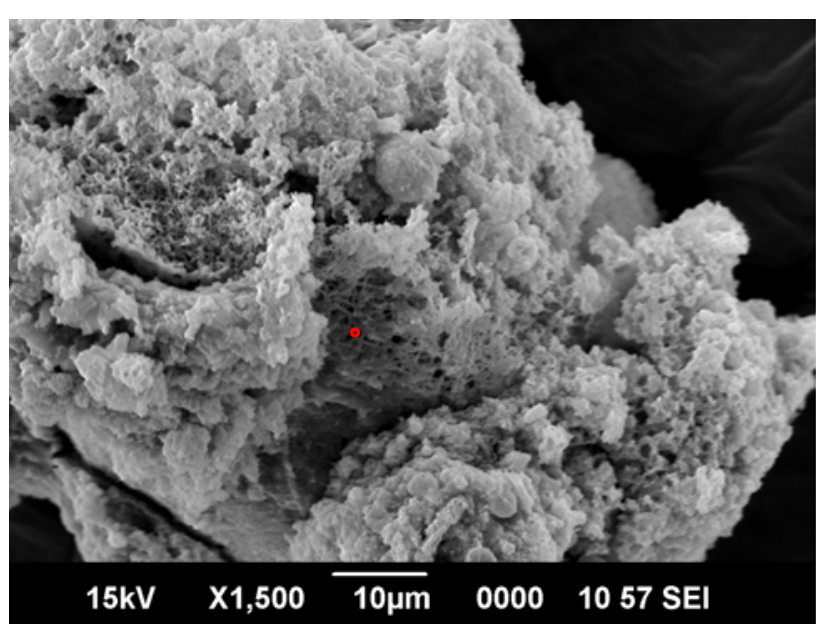

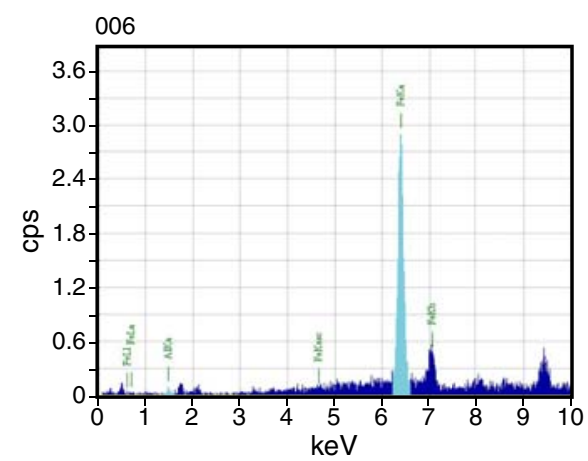

Element keV Mass\% Error\% Atom\%

$\begin{array}{lllll}\text { Al } & 1.486 & 0.06 & 0.01 & 0.99\end{array}$

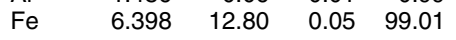

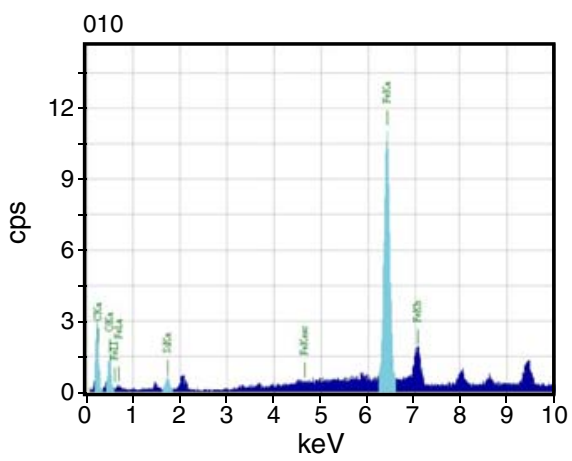

Element keV Mass\% Error\% Atom\%

$\begin{array}{lllll}\text { C } & 0.277 & 2.59 & 0.04 & 42.77\end{array}$

$\begin{array}{lllll}\mathrm{O} & 0.525 & 0.28 & 0.06 & 3.45\end{array}$

$\begin{array}{lllll}\text { Si } & 1.739 & 0.11 & 0.01 & 0.77\end{array}$

$\begin{array}{lllll}\mathrm{Fe} & 6.398 & 14.93 & 0.04 & 53.00\end{array}$

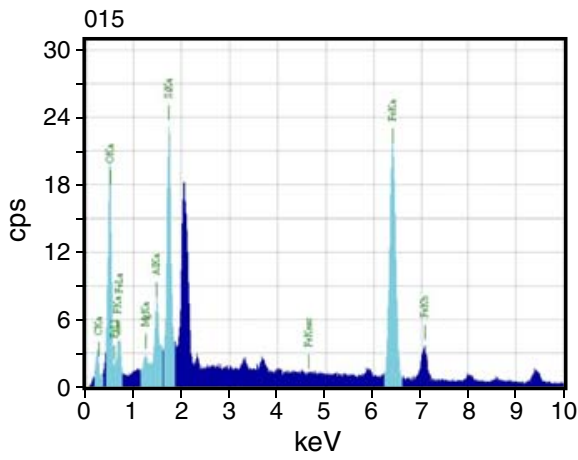

Element keV Mass\% Error\% Atom\%

$\begin{array}{lllll}\mathrm{C} & 0.277 & 2.38 & 0.36 & 15.96 \\ \mathrm{O} & 0.525 & 3.99 & 0.39 & 20.04\end{array}$

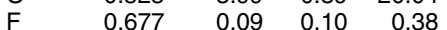

$\begin{array}{lllll}M g & 1.253 & 0.31 & 0.09 & 1.04\end{array}$

$\begin{array}{llllr}\text { Al } & 1.486 & 1.26 & 0.08 & 3.77 \\ \text { Si } & 1.739 & 4.55 & 0.08 & 13.02\end{array}$

$\begin{array}{lllll}\mathrm{Fe} & 6.398 & 31.82 & 0.32 & 45.81\end{array}$ 
Figure F18. Plot of discrete measurements of bulk density (solid symbols) and GRA-derived bulk density (open symbols) from the multisensor logger for whole-round samples (MSCL-W), Site C0017. GRA-derived bulk density values $<0 \mathrm{~g} / \mathrm{cm}^{3}$ are omitted for clarity.

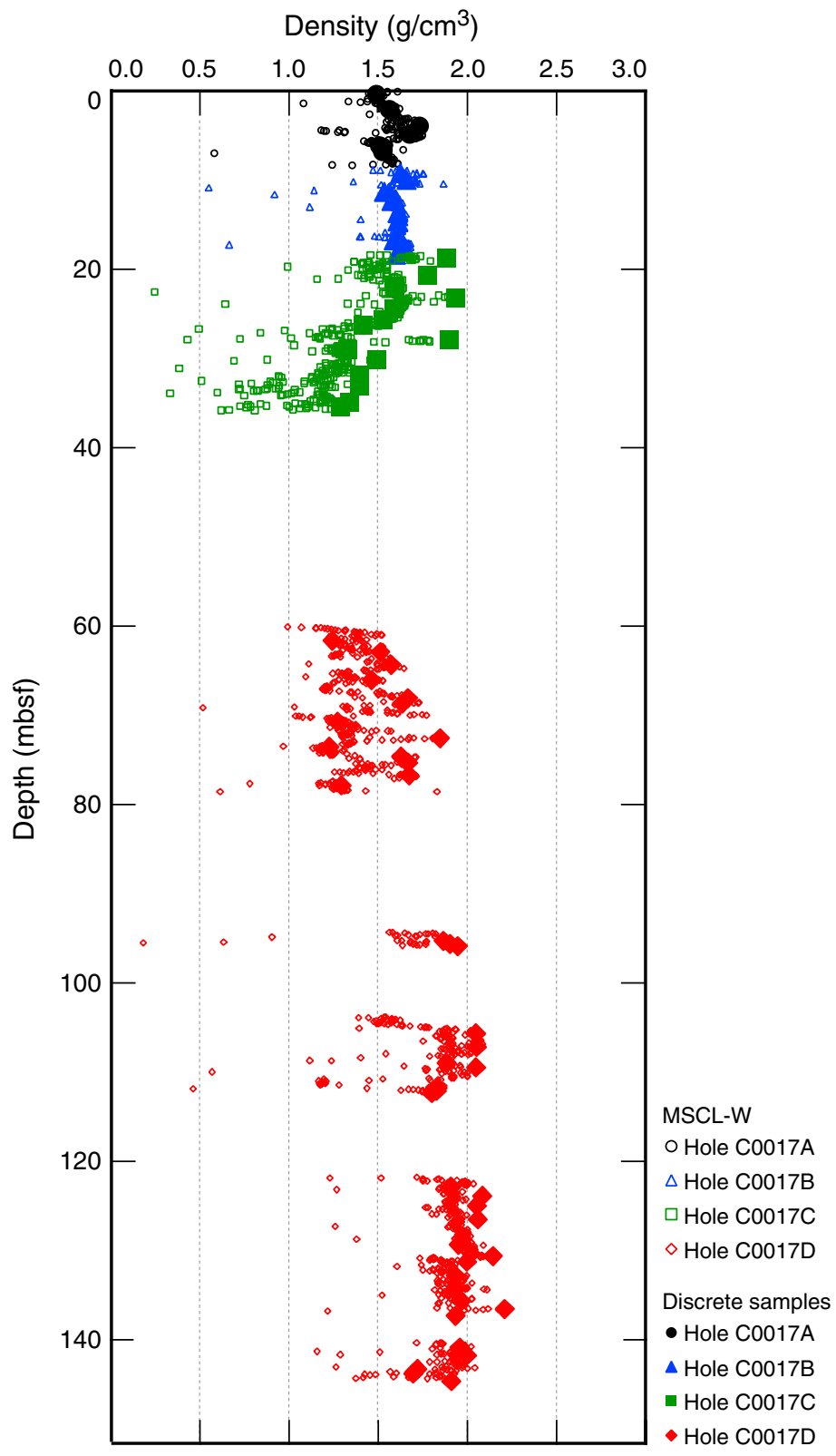


Figure F19. Plot of porosity calculated from discrete MAD measurements, Site C0017. GRA-derived bulk density values $<0 \mathrm{~g} / \mathrm{cm}^{3}$ are omitted for clarity.

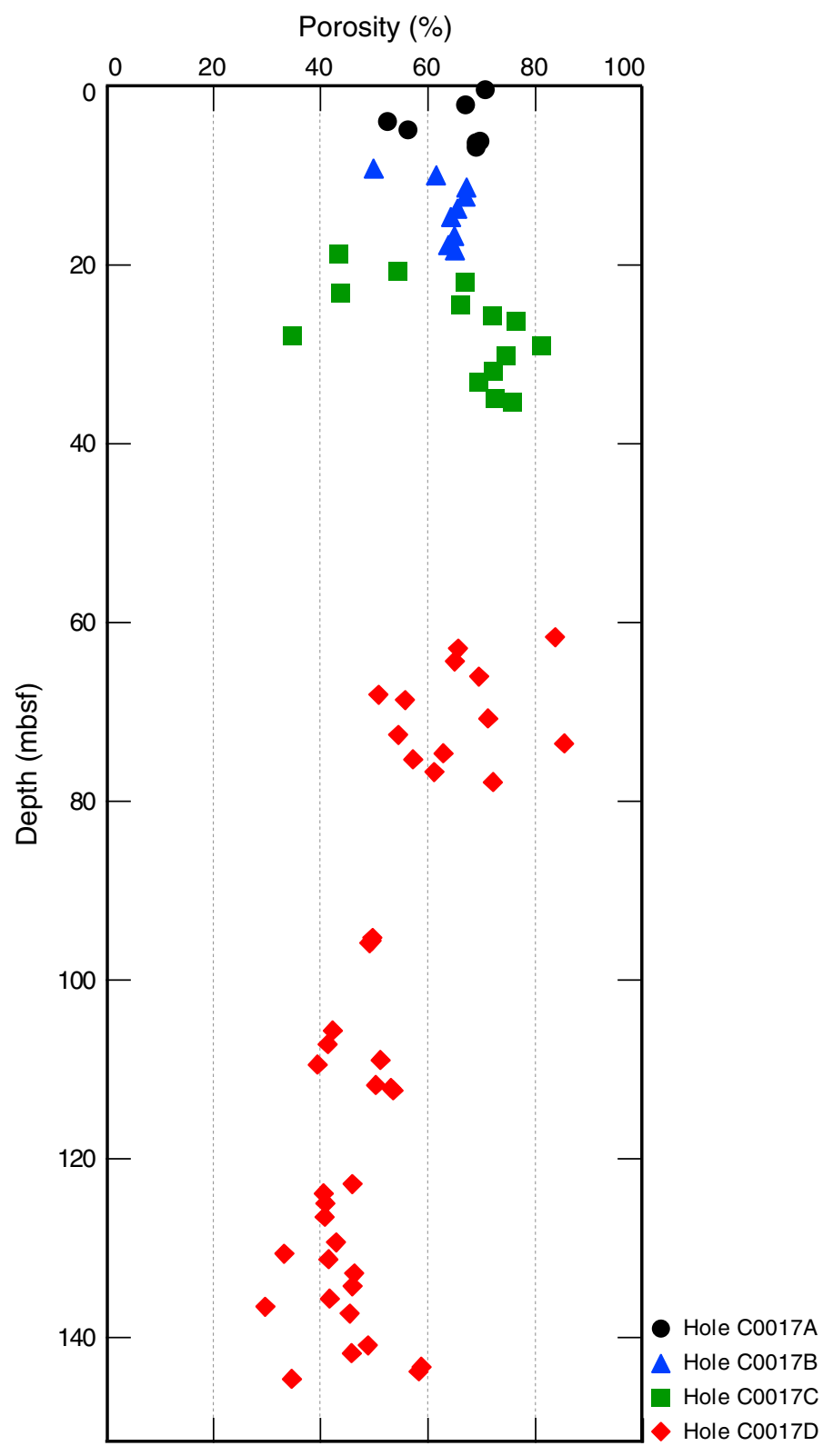


Figure F20. Plot of formation factor calculated from discrete electrical resistivity measurements, Site C0017.

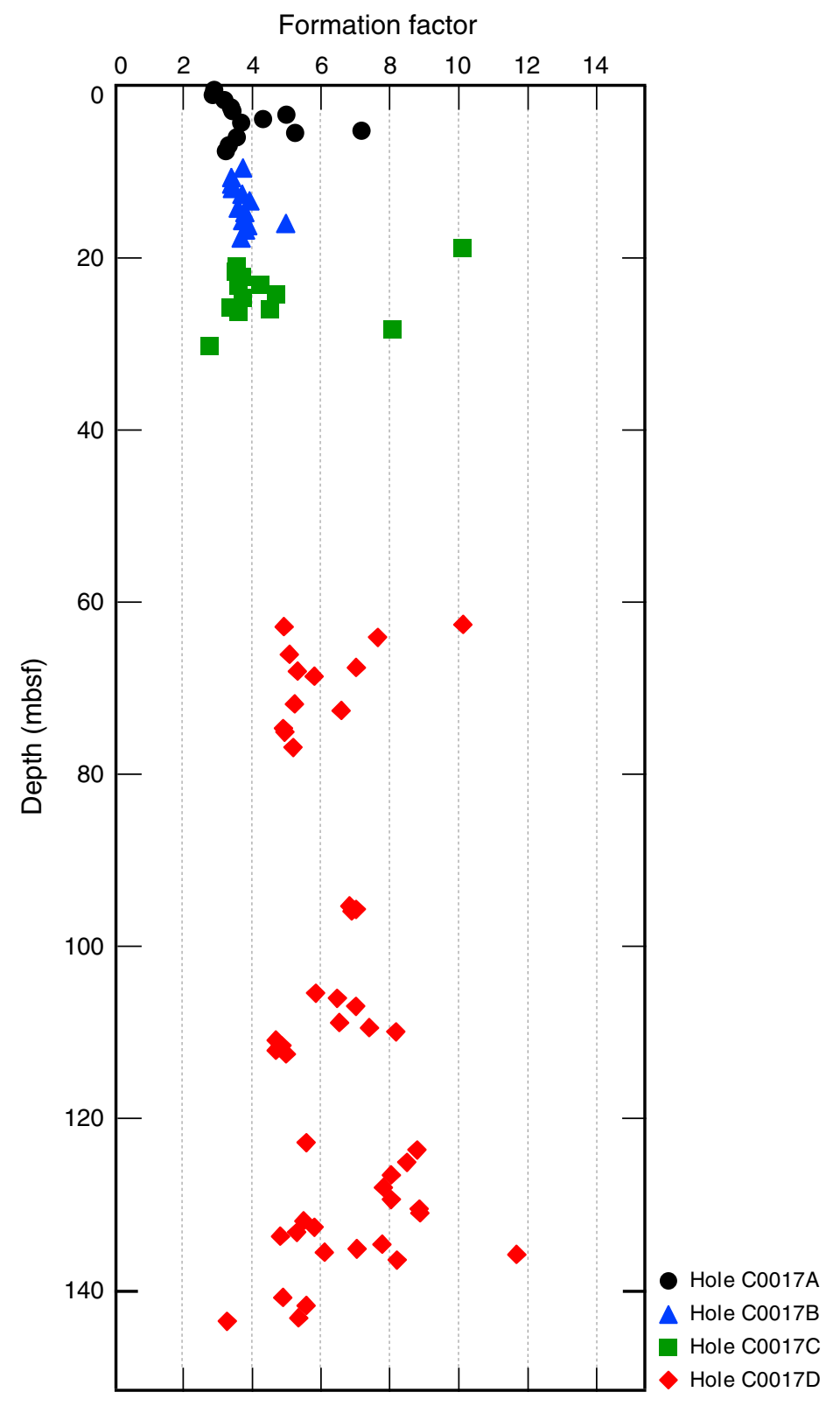


Figure F21. Plot of MSCL-derived $P$-wave velocity, Site C0017.

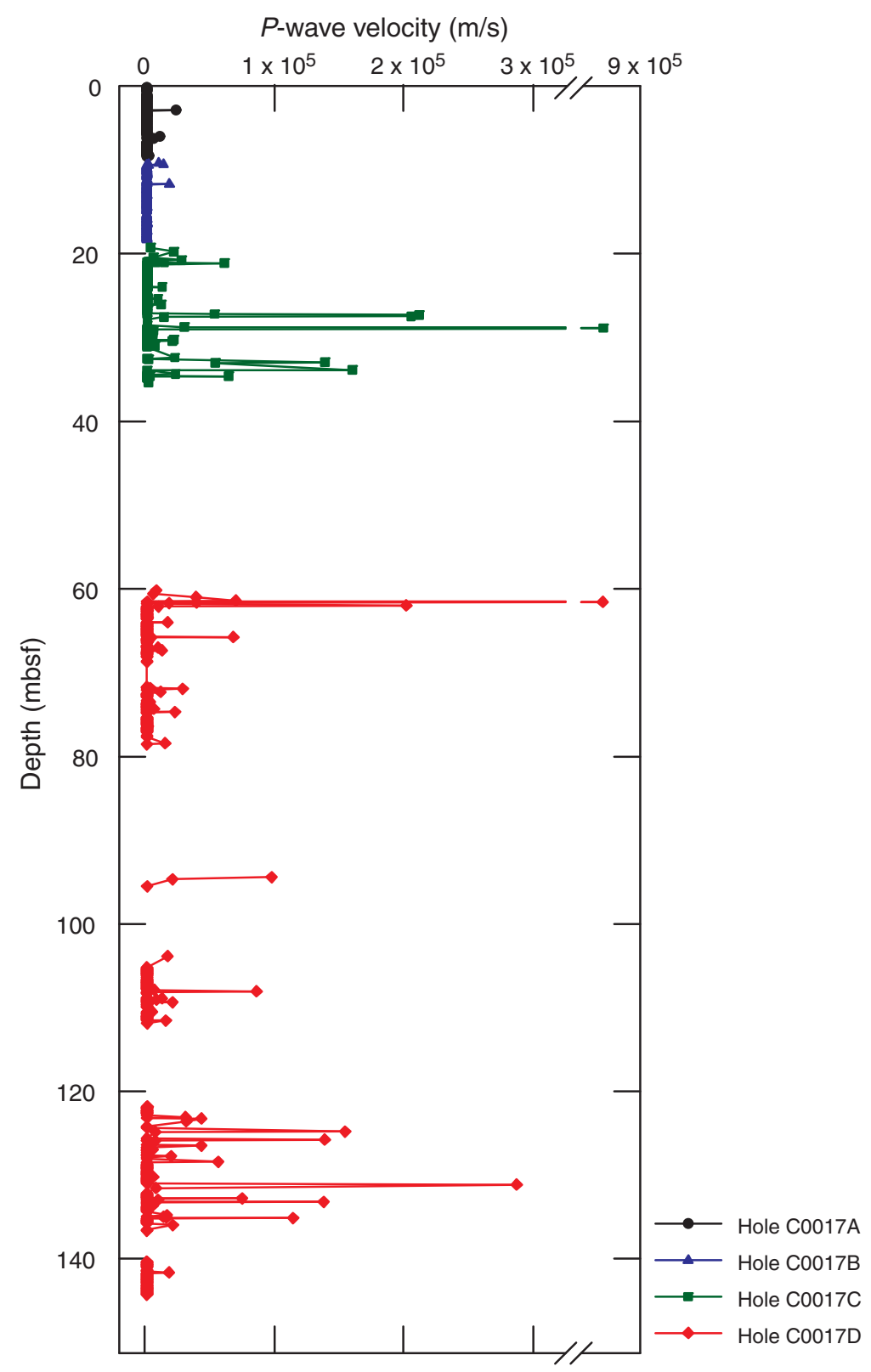


Figure F22. Plot of thermal conductivity, Site C0017.

Thermal conductivity $(\mathrm{W} /[\mathrm{m} \cdot \mathrm{K}])$

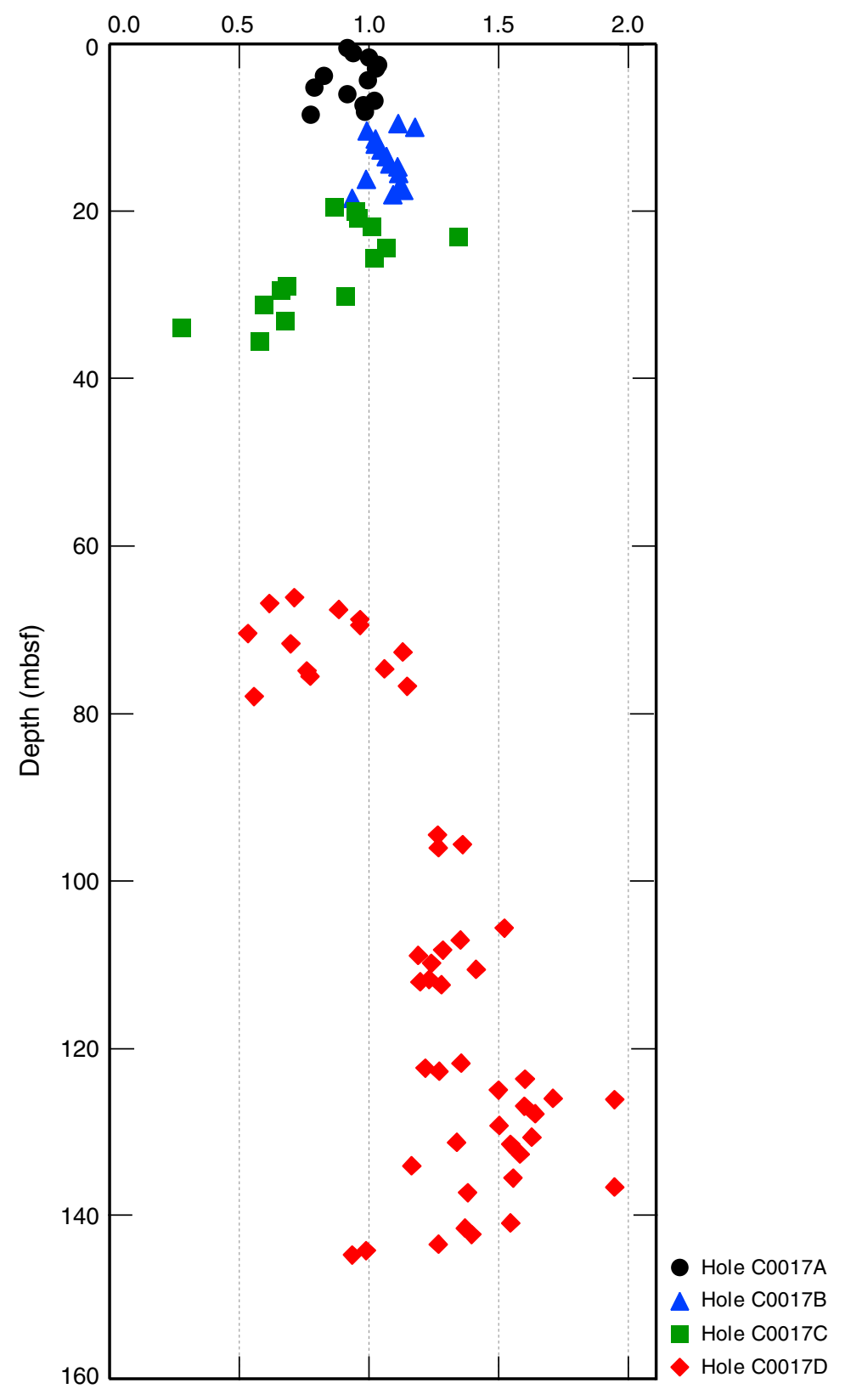


Figure F23. Plot of equilibrium temperature (red circles) and thermal conductivity, Site C0017. The point at 0 mbsf is the average bottom water temperature. Temperatures between 0 and 112 mbsf are from the APCT3 tool, and the temperature at $150.7 \mathrm{mbsf}$ is derived from the thermoseal on the core barrel.

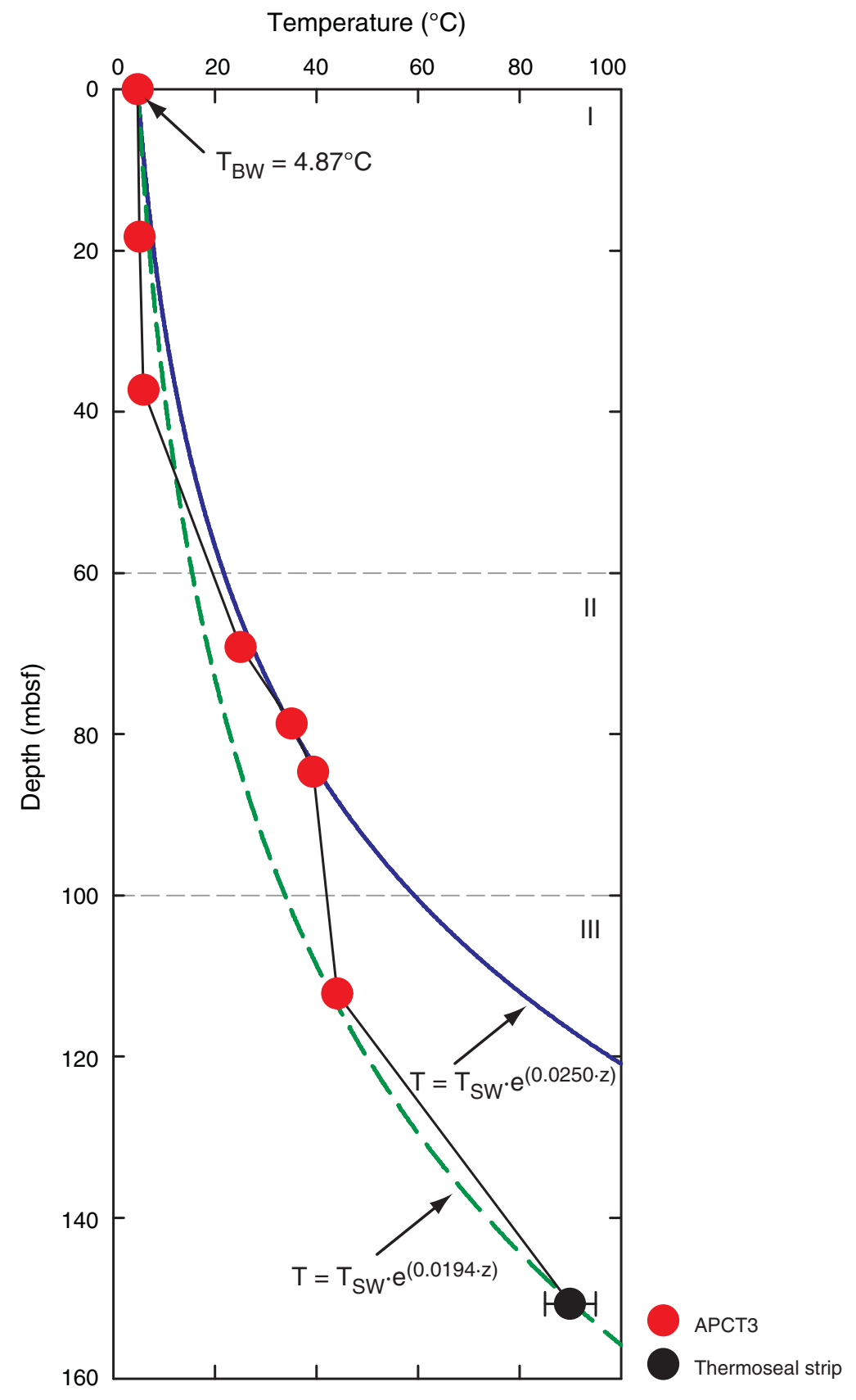


Figure F24. Temperature-time series measured during the deployment of the advanced piston corer temperature (APCT3) tool at Site C0017 (blue line). Unshaded area = data used for equilibrium temperature fit, red line $=$ theoretical equilibrium curve, triangle $=$ beginning of fit, inverted triangle $=$ end of fit, dashed red line with circles = estimate of equilibrium temperature. Note frictional heating at penetration (dashed vertical line). A. Core 331-C0017B-1H, 18.3 mbsf. B. Core 331-C0017C-2H, 37.3 mbsf. C. Core 331-C0017D-1H, 69.2 mbsf. D. Core 331-C0017D-2H, 78.7 mbsf. (Continued on next page.)

Time after penetration (s)
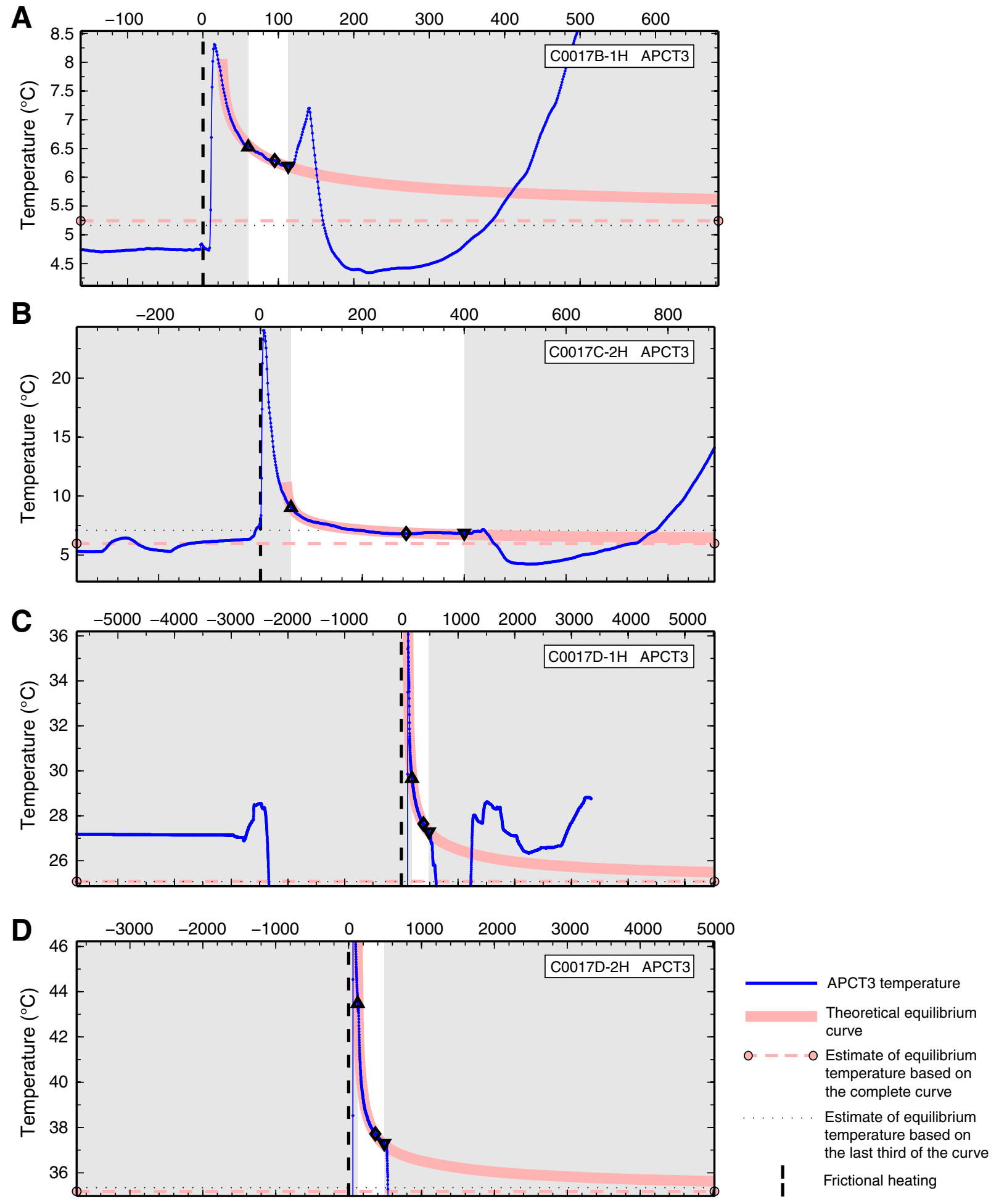
Figure F24 (continued). E. Core 331-C0017D-3H, 84.7 mbsf. F. Core 331-C0017D-4H, 84.7 mbsf. G. Core 331C0017D-7H, 112.2 mbsf. H. Core 331-C0017D-12H, 150.7 mbsf.

Time after penetration (s)
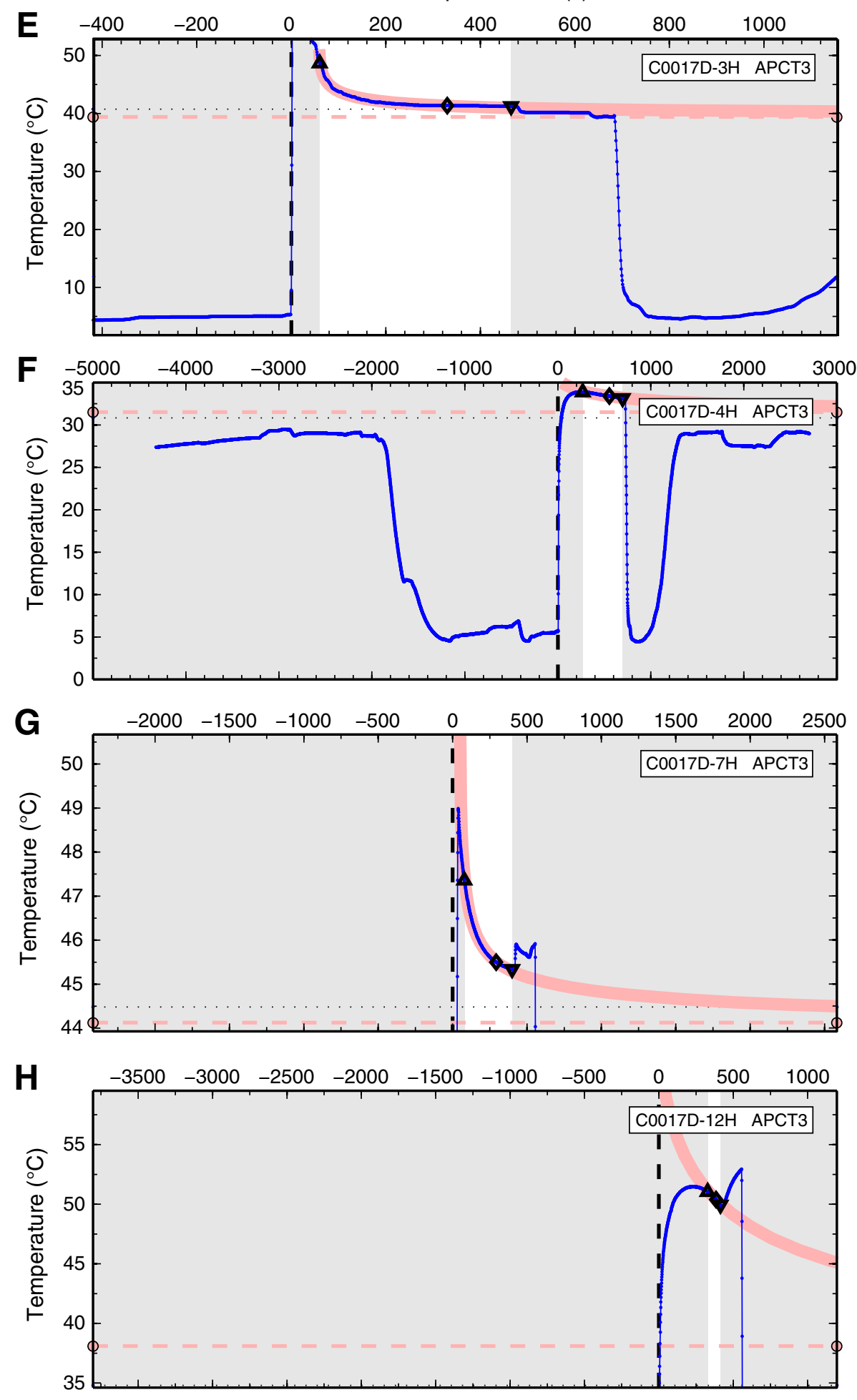
Figure F25. Plot of MSCL-W derived electrical resistivity, Site C0017.

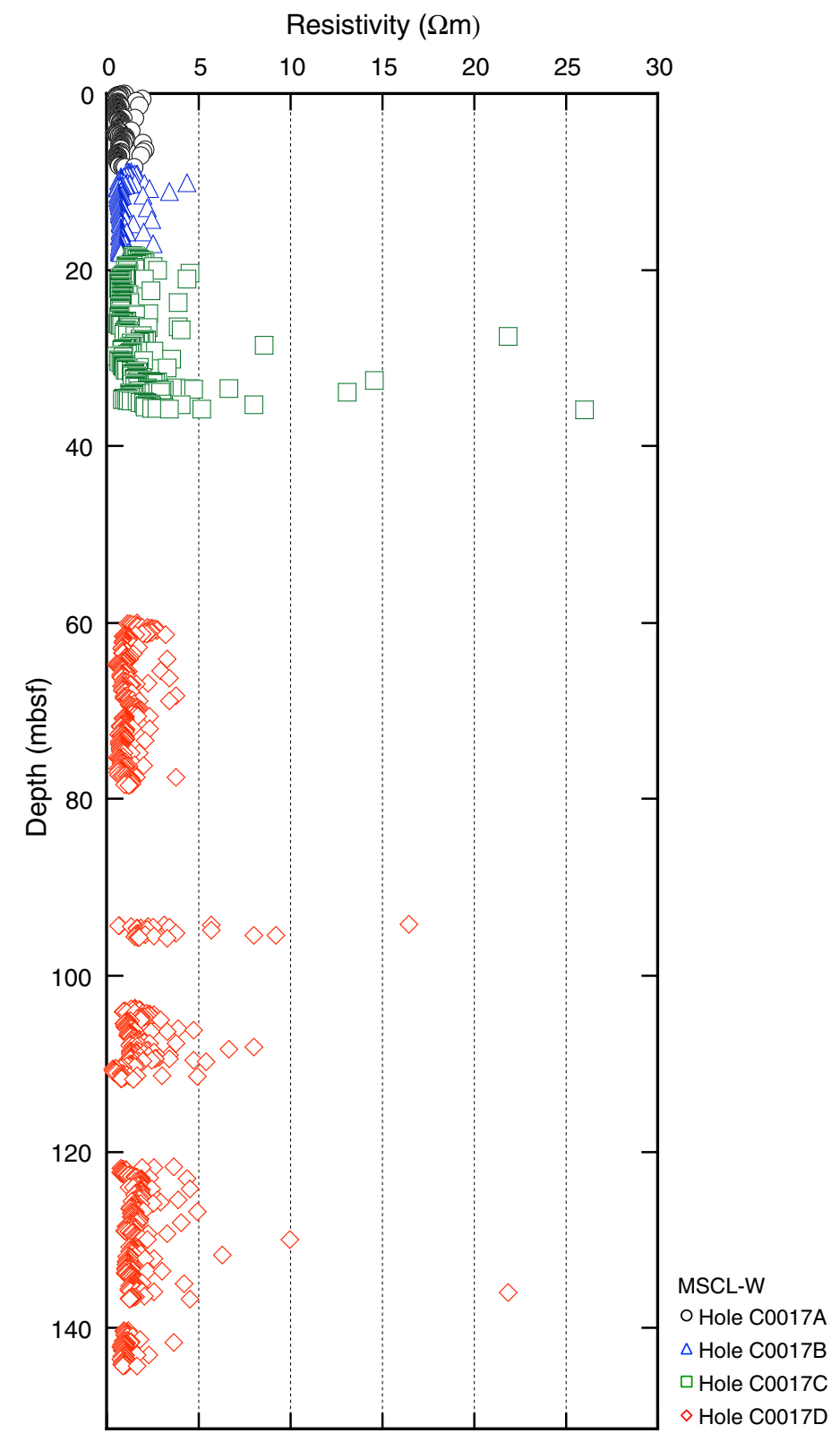


Table T1. Coring summary, Site C0017. (Continued on next page.)

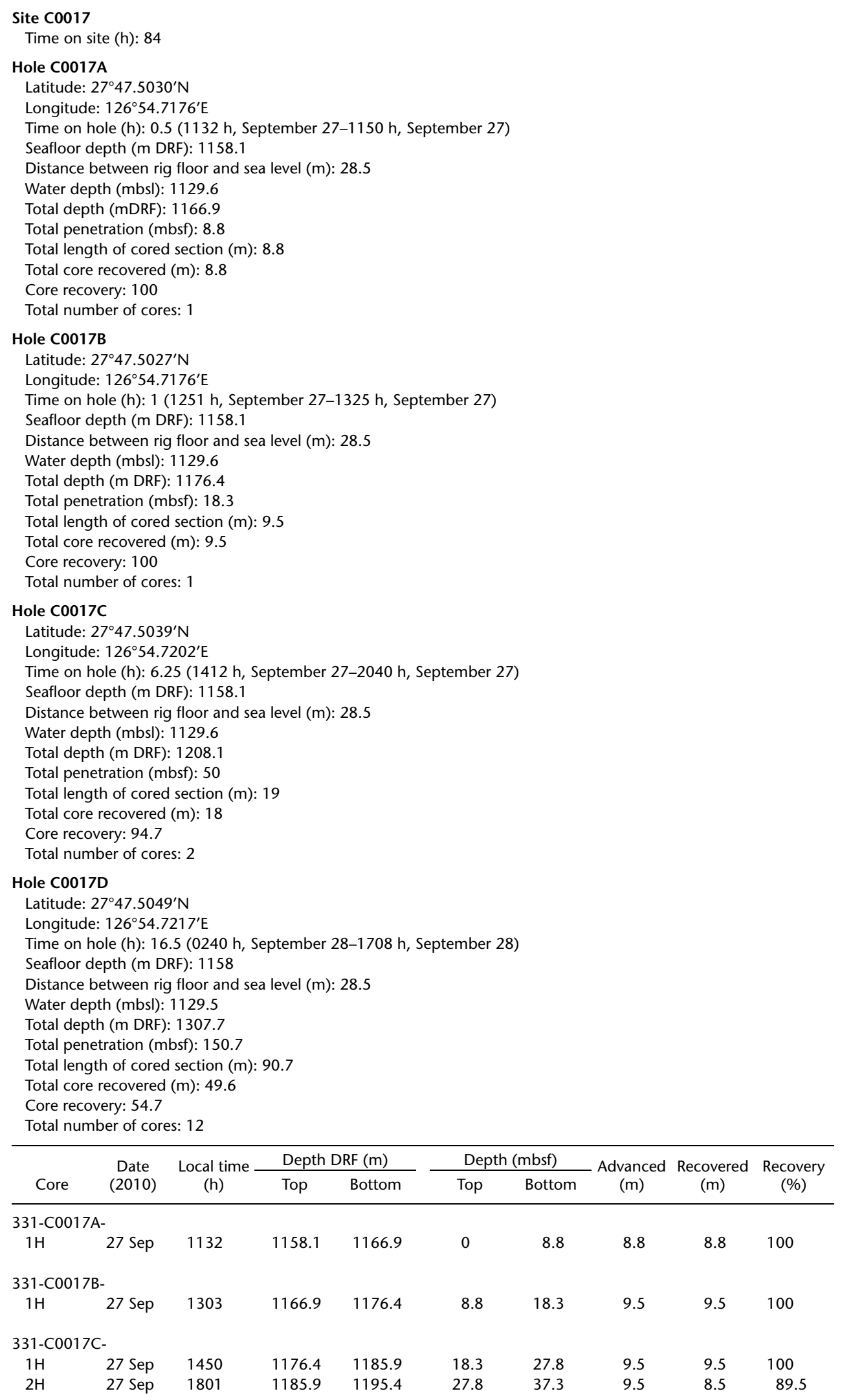


Table T1 (continued).

\begin{tabular}{|c|c|c|c|c|c|c|c|c|c|}
\hline \multirow[b]{2}{*}{ Core } & \multirow{2}{*}{$\begin{array}{l}\text { Date } \\
\text { (2010) }\end{array}$} & \multirow{2}{*}{$\begin{array}{l}\text { Local time } \\
\text { (h) }\end{array}$} & \multicolumn{2}{|c|}{ Depth DRF (m) } & \multicolumn{2}{|c|}{ Depth (mbsf) } & \multirow{2}{*}{$\begin{array}{c}\text { Advanced } \\
\text { (m) }\end{array}$} & \multirow{2}{*}{$\begin{array}{l}\text { Recovered } \\
(\mathrm{m})\end{array}$} & \multirow{2}{*}{$\begin{array}{c}\text { Recovery } \\
\text { (\%) }\end{array}$} \\
\hline & & & Top & Bottom & Top & Bottom & & & \\
\hline \multicolumn{10}{|c|}{ 331-C0017D- } \\
\hline $1 \mathrm{H}$ & $28 \mathrm{Sep}$ & 0628 & 1218 & 1227.2 & 60 & 69.2 & 9.2 & 9.2 & 100 \\
\hline $2 \mathrm{H}$ & $28 \mathrm{Sep}$ & 0915 & 1227.2 & 1236.7 & 69.2 & 78.7 & 9.5 & 9 & 94.7 \\
\hline $3 \mathrm{H}$ & $28 \mathrm{Sep}$ & 1205 & 1236.7 & 1242.7 & 78.7 & 84.7 & 6 & 0 & 0 \\
\hline $4 \mathrm{H}$ & $28 \mathrm{Sep}$ & 1423 & 1242.7 & 1242.7 & 84.7 & 84.7 & 0 & 0 & 0 \\
\hline $5 T$ & $28 \mathrm{Sep}$ & 1720 & 1242.7 & 1252.7 & 84.7 & 94.2 & 9.5 & 0 & 0 \\
\hline $6 X$ & $28 \mathrm{Sep}$ & 2039 & 1252.2 & 1261.7 & 94.2 & 103.7 & 9.5 & 1.8 & 18.9 \\
\hline $7 \mathrm{H}$ & 29 Sep & 0042 & 1261.7 & 1270.2 & 103.7 & 112.2 & 8.5 & 8.5 & 100 \\
\hline $8 \mathrm{~T}$ & 29 Sep & 0248 & 1270.2 & 1279.7 & 112.2 & 121.7 & 9.5 & 0.09 & 0.9 \\
\hline $9 \mathrm{X}$ & 29 Sep & 0457 & 1279.7 & 1288.7 & 121.7 & 130.7 & 9 & 9.7 & 107.8 \\
\hline $10 x$ & 29 Sep & 0740 & 1288.7 & 1298.2 & 103.7 & 140.2 & 9.5 & 6.5 & 68.4 \\
\hline $11 \mathrm{X}$ & 29 Sep & 0944 & 1298.2 & 1307.7 & 140.2 & 149.7 & 9.5 & 4.8 & 50.5 \\
\hline $12 \mathrm{H}$ & $30 \mathrm{Sep}$ & 0029 & 1307.7 & 1308.7 & 149.7 & 150.7 & 1 & 0 & 0 \\
\hline
\end{tabular}

DRF = drilling depth below rig floor. $\mathrm{H}=\mathrm{HPCS}, \mathrm{T}=\mathrm{EPCS}, \mathrm{X}=\mathrm{ESCS}$. 
Table T2. Lithological units, Site C0017.

\begin{tabular}{|c|c|c|c|c|c|}
\hline \multirow{2}{*}{$\begin{array}{l}\text { Lithological } \\
\text { unit }\end{array}$} & \multirow[b]{2}{*}{ Description } & \multirow[b]{2}{*}{ Hole, core, section, interval $(\mathrm{cm})$} & \multicolumn{2}{|c|}{ Depth (mbsf) } & \multirow{2}{*}{$\begin{array}{l}\text { Thickness } \\
\text { (m) }\end{array}$} \\
\hline & & & Top & Bottom & \\
\hline \multirow{3}{*}{ I } & & $331-$ & & & \\
\hline & Dominantly massive hemipelagic mud, with minor pumice gravel and volcaniclastic sediment & C0017A-1H-1, 0, to $1 \mathrm{H}-\mathrm{CC}, 21.5$ & 0 & 8.635 & 8.635 \\
\hline & & C0017B-1H-1, 0, to $1 \mathrm{H}-\mathrm{CC}, 21$ & 8.8 & 18.505 & 9.705 \\
\hline II & Dominantly pumiceous gravel, with minor hemipelagic mud and volcaniclastic sediment & $\mathrm{C} 0017 \mathrm{C}-1 \mathrm{H}-1,80$, to $2 \mathrm{H}-\mathrm{CC}, 28$ & 19.1 & 36.17 & 17.07 \\
\hline III & Dominantly pumiceous gravel, with minor hemipelagic mud and volcaniclastic sediment & C0017D-1H-1, 115, to $2 \mathrm{H}-\mathrm{CC}, 20$ & 61.15 & 78.82 & 17.67 \\
\hline IV & Hemipelagic mud, pumice breccia, volcaniclastic sediment & C0017D-6X-1, 15 , to $11 \mathrm{X}-\mathrm{CC}, 40.5$ & 94.35 & 144.745 & 49.7 \\
\hline
\end{tabular}

Table T3. Interpreted results of X-ray diffraction (XRD) analyses of samples, Site C0017. (Continued on next page.)

\begin{tabular}{|c|c|c|c|c|}
\hline $\begin{array}{l}\text { Sample } \\
\text { number }\end{array}$ & $\begin{array}{l}\text { Core, section, } \\
\text { interval }(\mathrm{cm})\end{array}$ & Lithology & Subsampled for & Result \\
\hline & 331-C0017A- & & & \\
\hline 35247 & $1 \mathrm{H}-1,11-11.5$ & Dark brown volcanic glass & XRD only—check mineralogy & Glass, anorthite, augite ??? \\
\hline 35293 & $1 \mathrm{H}-1,35.5-37.5$ & Olive-green mud/clay & Routine chemistry & Calcite, quartz, muscovite, anorthite, chlorite \\
\hline 35295 & $1 \mathrm{H}-1,119-120$ & Light gray pumice & Routine chemistry & Glass, halite, quartz \\
\hline 35296 & $1 \mathrm{H}-2,76.5-78.5$ & Olive-green mud/clay & Routine chemistry & Quartz, calcite, anorthite, muscovite, chlorite \\
\hline 35299 & $1 \mathrm{H}-3,54-56$ & Black volcanic sediment & Routine chemistry & Glass, calcite, quartz, albite, muscovite (trace) \\
\hline 35300 & $1 \mathrm{H}-4,122-124$ & Calcareous sand & Routine chemistry & Calcite, quartz, halite, anorthite \\
\hline 35303 & $1 \mathrm{H}-5,115-117$ & Olive-green mud/clay & Routine chemistry & Quartz, calcite, muscovite, chlorite, anorthite \\
\hline 35306 & $1 \mathrm{H}-6,62-64$ & Olive-green mud/clay & Routine chemistry & Quartz, calcite, muscovite, anorthite, chlorite \\
\hline \multirow[t]{2}{*}{35308} & $1 \mathrm{H}-\mathrm{CC}, 16-17$ & Pumice & XRD only—check mineralogy & Glass, anorthite \\
\hline & 331-C0017B- & & & \\
\hline 35419 & $1 \mathrm{H}-1,10-11$ & Pumice & XRD only—check mineralogy & Glass, quartz, anorthite \\
\hline 35420 & $1 \mathrm{H}-1,103-105$ & Olive-green mud/clay & Routine chemistry & Quartz, calcite, muscovite, anorthite, dolomite, chlorite \\
\hline 35422 & $1 \mathrm{H}-2,21-22$ & Black pumice clast & XRD only—check mineralogy & Glass, anorthite \\
\hline 35423 & $1 \mathrm{H}-3,80-82$ & Olive-green mud/clay & Routine chemistry & Quartz, calcite, anorthite, muscovite, chlorite \\
\hline 35426 & $1 \mathrm{H}-4,80-82$ & Olive-green mud/clay & Routine chemistry & Quartz, calcite, muscovite, anorthite, dolomite, chlorite \\
\hline 35428 & $1 \mathrm{H}-5,80-82$ & Olive-green mud/clay & Routine chemistry & Quartz, calcite, anorthite, muscovite, chlorite \\
\hline 35429 & $1 \mathrm{H}-6,57-59$ & Calcareous gravel, olive-green & Routine chemistry & Glass, calcite, quartz, anorthite \\
\hline \multirow[t]{2}{*}{35432} & $1 \mathrm{H}-7,80-82$ & Olive-green mud/clay & Routine chemistry & Quartz, calcite, muscovite, anorthite, dolomite, chlorite \\
\hline & 331-C0017C- & & & \\
\hline 35441 & $1 \mathrm{H}-1,114-116$ & Olive-green mud/clay & Routine chemistry & Calcite, quartz, halite, anorthite, muscovite, chlorite (trace) \\
\hline 35443 & $1 \mathrm{H}-2,118-120$ & Olive-green mud/clay & Routine chemistry & Calcite, quartz, anorthite, muscovite, chlorite \\
\hline 35445 & $1 \mathrm{H}-3,70-72$ & Olive-green mud/clay & Routine chemistry & Calcite, quartz, anorthite, muscovite, chlorite, cristobalite \\
\hline 35447 & $1 \mathrm{H}-4,64-66$ & Olive-green sandy clay & Routine chemistry & Quartz, anorthite, microcline, calcite, dolomite, muscovite \\
\hline 35449 & $1 \mathrm{H}-5,60-62$ & Olive-green mud/clay & Routine chemistry & Quartz, calcite, anorthite, muscovite, chlorite \\
\hline 35451 & $1 \mathrm{H}-6,97-99$ & Oxidized yellow-brown pumiceous clay & Routine chemistry & Calcite, quartz, muscovite, anorthite, halite, chlorite (trace) \\
\hline 35453 & $1 \mathrm{H}-7,73-75$ & Oxidized yellow-brown pumiceous gravel & Routine chemistry & Glass, quartz, halite \\
\hline 35455 & $2 \mathrm{H}-1,90-92$ & Oxidized yellow-brown pumiceous gravel & Routine chemistry & Glass, quartz, halite \\
\hline 35457 & $2 \mathrm{H}-2,97-99$ & Oxidized yellow-brown sandy clay & Routine chemistry & Calcite, quartz, anorthite, muscovite, cristobalite, chlorite \\
\hline 35459 & $2 \mathrm{H}-3,30-32$ & Oxidized yellow-brown pumiceous gravel & Routine chemistry & Glass, quartz, halite \\
\hline 35461 & $2 \mathrm{H}-4,84-86$ & Pumiceous gravel & Routine chemistry & Glass, halite \\
\hline 35463 & $2 \mathrm{H}-5,50-52$ & Pumiceous gravel & Routine chemistry & Glass, halite \\
\hline 35465 & $2 \mathrm{H}-6,60-62$ & Pumiceous gravel & Routine chemistry & Glass, halite \\
\hline
\end{tabular}


Table T3 (continued).

\begin{tabular}{|c|c|c|c|c|}
\hline $\begin{array}{l}\text { Sample } \\
\text { number }\end{array}$ & $\begin{array}{l}\text { Core, section, } \\
\text { interval }(\mathrm{cm})\end{array}$ & Lithology & Subsampled for & Result \\
\hline 35467 & $2 \mathrm{H}-7,45-47$ & Pumiceous gravel & Routine chemistry & Glass, halite \\
\hline & 331-C0017D- & & & \\
\hline 35561 & $1 \mathrm{H}-1,131-133$ & Gray pumiceous gravel & Routine chemistry & Glass, halite \\
\hline 35564 & $1 \mathrm{H}-2,99-101$ & Pumiceous gravel with minor olive clay & Routine chemistry & Glass, quartz, halite \\
\hline 35565 & $1 \mathrm{H}-3,121-123$ & Pumiceous gravel with minor olive clay & Routine chemistry & Glass, quartz, halite, anorthite \\
\hline 35568 & $1 \mathrm{H}-4,29-31$ & Pumiceous gravel with olive clay & Routine chemistry & Glass, quartz, halite, anorthite \\
\hline 35567 & $1 \mathrm{H}-4,86-87$ & Dark green (glauconitic?) stained pumice & XRD only_identify green stain & Glass, halite, quartz (trace) \\
\hline 35572 & $1 \mathrm{H}-5,48-50$ & Pumiceous gravel with olive clay & Routine chemistry & Quartz, glass, anorthite, muscovite, halite \\
\hline 35575 & $1 \mathrm{H}-6,26-28$ & Indurated pale green clay & Routine chemistry & Glass, quartz, halite, anorthite, muscovite (trace) \\
\hline 35576 & $1 \mathrm{H}-7,30-32$ & Volcaniclastic sand & Routine chemistry & Quartz, anorthite, microcline, halite, muscovite \\
\hline 35583 & $2 \mathrm{H}-1,120-122$ & Gray pumiceous gravel & Routine chemistry & Glass, halite, anorthite, quartz \\
\hline 35586 & $2 \mathrm{H}-2,112-114$ & Light brown clay & Routine chemistry & Quartz, anorthite, muscovite, chlorite (trace) \\
\hline 35587 & $2 \mathrm{H}-3,61-62$ & Mica-rich sand & XRD only & Quartz, anorthite, microcline, muscovite, brindleyite (Ni-Al silicate) ??? \\
\hline 35588 & $2 \mathrm{H}-3,52-54$ & Olive-green clay & Routine chemistry & Quartz, anorthite, microcline, muscovite \\
\hline 35591 & $2 \mathrm{H}-4,51.5-53.5$ & Gray/Dark green pumiceous gravel & Routine chemistry & Glass, halite, anorthite, microcline \\
\hline 35592 & $2 \mathrm{H}-5,65.5-67.5$ & Volcaniclastic sand & Routine chemistry & Glass, halite, anorthite \\
\hline 35594 & $2 \mathrm{H}-5,78-79$ & Indurated olive-green clay & XRD only & Quartz, anorthite, muscovite, chlorite \\
\hline 35595 & $2 \mathrm{H}-6,62-64$ & Dark gray indurated clay & Routine chemistry & Glass, quartz, anorthite, muscovite, halite, chlorite \\
\hline 35598 & $2 \mathrm{H}-7,81.5-83.5$ & Gray pumice with green clay & Routine chemistry & Glass, anorthite, quartz, halite \\
\hline 35599 & $2 \mathrm{H}-\mathrm{CC}, 6-7$ & Black volcanic glass fragment & Routine chemistry & Glass, anorthite \\
\hline 35651 & $6 X-1,63-65$ & Brown clay-fizzes with $\mathrm{HCl}$ & Routine chemistry & Quartz, anorthite, dolomite, microcline, muscovite, chlorite \\
\hline 35653 & $6 \mathrm{X}-2,16-18$ & Brown clay-fizzes with $\mathrm{HCl}$ & Routine chemistry & Quartz, anorthite, calcite, muscovite, chlorite \\
\hline 35694 & $7 \mathrm{H}-2,30-32$ & Gray indurated calcareous clay & Routine chemistry & Quartz, anorthite, calcite, microcline, muscovite, chlorite \\
\hline 35696 & 7H-3, 134-136 & Silt with gray calcareous clay & Routine chemistry & Quartz, anorthite, calcite, microcline, muscovite, chlorite, tremolite ??? \\
\hline 35698 & $7 \mathrm{H}-4,110-112$ & Gray indurated calcareous clay & Routine chemistry & Quartz, anorthite, microcline, muscovite, chlorite \\
\hline 35700 & $7 \mathrm{H}-5,42-44$ & Brown volcaniclastic silt & Routine chemistry & Glass, quartz, anorthite, pyrite \\
\hline 35702 & $7 \mathrm{H}-6,66-68$ & Slightly soupy gray calcareous clay & Routine chemistry & Quartz, anorthite, calcite, microcline, dolomite, muscovite, chlorite \\
\hline 35706 & $7 \mathrm{H}-\mathrm{CC}, 22-24$ & Gray indurated calcareous clay and silt & Routine chemistry & Quartz, anorthite, microcline, muscovite, chlorite \\
\hline 35704 & $8 \mathrm{~T}-\mathrm{CC}, 0-2$ & Redrill-flow-banded welded tuff & Routine chemistry & Glass, anorthite, microcline \\
\hline 35731 & $9 X-2,110-112$ & Gray indurated calcareous clay & Routine chemistry & Quartz, anorthite, calcite, microcline, muscovite, chlorite \\
\hline 35733 & $9 X-4,100-102$ & Gray indurated calcareous clay & Routine chemistry & Quartz, anorthite, calcite, microcline, dolomite, muscovite, chlorite \\
\hline 35735 & $9 \mathrm{X}-6,100-102$ & Gray indurated calcareous clay & Routine chemistry & Quartz, anorthite, calcite, microcline, muscovite, chlorite \\
\hline 35737 & $9 X-8,70-72$ & Gray indurated calcareous clay & Routine chemistry & Quartz, anorthite, calcite, microcline, muscovite, chlorite \\
\hline 35739 & $9 \mathrm{X}-\mathrm{CC}, 40-42$ & Dark brown sugary pumice & XRD only & Glass, quartz, anorthite, pyrite \\
\hline 35780 & $10 X-2,60-62$ & Dark gray calcareous clayey silt & Routine chemistry & Quartz, anorthite, dolomite, microcline, muscovite, chlorite \\
\hline 35782 & $10 \times-4,32-34$ & Gray indurated calcareous clay & Routine chemistry & Quartz, anorthite, calcite, microcline, dolomite, muscovite, chlorite \\
\hline 35784 & $10 \mathrm{X}-\mathrm{CC}, 40-42$ & Gray indurated calcareous clay & Routine chemistry & Quartz, anorthite, calcite, microcline, muscovite, chlorite \\
\hline 35892 & $11 \mathrm{X}-1,70-72$ & Brown calcareous clay & Routine chemistry & Quartz, anorthite, calcite, microcline, dolomite, muscovite, chlorite \\
\hline 35894 & $11 X-2,68-70$ & Brown calcareous clay & Routine chemistry & Quartz, anorthite, dolomite, microcline, muscovite, chlorite \\
\hline 35898 & $11 \times-3,27-29$ & White-gray hydrothermal? grit & XRD only & Glass, halite, quartz, sylvite \\
\hline 35896 & $11 X-3,75-77$ & Brown calcareous clay & Routine chemistry & Quartz, anorthite, muscovite, chlorite \\
\hline 35900 & $11 \mathrm{X}-\mathrm{CC}, 33-35$ & White-gray hydrothermal? grit & Routine chemistry & Glass, quartz, anorthite \\
\hline
\end{tabular}

Phases listed in approximate order of decreasing abundance. 
Table T4. Dry mass and light microscopic observations of micropaleontology samples, Site C0017.

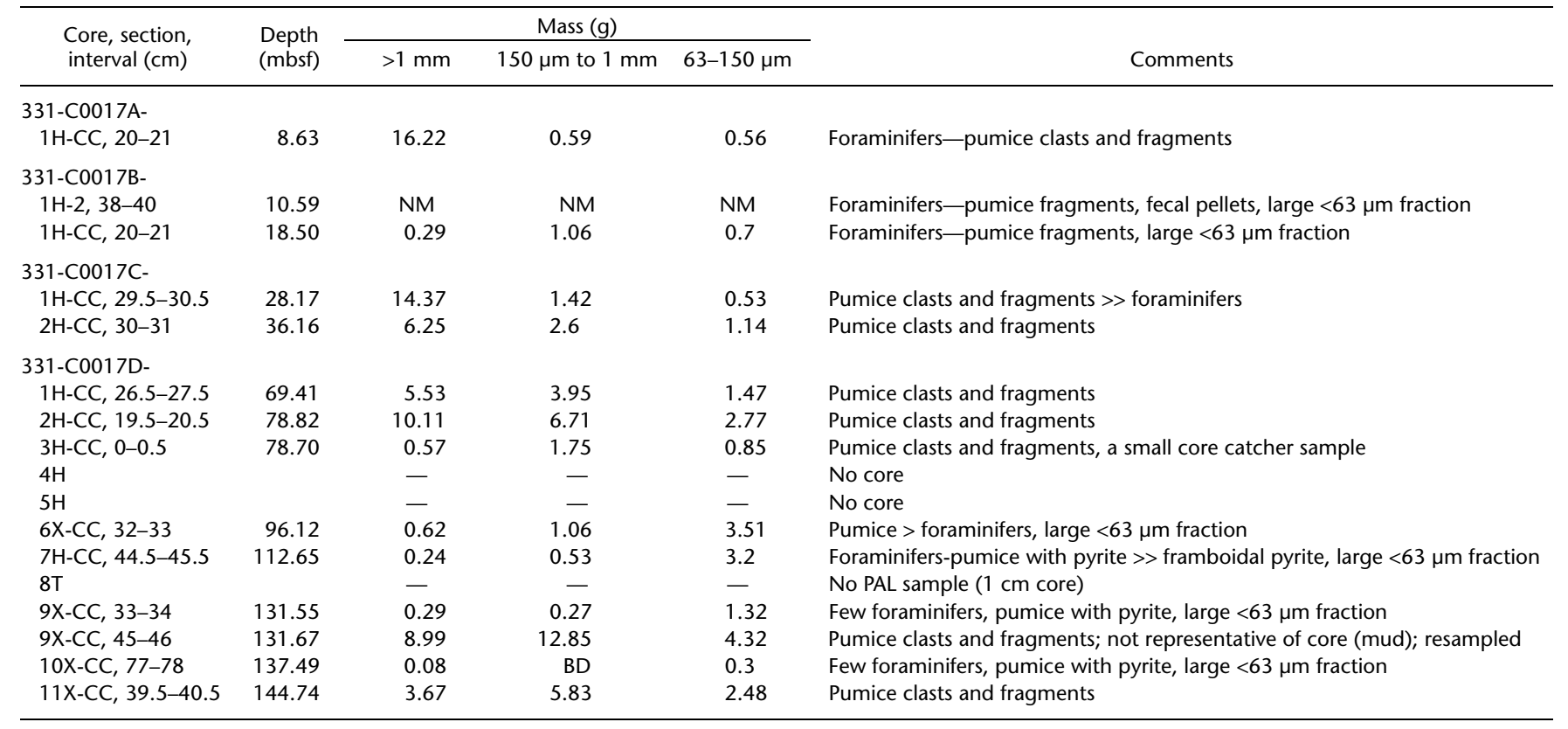

$\mathrm{NM}=$ not measured. $-=$ no data. $\mathrm{BD}=$ below detection. $\mathrm{PAL}=$ paleontology.

Table T5. Foraminifers: micropaleontological observations, Site C0017. This table is available in an oversized format. 
Table T6. Chemical composition of interstitial pore water, Site C0017. (Continued on next page.)

\begin{tabular}{|c|c|c|c|c|c|c|c|c|c|c|c|c|c|c|c|c|c|}
\hline $\begin{array}{l}\text { Core, section, } \\
\text { interval }(\mathrm{cm})\end{array}$ & $\begin{array}{l}\text { Depth } \\
\text { (mbsf) }\end{array}$ & $\begin{array}{l}\text { Volume } \\
(\mathrm{mL})\end{array}$ & $\begin{array}{l}\text { Refractive } \\
\text { index }\end{array}$ & $\mathrm{pH}$ & $\begin{array}{l}\text { Alkalinity } \\
(\mathrm{mM})\end{array}$ & $\underset{(\mathrm{mM})}{\mathrm{Cl}}$ & $\begin{array}{c}\text { Phosphate } \\
\quad(\mu \mathrm{M})\end{array}$ & $\begin{array}{c}\mathrm{NH}_{4} \\
(\mathrm{mM})\end{array}$ & $\begin{array}{c}\mathrm{Si} \\
(\mathrm{mM})^{*}\end{array}$ & $\begin{array}{c}\mathrm{Br} \\
(\mathrm{mM})\end{array}$ & $\begin{array}{c}\mathrm{SO}_{4} \\
(\mathrm{mM})\end{array}$ & $\begin{array}{c}\mathrm{Na} \\
(\mathrm{mM})\end{array}$ & $\mathrm{Na}_{\text {charge }}$ & $\begin{array}{l}\text { Difference } \\
\text { (\%) }\end{array}$ & $\mathrm{Na} / \mathrm{Cl}$ & $\underset{(\mathrm{mM})}{\mathrm{K}}$ & $\begin{array}{c}\mathrm{Mg} \\
(\mathrm{mM})\end{array}$ \\
\hline \multicolumn{18}{|l|}{ 331-C0017A- } \\
\hline $1 \mathrm{H}-1,80-90$ & 0.80 & 36.0 & 1.33936 & 7.5 & 3.237 & 540.5 & 17.3 & 0.02 & 0.62 & 0.829 & 28.43 & 466 & 469 & 0.62 & 0.862 & 11.8 & 50.1 \\
\hline $1 \mathrm{H}-5,88-98$ & 6.52 & 40.5 & 1.33935 & 7.5 & 4.313 & 543.9 & 10.9 & 0.18 & 0.61 & 0.852 & 27.97 & 471 & 470 & 0.22 & 0.865 & 11.6 & 51.5 \\
\hline \multicolumn{18}{|l|}{ 331-C0017B- } \\
\hline $1 \mathrm{H}-2,85-95$ & 11.06 & 53.0 & 1.33934 & 7.47 & 6.993 & 543.1 & 24.7 & 0.45 & 0.79 & 0.834 & 26.15 & 471 & 471 & 0.08 & 0.867 & 11.5 & 50.1 \\
\hline $1 \mathrm{H}-5,70-80$ & 15.14 & 57.0 & 1.33934 & 7.56 & 7.340 & 542.9 & 17.6 & 0.45 & 0.71 & 0.851 & 25.79 & 477 & 470 & 1.41 & 0.878 & 11.0 & 50.4 \\
\hline \multicolumn{18}{|l|}{ 331-C0017C- } \\
\hline $1 \mathrm{H}-2,60-70$ & 20.31 & 58.0 & 1.33934 & 7.34 & 5.136 & 545.5 & 11.1 & 0.21 & 0.58 & 0.816 & 26.68 & 468 & 470 & 0.45 & 0.858 & 11.2 & 50.9 \\
\hline $1 \mathrm{H}-5,115-125$ & 25.09 & 59.0 & 1.33936 & 7.41 & 3.205 & 546.6 & 4.6 & BD & 0.45 & 0.851 & 28.86 & 474 & 469 & 1.06 & 0.867 & 11.4 & 53.0 \\
\hline $2 \mathrm{H}-1,65-75$ & 28.45 & 58.0 & 1.33930 & 7.68 & 2.340 & 541.7 & 1.9 & BD & 0.19 & 0.840 & 28.87 & 465 & 467 & 0.59 & 0.858 & 10.2 & 51.9 \\
\hline $2 \mathrm{H}-2,65-75$ & 29.85 & 55.0 & 1.33935 & 7.41 & 2.668 & 543.1 & 2.4 & BD & 0.19 & 0.865 & 29.15 & 468 & 469 & 0.25 & 0.862 & 11.5 & 51.7 \\
\hline \multicolumn{18}{|l|}{ 331-C0017D- } \\
\hline $1 \mathrm{H}-3,80-90$ & 63.62 & 32.5 & 1.33936 & 7.27 & 2.984 & 550.1 & 0.7 & BD & 0.79 & 0.858 & 29.49 & 462 & 478 & 3.24 & 0.840 & 10.0 & 51.8 \\
\hline $1 \mathrm{H}-5.80-90$ & 66.44 & 28.5 & 1.33937 & 7.36 & 3.118 & 550.2 & 1.4 & BD & 0.76 & 0.763 & 25.09 & 470 & 466 & 0.83 & 0.855 & 10.2 & 52.8 \\
\hline $1 \mathrm{H}-6,110-120$ & 68.15 & 30.5 & 1.33936 & 7.45 & 3.064 & 543.3 & 1.2 & BD & 0.79 & 0.844 & 27.77 & 465 & 467 & 0.44 & 0.856 & 9.8 & 52.2 \\
\hline $2 \mathrm{H}-5,30-40$ & 75.15 & 37.5 & 1.33935 & 7.43 & 3.001 & 551.1 & 0.9 & BD & 0.91 & 0.862 & 29.26 & 465 & 475 & 2.08 & 0.844 & 8.9 & 53.5 \\
\hline $6 X-1,66-76$ & 94.86 & 19.5 & 1.33941 & 7.78 & 5.694 & 550.7 & 0.6 & 0.07 & 0.41 & 0.883 & 29.65 & 464 & 472 & 1.68 & 0.843 & 7.1 & 53.5 \\
\hline $7 \mathrm{H}-2,112-122$ & 106.23 & 16.5 & 1.33940 & - & - & 547.7 & - & 0.06 & 0.43 & 0.825 & 27.01 & 461 & 460 & 0.23 & 0.842 & 7.1 & 52.6 \\
\hline $7 \mathrm{H}-4,42-52$ & 108.34 & 14.3 & 1.33941 & 7.67 & 5.346 & 550.5 & 0.4 & 0.05 & 0.38 & 0.860 & 28.99 & 465 & 469 & 0.83 & 0.845 & 6.6 & 54.3 \\
\hline 7H-5, 80-90 & 110.14 & 24.5 & 1.33941 & 7.4 & 4.618 & 554.2 & 1.0 & 0.04 & 0.59 & 0.886 & 29.53 & 459 & 479 & 4.15 & 0.828 & 7.2 & 52.2 \\
\hline $9 X-5,25-35$ & 126.13 & 25.5 & - & 7.44 & 5.409 & 549.2 & 0.3 & BD & 0.30 & 0.867 & 28.37 & 464 & 471 & 1.49 & 0.844 & 7.0 & 49.1 \\
\hline $9 X-8,75-90$ & 130.86 & 14.0 & 1.33954 & 7.88 & 6.390 & 555.2 & 0.5 & BD & 0.28 & 0.867 & 28.48 & 461 & 476 & 3.07 & 0.830 & 7.0 & 51.6 \\
\hline 10X-1, 88-102 & 131.58 & 11.5 & - & 7.77 & 4.524 & 546.3 & 0.9 & BD & 0.79 & 0.872 & 29.52 & 460 & 463 & 0.61 & 0.842 & 7.4 & 55.6 \\
\hline $10 X-4,101-121$ & 135.95 & 27.0 & 1.33949 & 7.58 & 6.117 & 556.1 & 1.2 & BD & 0.27 & 0.836 & 27.41 & 461 & 477 & 3.25 & 0.830 & 7.9 & 50.2 \\
\hline $11 X-1,80-90$ & 141.00 & 22.0 & - & 7.41 & 5.631 & 549.2 & 0.6 & 0.09 & 0.27 & 0.850 & 27.77 & 478 & 469 & 1.95 & 0.871 & 10.2 & 49.2 \\
\hline Bottom water & & & & & 2.04 & 543 & & & & 0.836 & 28.08 & 466 & & & 0.859 & 10.15 & 52.5 \\
\hline
\end{tabular}

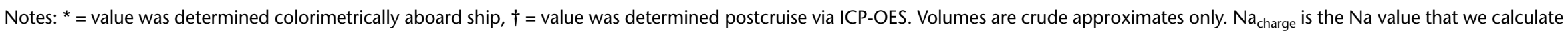

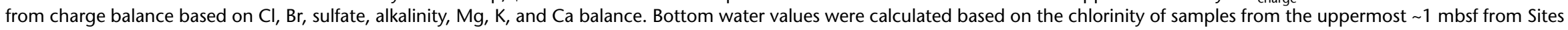
$\mathrm{C} 0014, \mathrm{C} 0015$, and $\mathrm{C} 0017(n=4)$ and assuming that the elements are in constant proportion to chloride; we also make the assumption that chlorinity and chloride are the same. $\mathrm{BD}=$ below

detection limit, $-=$ no data. 


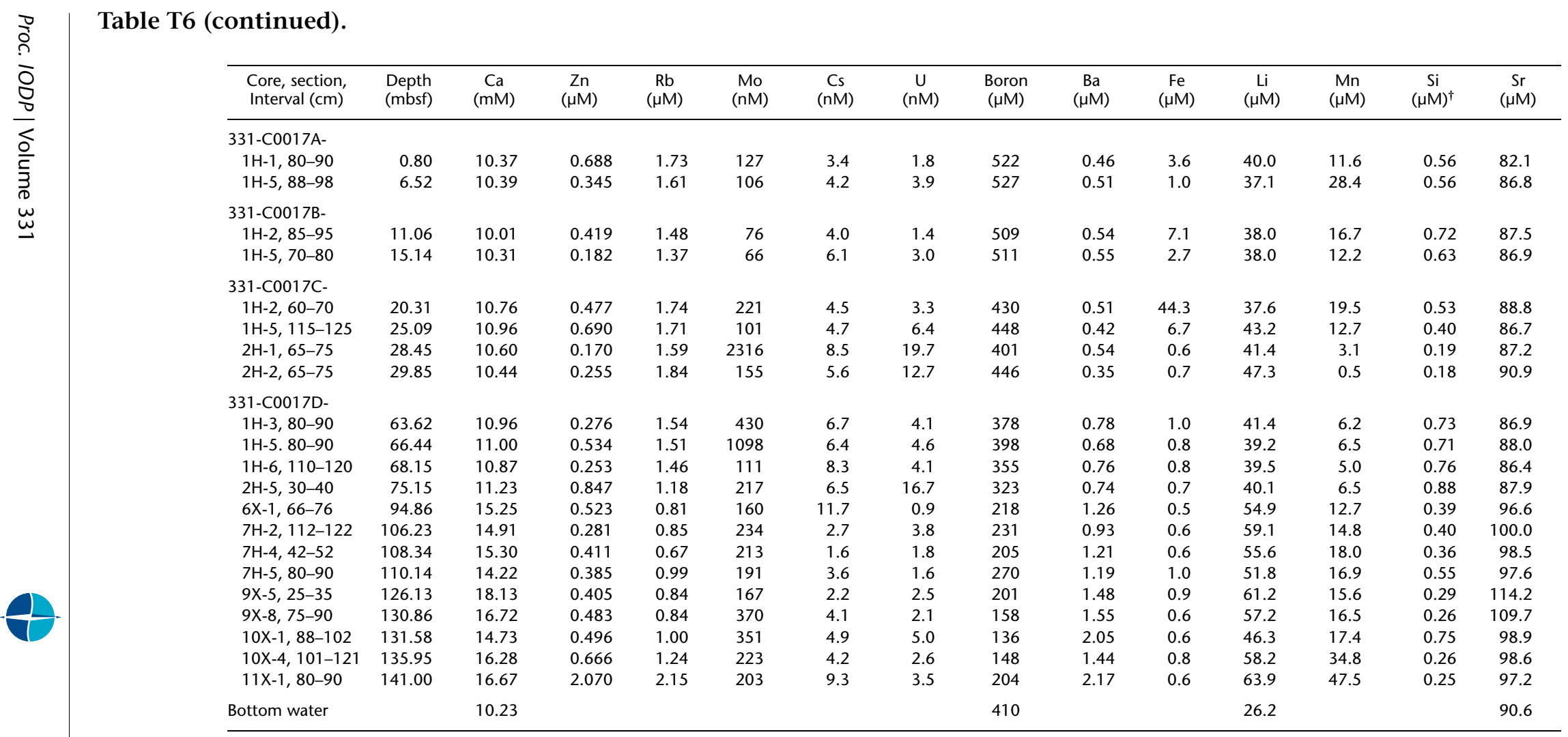


Table T7. Concentrations of hydrocarbons observed in safety gas vials, Site C0017.

\begin{tabular}{|c|c|c|c|c|c|c|c|}
\hline $\begin{array}{l}\text { Core, section, } \\
\text { interval }(\mathrm{cm})\end{array}$ & $\begin{array}{l}\text { Depth } \\
\text { (mbsf) }\end{array}$ & $\begin{array}{c}\mathrm{CH}_{4} \text { in } \\
\text { headspace } \\
(\mathrm{ppm})\end{array}$ & $\begin{array}{c}\mathrm{C}_{2} \mathrm{H}_{6} \text { in } \\
\text { headspace } \\
(\mathrm{ppm})\end{array}$ & $\begin{array}{c}\mathrm{C}_{3} \mathrm{H}_{8} \text { in } \\
\text { headspace } \\
\text { (ppm) }\end{array}$ & $\begin{array}{c}\text { Butane, ethylene, } \\
\text { and/or propylene } \\
\text { ( } \mathrm{\text {or } N})\end{array}$ & $\begin{array}{l}\text { Sediment } \\
\text { mass } \\
\text { (g) }\end{array}$ & $\begin{array}{l}\mathrm{CH}_{4} \text { in } \\
\text { pore water } \\
(\mu \mathrm{M})\end{array}$ \\
\hline $\begin{array}{l}331-\mathrm{C} 0017 \mathrm{~A}- \\
1 \mathrm{H}-1,136-140\end{array}$ & 1.36 & 2.16 & $\mathrm{BD}$ & $\mathrm{BD}$ & $\mathrm{N}$ & 7.295 & 0.4 \\
\hline $\begin{array}{l}331-\mathrm{C} 0017 \mathrm{~B}- \\
1 \mathrm{H}-1,136.5-140.5\end{array}$ & 10.17 & 2.42 & $\mathrm{BD}$ & $\mathrm{BD}$ & $\mathrm{N}$ & 4.692 & 0.4 \\
\hline $\begin{array}{l}331-\mathrm{C} 0017 \mathrm{C}- \\
1 \mathrm{H}-1,137-141 \\
2 \mathrm{H}-1,136-140\end{array}$ & $\begin{array}{l}19.67 \\
29.16\end{array}$ & $\begin{array}{l}2.48 \\
2.10\end{array}$ & $\begin{array}{l}\mathrm{BD} \\
\mathrm{BD}\end{array}$ & $\begin{array}{l}\mathrm{BD} \\
\mathrm{BD}\end{array}$ & $\begin{array}{l}\mathrm{N} \\
\mathrm{N}\end{array}$ & $\begin{array}{l}5.571 \\
6.921\end{array}$ & $\begin{array}{l}0.2 \\
0.4\end{array}$ \\
\hline 331-C0017D- & & & & & & & \\
\hline $\begin{array}{l}1 \mathrm{H}-1,137-141 \\
2 \mathrm{H}-1,137-141\end{array}$ & $\begin{array}{l}61.37 \\
70.57\end{array}$ & $\begin{array}{l}1.15 \\
2.22\end{array}$ & $\begin{array}{l}\mathrm{BD} \\
\mathrm{BD}\end{array}$ & $\begin{array}{l}B D \\
B D\end{array}$ & $\begin{array}{l}\mathrm{N} \\
\mathrm{N}\end{array}$ & $\begin{array}{l}2.285 \\
3.331\end{array}$ & $\begin{array}{l}1.0 \\
0.6\end{array}$ \\
\hline $6 X-1,124-128$ & 95.44 & 2.80 & $\mathrm{BD}$ & $\mathrm{BD}$ & $\mathrm{N}$ & 6.788 & 0.2 \\
\hline $7 \mathrm{H}-2,137-141$ & 106.48 & 2.76 & $\mathrm{BD}$ & $\mathrm{BD}$ & $\mathrm{N}$ & 5.099 & 0.2 \\
\hline $8 \mathrm{~T}-\mathrm{CC}, 5-9$ & 112.25 & 3.84 & $\mathrm{BD}$ & BD & $\mathrm{N}$ & 0.693 & 3.4 \\
\hline $9 X-3,0-4$ & 123.13 & 2.12 & $\mathrm{BD}$ & $\mathrm{BD}$ & $\mathrm{N}$ & 6.121 & 0.2 \\
\hline $10 X-2,137-141$ & 133.49 & 15.45 & $\mathrm{BD}$ & $\mathrm{BD}$ & $\mathrm{N}$ & 3.703 & 2.2 \\
\hline $11 X-1,136.5-140.5$ & 141.57 & 16.01 & $\mathrm{BD}$ & $\mathrm{BD}$ & $\mathrm{N}$ & 6.208 & 1.3 \\
\hline
\end{tabular}

$\mathrm{BD}=$ below detection

Table T8. Concentrations of $\mathrm{H}_{2}$ and $\mathrm{CH}_{4}$ in science gas, Site $\mathrm{C} 0017$.

\begin{tabular}{|c|c|c|c|c|c|c|}
\hline $\begin{array}{l}\text { Hole, core, section, } \\
\text { interval }(\mathrm{cm})\end{array}$ & $\begin{array}{l}\text { Depth } \\
\text { (mbsf) }\end{array}$ & $\begin{array}{c}\mathrm{H}_{2} \text { in } \\
\text { headspace } \\
(\mathrm{ppm})\end{array}$ & $\begin{array}{c}\mathrm{CH}_{4} \text { in } \\
\text { headspace } \\
(\mathrm{ppm})\end{array}$ & $\begin{array}{c}\text { Sample } \\
\text { mass } \\
(\mathrm{g})\end{array}$ & $\begin{array}{l}\mathrm{H}_{2} \text { in } \\
\text { pore water } \\
(\mathrm{nM})\end{array}$ & $\begin{array}{l}\mathrm{CH}_{4} \text { in } \\
\text { pore water } \\
(\mu \mathrm{M})\end{array}$ \\
\hline \multicolumn{7}{|l|}{$331-$} \\
\hline C0017A-1H-1, 136-140 & 1.36 & $\mathrm{BD}$ & $\mathrm{BD}$ & 6.4 & $\mathrm{BD}$ & $\mathrm{BD}$ \\
\hline C0017A-1H-3, 137-141 & 4.18 & BD & $\mathrm{BD}$ & 5.3 & $\mathrm{BD}$ & $\mathrm{BD}$ \\
\hline C0017B-1H-1, 136.5-140.5 & 10.17 & $\mathrm{BD}$ & $\mathrm{BD}$ & 4.3 & $\mathrm{BD}$ & $\mathrm{BD}$ \\
\hline C0017B-1H-3, 137-141 & 13.00 & 1.7 & BD & 5.3 & 227.2 & BD \\
\hline C0017B-1H-5, 138-142 & 15.82 & $\mathrm{BD}$ & $\mathrm{BD}$ & 7.3 & $\mathrm{BD}$ & $\mathrm{BD}$ \\
\hline C0017C-1H-1, 137-141 & 19.67 & $\mathrm{BD}$ & $\mathrm{BD}$ & 3.2 & $\mathrm{BD}$ & $\mathrm{BD}$ \\
\hline C0017C-1H-4, 137-141 & 23.90 & 26.7 & $\mathrm{BD}$ & 6.3 & 4186.1 & $\mathrm{BD}$ \\
\hline C0017D-2H-1, 137-141 & 27.80 & $\mathrm{BD}$ & $\mathrm{BD}$ & 4.7 & BD & $\mathrm{BD}$ \\
\hline $\mathrm{C} 0017 \mathrm{C}-2 \mathrm{H}-4,136.5-140.5$ & 32.55 & $\mathrm{BD}$ & $\mathrm{BD}$ & 3.7 & $\mathrm{BD}$ & $\mathrm{BD}$ \\
\hline C0017D-1H-1, 137-141 & 61.34 & $\mathrm{BD}$ & 1.3 & 6.4 & $\mathrm{BD}$ & 0.2 \\
\hline C0017D-1H-3, 137-141 & 64.09 & $\mathrm{BD}$ & $\mathrm{BD}$ & 2.6 & $\mathrm{BD}$ & $\mathrm{BD}$ \\
\hline C0017D-1H-5, 137-141 & 66.84 & 2.9 & $\mathrm{BD}$ & 4.2 & 477.8 & $\mathrm{BD}$ \\
\hline C0017D-2H-1, 137-141 & 70.55 & $\mathrm{BD}$ & $\mathrm{BD}$ & 3.5 & $\mathrm{BD}$ & $\mathrm{BD}$ \\
\hline C0017D-2H-3, 137-141 & 73.34 & 2.4 & $\mathrm{BD}$ & 2.1 & 769.2 & $\mathrm{BD}$ \\
\hline C0017D-2H-4, 137-141 & 74.74 & $\mathrm{BD}$ & $\mathrm{BD}$ & 3.7 & $\mathrm{BD}$ & $\mathrm{BD}$ \\
\hline C0017D-6X-1, 124-128 & 95.44 & $\mathrm{BD}$ & $\mathrm{BD}$ & 6.1 & $\mathrm{BD}$ & $\mathrm{BD}$ \\
\hline C0017D-7H-2, 137-141 & 106.34 & $\mathrm{BD}$ & $\mathrm{BD}$ & 3.9 & $\mathrm{BD}$ & $\mathrm{BD}$ \\
\hline C0017D-7H-4, 137.5-141.5 & 109.01 & $\mathrm{BD}$ & $\mathrm{BD}$ & 6.5 & $\mathrm{BD}$ & $\mathrm{BD}$ \\
\hline C0017D-7H-5, 137.5-141.5 & 110.35 & $\mathrm{BD}$ & $\mathrm{BD}$ & 4.7 & $\mathrm{BD}$ & $\mathrm{BD}$ \\
\hline C0017D-8T-CC, 5-9 & 112.25 & $\mathrm{BD}$ & $\mathrm{BD}$ & 0.3 & $\mathrm{BD}$ & $\mathrm{BD}$ \\
\hline C0017D-9X-3, 0-4 & 122.99 & BD & $\mathrm{BD}$ & 3.9 & $\mathrm{BD}$ & $\mathrm{BD}$ \\
\hline C0017D-9X-4, 137-141 & 125.44 & $\mathrm{BD}$ & BD & 4.4 & $B D$ & $B D$ \\
\hline C0017D-9X-6, 137-141 & 127.98 & BD & $\mathrm{BD}$ & 4.0 & $\mathrm{BD}$ & $\mathrm{BD}$ \\
\hline C0017D-10X-2, 137-141 & 133.49 & 2.9 & 4.6 & 4.0 & 1184.7 & 1.9 \\
\hline C0017D-11X-1, 136.5-140.5 & 141.57 & $\mathrm{BD}$ & 7.6 & 6.2 & BD & 1.4 \\
\hline C0017D-11X-2, 136.5-140.5 & 142.97 & 1.3 & 4.7 & 5.3 & 328.7 & 1.2 \\
\hline
\end{tabular}

$\mathrm{BD}=$ below detection . 
Table T9. Carbon, nitrogen, and sulfur, Site C0017.

\begin{tabular}{|c|c|c|c|c|c|c|c|c|c|}
\hline $\begin{array}{l}\text { Core, section, } \\
\text { interval }(\mathrm{cm})\end{array}$ & $\begin{array}{l}\text { Depth } \\
\text { (mbsf) }\end{array}$ & $\begin{array}{c}\text { IC } \\
\text { (wt\%) }\end{array}$ & $\begin{array}{l}\mathrm{CaCO}_{3} \\
(\text { wt\%) }\end{array}$ & $\begin{array}{c}\mathrm{TN} \\
\text { (wt\%) }\end{array}$ & $\begin{array}{c}\text { TC } \\
\text { (wt\%) }\end{array}$ & $\begin{array}{c}\text { TS } \\
\text { (wt\%) }\end{array}$ & $\begin{array}{l}\text { TOC } \\
\text { (wt\%) }\end{array}$ & TOC/TN & $\mathrm{TOC} / \mathrm{TS}$ \\
\hline \multicolumn{10}{|l|}{ 331-C0017A- } \\
\hline $1 \mathrm{H}-1,35.5-37.5$ & 0.36 & 1.681 & 14.004 & 0.096 & 2.505 & 0.471 & 0.824 & 8.626 & 1.752 \\
\hline $1 \mathrm{H}-2,76.5-78.5$ & 2.17 & 2.240 & 18.662 & 0.083 & 2.957 & 0.252 & 0.718 & 8.630 & 2.853 \\
\hline $1 \mathrm{H}-3,54-56$ & 3.35 & 0.928 & 7.735 & 0.019 & 1.082 & 0.096 & 0.154 & 8.269 & 1.609 \\
\hline $1 \mathrm{H}-4,122-124$ & 5.44 & 5.372 & 44.766 & BD & 5.547 & 0.035 & 0.175 & NA & 4.987 \\
\hline $1 \mathrm{H}-5,115-117$ & 6.79 & 2.092 & 17.435 & 0.099 & 2.996 & 0.200 & 0.904 & 9.091 & 4.519 \\
\hline $1 \mathrm{H}-6,62-64$ & 7.66 & 1.860 & 15.501 & 0.105 & 2.817 & 0.257 & 0.957 & 9.070 & 3.717 \\
\hline \multicolumn{10}{|l|}{ 331-C0017B- } \\
\hline $1 \mathrm{H}-1,103-105$ & 9.83 & 2.380 & 19.828 & 0.076 & 3.012 & 0.099 & 0.632 & 8.326 & 109.642 \\
\hline $1 \mathrm{H}-3,80-82$ & 12.43 & 1.612 & 13.434 & 0.091 & 2.399 & 0.273 & 0.787 & 8.604 & 94.079 \\
\hline $1 \mathrm{H}-4,80-82$ & 13.84 & 1.777 & 14.808 & 0.097 & 2.662 & 0.148 & 0.885 & 9.100 & 93.524 \\
\hline $1 \mathrm{H}-5,80-82$ & 15.24 & 2.018 & 16.819 & 0.093 & 2.807 & 0.332 & 0.789 & 8.513 & 91.843 \\
\hline $1 \mathrm{H}-6,57-59$ & 16.43 & 1.114 & 9.280 & 0.020 & 1.279 & 0.244 & 0.165 & 8.128 & 399.191 \\
\hline $1 \mathrm{H}-7,80-82$ & 18.07 & 1.686 & 14.052 & 0.086 & 2.424 & 0.236 & 0.737 & 8.525 & 98.569 \\
\hline \multicolumn{10}{|l|}{ 331-C0017C- } \\
\hline $1 \mathrm{H}-1,114-116$ & 19.44 & 1.288 & 10.735 & 0.033 & 1.570 & 0.102 & 0.281 & 8.611 & 2.772 \\
\hline $1 \mathrm{H}-2,118-120$ & 20.89 & 3.082 & 25.682 & 0.067 & 3.634 & 0.071 & 0.552 & 8.272 & 7.729 \\
\hline $1 \mathrm{H}-3,70-72$ & 21.82 & 1.669 & 13.909 & 0.081 & 2.343 & 0.166 & 0.674 & 8.357 & 4.047 \\
\hline $1 \mathrm{H}-4,64-66$ & 23.17 & 0.706 & 5.883 & 0.016 & 0.840 & 0.126 & 0.134 & 8.162 & 1.061 \\
\hline $1 \mathrm{H}-5,60-62$ & 24.54 & 2.955 & 24.622 & 0.073 & 3.611 & 0.115 & 0.656 & 8.931 & 5.701 \\
\hline $1 \mathrm{H}-6,97-99$ & 26.32 & 3.846 & 32.052 & 0.034 & 3.972 & 0.032 & 0.125 & 3.720 & 3.948 \\
\hline $1 \mathrm{H}-7,73-75$ & 27.49 & 0.058 & 0.486 & 0.007 & 0.083 & 0.081 & 0.024 & 3.397 & 0.304 \\
\hline $2 \mathrm{H}-1,90-92$ & 28.70 & 0.031 & 0.255 & 0.006 & 0.054 & 0.098 & 0.024 & 3.954 & 0.244 \\
\hline $2 \mathrm{H}-2,97-99$ & 30.17 & 5.070 & 42.247 & 0.025 & 5.165 & 0.049 & 0.096 & 3.790 & 1.934 \\
\hline $2 \mathrm{H}-3,30-32$ & 30.58 & 0.049 & 0.410 & 0.007 & 0.076 & 0.119 & 0.027 & 4.015 & 0.224 \\
\hline $2 \mathrm{H}-4,84-86$ & 31.93 & 0.004 & 0.031 & BD & 0.011 & 0.060 & 0.007 & NA & 0.119 \\
\hline $2 \mathrm{H}-5,50-52$ & 32.99 & 0.002 & 0.013 & BD & 0.011 & 0.067 & 0.010 & NA & 0.143 \\
\hline $2 \mathrm{H}-6,60-62$ & 34.50 & 0.002 & 0.013 & $\mathrm{BD}$ & 0.008 & 0.089 & 0.007 & NA & 0.077 \\
\hline $2 \mathrm{H}-7,45-47$ & 35.76 & 0.004 & 0.030 & $\mathrm{BD}$ & 0.012 & 0.068 & 0.008 & NA & 0.118 \\
\hline \multicolumn{10}{|l|}{ 331-C0017D- } \\
\hline $1 \mathrm{H}-1,131-133$ & 61.31 & 0.021 & 0.175 & BD & 0.037 & 0.096 & 0.016 & NA & 0.162 \\
\hline 1H-2, 99-101 & 62.40 & 0.002 & 0.013 & 0.006 & 0.023 & 0.057 & 0.022 & 3.389 & 0.379 \\
\hline $1 \mathrm{H}-3,121-123$ & 64.03 & 0.001 & 0.012 & 0.010 & 0.033 & 0.038 & 0.031 & 3.113 & 0.834 \\
\hline $1 \mathrm{H}-4,29-31$ & 64.52 & 0.000 & 0.000 & 0.010 & 0.035 & 0.029 & 0.035 & 3.382 & 1.210 \\
\hline $1 \mathrm{H}-5,48-50$ & 66.12 & 0.000 & 0.000 & 0.011 & 0.035 & 0.044 & 0.035 & 3.168 & 0.802 \\
\hline $1 \mathrm{H}-6,26-28$ & 67.31 & 0.002 & 0.014 & 0.013 & 0.045 & 0.040 & 0.043 & 3.294 & 1.071 \\
\hline $1 \mathrm{H}-7,30-32$ & 68.76 & 0.007 & 0.058 & 0.006 & 0.037 & 0.029 & 0.030 & 4.779 & 1.051 \\
\hline $2 \mathrm{H}-1,120-122$ & 70.40 & 0.029 & 0.239 & BD & 0.049 & 0.084 & 0.020 & NA & 0.236 \\
\hline $2 \mathrm{H}-2,112-114$ & 71.73 & 0.001 & 0.008 & 0.041 & 0.101 & 0.049 & 0.100 & 2.459 & 2.046 \\
\hline $2 \mathrm{H}-3,52-54$ & 72.55 & 0.002 & 0.013 & 0.042 & 0.159 & 0.031 & 0.158 & 3.739 & 5.055 \\
\hline $2 \mathrm{H}-4,51.5-53.5$ & 73.95 & 0.000 & 0.003 & BD & 0.012 & 0.120 & 0.012 & NA & 0.099 \\
\hline $2 \mathrm{H}-5,65.5-67.5$ & 75.50 & 0.001 & 0.007 & $\mathrm{BD}$ & 0.016 & 0.053 & 0.015 & NA & 0.287 \\
\hline $2 \mathrm{H}-6,62-64$ & 76.87 & 0.024 & 0.199 & 0.087 & 0.770 & 0.136 & 0.746 & 8.613 & 5.479 \\
\hline $2 \mathrm{H}-7,81.5-83.5$ & 78.48 & 0.001 & 0.005 & $\mathrm{BD}$ & 0.024 & 0.073 & 0.023 & NA & 0.320 \\
\hline $6 X-1,63-65$ & 94.83 & 0.776 & 6.466 & 0.043 & 1.155 & 0.248 & 0.379 & 8.809 & 1.531 \\
\hline $6 X-2,16-18$ & 95.64 & 0.877 & 7.308 & 0.051 & 1.323 & 0.377 & 0.446 & 8.805 & 1.184 \\
\hline $7 \mathrm{H}-2,30-32$ & 105.41 & 0.814 & 6.781 & 0.061 & 1.355 & 0.182 & 0.541 & 8.879 & 2.978 \\
\hline $7 \mathrm{H}-3,134-136$ & 107.86 & 0.599 & 4.991 & 0.022 & 0.787 & 0.112 & 0.188 & 8.504 & 1.681 \\
\hline 7H-4, 110-112 & 109.02 & 0.553 & 4.606 & 0.061 & 1.075 & 0.468 & 0.522 & 8.608 & 1.116 \\
\hline 7H-5, 42-44 & 109.76 & 0.083 & 0.695 & 0.008 & 0.162 & 0.713 & 0.078 & 9.918 & 0.110 \\
\hline $7 \mathrm{H}-6,66-68$ & 111.41 & 0.706 & 5.881 & 0.018 & 0.728 & 0.430 & 0.023 & 1.256 & 0.053 \\
\hline $8 \mathrm{~T}-\mathrm{CC}, 0-2$ & 112.20 & 0.699 & 5.826 & 0.043 & 1.077 & 0.430 & 0.378 & 8.756 & 0.879 \\
\hline $7 \mathrm{H}-\mathrm{CC}, 22-24$ & 112.43 & 0.001 & 0.011 & $\mathrm{BD}$ & 0.019 & 0.014 & 0.017 & NA & 1.257 \\
\hline $9 X-2,110-112$ & 122.91 & 0.913 & 7.611 & 0.046 & 1.273 & 0.468 & 0.360 & 7.798 & 0.769 \\
\hline $9 X-4,100-102$ & 125.47 & 0.915 & 7.627 & 0.049 & 1.312 & 0.545 & 0.397 & 8.091 & 0.729 \\
\hline $9 X-6,100-102$ & 128.29 & 0.879 & 7.326 & 0.044 & 1.239 & 0.276 & 0.360 & 8.135 & 1.304 \\
\hline $9 X-8,70-72$ & 130.81 & 0.956 & 7.968 & 0.051 & 1.368 & 0.247 & 0.412 & 8.012 & 1.669 \\
\hline $10 X-2,60-62$ & 132.72 & 0.525 & 4.373 & 0.021 & 0.738 & 0.224 & 0.213 & 10.009 & 0.951 \\
\hline $10 X-4,32-34$ & 135.26 & 1.166 & 9.720 & 0.049 & 1.625 & 0.115 & 0.459 & 9.277 & 3.991 \\
\hline $10 X-C C, 40-42$ & 137.12 & 1.045 & 8.704 & 0.058 & 1.512 & 0.179 & 0.467 & 8.027 & 2.614 \\
\hline 11X-1, 70-72 & 140.90 & 1.219 & 10.159 & 0.019 & 1.474 & 0.035 & 0.255 & 13.603 & 7.271 \\
\hline $11 X-2,68-70$ & 142.29 & 0.482 & 4.017 & 0.047 & 0.895 & 0.106 & 0.413 & 8.702 & 3.893 \\
\hline $11 X-3,75-77$ & 143.76 & 0.002 & 0.014 & 0.046 & 0.302 & 0.048 & 0.300 & 6.488 & 6.239 \\
\hline $11 \mathrm{X}-\mathrm{CC}, 33-35$ & 144.67 & BD & $\mathrm{BD}$ & 0.007 & 0.038 & 0.078 & 0.038 & 5.139 & 0.490 \\
\hline
\end{tabular}

Notes: $\mathrm{IC}=$ inorganic carbon, $\mathrm{TN}=$ total nitrogen, $\mathrm{TC}=$ total carbon, $\mathrm{TS}=$ total sulfur, $\mathrm{TOC}=$ total organic carbon. $\mathrm{BD}=$ below detection. $\mathrm{NA}=$ not applicable. 
Table T10. Results of direct cell counting, Site C0017.

\begin{tabular}{ccc}
\hline Core, section & $\begin{array}{c}\text { Depth } \\
\text { (mbsf) }\end{array}$ & $\begin{array}{c}\text { Cells/mL } \\
\text { sediment }\end{array}$ \\
\hline $331-$ C0017A- & & \\
$1 \mathrm{H}-1$ & 0.65 & $2.35 \mathrm{E}+07$ \\
$1 \mathrm{H}-5$ & 6.37 & $3.22 \mathrm{E}+07$ \\
$331-\mathrm{C} 0017 \mathrm{~B}-$ & & \\
$1 \mathrm{H}-2$ & 10.811 & $2.39 \mathrm{E}+07$ \\
$1 \mathrm{H}-5$ & 14.802 & $9.51 \mathrm{E}+05$ \\
$331-\mathrm{C} 0017 \mathrm{C}-$ & & \\
$1 \mathrm{H}-2$ & 20.088 & $4.42 \mathrm{E}+06$ \\
$1 \mathrm{H}-5$ & 24.632 & $8.42 \mathrm{E}+06$ \\
$1 \mathrm{H}-7$ & 26.579 & $1.45 \mathrm{E}+06$ \\
$2 \mathrm{H}-1$ & 28.35 & $2.52 \mathrm{E}+06$ \\
$2 \mathrm{H}-2$ & 29.95 & $2.52 \mathrm{E}+06$ \\
$331-\mathrm{C} 0017 \mathrm{D}-$ & & \\
$1 \mathrm{H}-3$ & 63.633 & $7.51 \mathrm{E}+05$ \\
$1 \mathrm{H}-5$ & 66.382 & $5.81 \mathrm{E}+05$ \\
$1 \mathrm{H}-6$ & 68.052 & ND \\
$1 \mathrm{H}-6$ & 68.262 & ND \\
$6 \mathrm{X}-1$ & 94.96 & ND \\
$7 \mathrm{H}-4$ & 108.197 & ND \\
$9 \mathrm{X}-8$ & 130.1 & ND \\
$10 \mathrm{X}-4$ & 136.145 & ND \\
$11 \mathrm{X}-1$ & 141.1 & ND \\
\hline & \multicolumn{2}{c}{} \\
\hline & &
\end{tabular}

$\mathrm{ND}=$ not detected

Table T11. Results of contamination tests using fluorescent microspheres, Site C0017.

\begin{tabular}{|c|c|c|c|}
\hline \multirow[b]{2}{*}{ Core, section } & \multirow{2}{*}{$\begin{array}{l}\text { Depth } \\
\text { (mbsf) }\end{array}$} & \multicolumn{2}{|c|}{ Spheres $/ \mathrm{mL}$ sediment } \\
\hline & & Interior & Outer edge \\
\hline \multicolumn{4}{|l|}{ 331-C0017A- } \\
\hline $1 \mathrm{H}-1$ & 0.65 & ND & $1.28 \mathrm{E}+03$ \\
\hline $1 \mathrm{H}-5$ & 6.37 & ND & $2.91 \mathrm{E}+03$ \\
\hline \multicolumn{4}{|l|}{ 331-C0017B- } \\
\hline $1 \mathrm{H}-2$ & 10.811 & ND & $2.45 \mathrm{E}+04$ \\
\hline $1 \mathrm{H}-5$ & 14.802 & ND & $2.32 \mathrm{E}+02$ \\
\hline \multicolumn{4}{|l|}{ 331-C0017C- } \\
\hline $1 \mathrm{H}-2$ & 20.088 & ND & $6.99 \mathrm{E}+04$ \\
\hline $1 \mathrm{H}-5$ & 24.632 & ND & $3.05 \mathrm{E}+03$ \\
\hline $1 \mathrm{H}-7$ & 26.579 & ND & ND \\
\hline $2 \mathrm{H}-1$ & 28.35 & ND & $9.59 \mathrm{E}+03$ \\
\hline $2 \mathrm{H}-2$ & 29.95 & ND & $1.45 \mathrm{E}+02$ \\
\hline \multicolumn{4}{|l|}{ 331-C0017D- } \\
\hline $1 \mathrm{H}-3$ & 63.633 & ND & ND \\
\hline $1 \mathrm{H}-5$ & 66.382 & ND & ND \\
\hline $1 \mathrm{H}-6$ & 68.052 & ND & ND \\
\hline $2 \mathrm{H}-5$ & 74.873 & ND & $5.08 \mathrm{E}+03$ \\
\hline $7 \mathrm{H}-4$ & 108.197 & ND & $6.97 \mathrm{E}+03$ \\
\hline
\end{tabular}

$\mathrm{ND}=$ not detected 
Table T12. Results of contamination tests using fluorescent microspheres, Site C0017.

\begin{tabular}{|c|c|c|c|c|c|c|c|}
\hline \multirow[b]{2}{*}{ Core, section } & \multirow{2}{*}{$\begin{array}{l}\text { Depth } \\
\text { (mbsf) }\end{array}$} & \multicolumn{2}{|c|}{$\begin{array}{c}\text { PFT } \\
\text { in test vial gas phase } \\
(\mathrm{ppm})\end{array}$} & \multicolumn{2}{|c|}{$\begin{array}{l}\text { Sample weight } \\
\text { in test vial } \\
(\mathrm{g})\end{array}$} & \multicolumn{2}{|c|}{$\begin{array}{c}\text { PFT } \\
\text { per g sample } \\
(\mathrm{ppm})\end{array}$} \\
\hline & & Interior & Outer edge & Interior & Outer edge & Interior & Outer edge \\
\hline \multicolumn{8}{|l|}{ 331-C0017A- } \\
\hline $1 \mathrm{H}-1$ & 0.65 & ND & $5.16 \mathrm{E}-02$ & 1.17 & 3.38 & ND & $1.53 \mathrm{E}-02$ \\
\hline $1 \mathrm{H}-5$ & 6.37 & ND & $4.52 \mathrm{E}-02$ & 2.47 & 0.91 & ND & 4.97E-02 \\
\hline \multicolumn{8}{|l|}{ 331-C0017B- } \\
\hline $1 \mathrm{H}-2$ & 10.811 & ND & $1.61 \mathrm{E}-01$ & 2.17 & 1.95 & ND & $8.26 \mathrm{E}-02$ \\
\hline $1 \mathrm{H}-5$ & 14.802 & ND & $5.99 \mathrm{E}-02$ & 3.83 & 1.78 & ND & 3.37E-02 \\
\hline \multicolumn{8}{|l|}{ 331-C0017C- } \\
\hline $1 \mathrm{H}-2$ & 20.088 & ND & 4.93E-02 & 5.21 & 1.97 & ND & $2.50 \mathrm{E}-02$ \\
\hline $1 \mathrm{H}-7$ & 26.579 & ND & $1.71 \mathrm{E}-03$ & 0.78 & 1.43 & ND & $1.20 \mathrm{E}-03$ \\
\hline $2 \mathrm{H}-2$ & 29.95 & ND & $1.21 \mathrm{E}-02$ & 4.95 & 3.08 & ND & $3.93 \mathrm{E}-03$ \\
\hline \multicolumn{8}{|l|}{ 331-C0017D- } \\
\hline $1 \mathrm{H}-3$ & 63.633 & $2.30 \mathrm{E}-03$ & $2.03 \mathrm{E}-02$ & 1.17 & 2.73 & $1.97 \mathrm{E}-03$ & $7.44 \mathrm{E}-03$ \\
\hline $1 \mathrm{H}-5$ & 66.382 & $5.94 \mathrm{E}-03$ & $3.23 \mathrm{E}-03$ & 2.25 & 2.93 & $2.64 \mathrm{E}-03$ & $1.10 \mathrm{E}-03$ \\
\hline $1 \mathrm{H}-6$ & 68.052 & ND & $4.41 \mathrm{E}-03$ & 2.56 & 0.53 & ND & $8.32 \mathrm{E}-03$ \\
\hline $2 \mathrm{H}-5$ & 74.873 & ND & $8.23 \mathrm{E}-03$ & 2.81 & 3.89 & ND & $2.12 \mathrm{E}-03$ \\
\hline $6 \mathrm{X}-1$ & 94.96 & ND & $4.12 \mathrm{E}-03$ & 3.54 & 2.22 & ND & $1.86 \mathrm{E}-03$ \\
\hline $7 \mathrm{H}-4$ & 108.197 & $3.94 \mathrm{E}-03$ & $5.99 \mathrm{E}-03$ & 2.41 & 4.06 & $1.63 \mathrm{E}-03$ & $1.48 \mathrm{E}-03$ \\
\hline $9 X-8$ & 130.1 & $6.56 \mathrm{E}-03$ & 1.37E-02 & 3.29 & 4.60 & $1.99 \mathrm{E}-03$ & $2.98 \mathrm{E}-03$ \\
\hline $10 X-4$ & 136.1 & $3.36 \mathrm{E}-03$ & NT & 3.77 & NT & $8.91 \mathrm{E}-04$ & NT \\
\hline $11 X-1$ & 141.1 & $2.19 \mathrm{E}-02$ & $4.93 \mathrm{E}-02$ & 4.66 & 2.92 & $4.70 \mathrm{E}-03$ & $1.69 \mathrm{E}-02$ \\
\hline
\end{tabular}

PFT = perfluorocarbon tracer. ND = not detected, $\mathrm{NT}=$ not tested.

Table T13. Cultivation experiment results for putative iron oxidizers, Site C0017.

\begin{tabular}{|c|c|c|c|c|}
\hline \multicolumn{2}{|c|}{ Depth (mbsf) } & \multirow{2}{*}{$\begin{array}{l}\text { Hole, core, section, } \\
\text { interval }(\mathrm{cm})\end{array}$} & \multicolumn{2}{|c|}{ Growth media } \\
\hline Top & Bottom & & ASW A & ASW B \\
\hline \multicolumn{5}{|c|}{$331-$} \\
\hline 0.65 & 0.80 & C0017A-1H-1, 65-80 & - & ND \\
\hline 20.09 & 20.23 & $\mathrm{C} 0017 \mathrm{C}-1 \mathrm{H}-2,45-60$ & + & + \\
\hline 24.63 & 24.82 & C0017C-1H-5, 95-115 & - & ND \\
\hline 26.26 & 26.28 & C0017C-1H-6, 119-121 & +++ & - \\
\hline 26.57 & 26.76 & C0017C-1H-7, 15-35 & ++ & - \\
\hline 26.57 & 26.76 & C0017C-1H-7, 15-35 & +++ & - \\
\hline 28.35 & 28.45 & C0017C-2H-1, 55-65 & +++ & ++ \\
\hline 29.95 & 30.15 & C0017C-2H-2, 75-95 & - & - \\
\hline
\end{tabular}

$+++=$ good growth (lots of cells) $++=$ medium growth,$+=$ little growth (a few cells),$-=$ no growth. ND = no data.

Table T14. Average porosity, bulk density, grain density, thermal conductivity, and formation factor, Site C0017.

\begin{tabular}{lccccc}
\hline Hole & $\begin{array}{c}\text { Porosity } \\
(\%)\end{array}$ & $\begin{array}{c}\text { Bulk density } \\
\left(\mathrm{g} / \mathrm{cm}^{3}\right)\end{array}$ & $\begin{array}{c}\text { Grain density } \\
\left(\mathrm{g} / \mathrm{cm}^{3}\right)\end{array}$ & $\begin{array}{c}\text { Thermal } \\
\text { conductivity } \\
(\mathrm{W} /[\mathrm{m} \cdot \mathrm{K}])\end{array}$ & $\begin{array}{c}\text { Formation } \\
\text { factor }\end{array}$ \\
\hline 331- & & & & & \\
C0017A & $0.65 \pm 0.07$ & $1.57 \pm 0.09$ & $2.60 \pm 0.06$ & $0.94 \pm 0.09$ & $3.94 \pm 1.22$ \\
C0017B & $0.63 \pm 0.05$ & $1.60 \pm 0.04$ & $2.61 \pm 0.15$ & $1.07 \pm 0.06$ & $3.77 \pm 0.40$ \\
C0017C & $0.65 \pm 0.14$ & $1.56 \pm 0.23$ & $2.54 \pm 0.25$ & $0.83 \pm 0.27$ & $4.57 \pm 2.11$ \\
C0017D & $0.52 \pm 0.13$ & $1.81 \pm 0.25$ & $2.62 \pm 0.21$ & $1.23 \pm 0.32$ & $6.52 \pm 1.68$ \\
Average: & $0.57 \pm 0.13$ & $1.71 \pm 0.25$ & $2.60 \pm 0.20$ & $1.09 \pm 0.30$ & $5.41 \pm 1.98$ \\
\hline
\end{tabular}

Error is the standard deviation of the average. 
Table T15. APCT3 temperature measurements, Site C0017.

\begin{tabular}{lcccc}
\hline Hole, core & Unit & $\begin{array}{c}\text { Depth } \\
\mathrm{CSF}(\mathrm{m})\end{array}$ & $\begin{array}{c}\text { Equilibrium } \\
\text { temperature } \\
\left({ }^{\circ} \mathrm{C}\right)\end{array}$ & $\begin{array}{c}\text { Bottom water } \\
\text { temperature } \\
\left({ }^{\circ} \mathrm{C}\right)\end{array}$ \\
\hline 331- & & & & \\
C0017B-1H & I & 18.3 & 5.24 & 4.89 \\
C0017C-2H & & 37.3 & 5.97 & 5.23 \\
C0017D-1H & II & 69.2 & 25.08 & 4.38 \\
C0017D-2H & & 78.7 & 35.18 & 4.48 \\
C0017D-3H & & 84.7 & 39.4 & 4.57 \\
C0017D-4H & & 84.7 & - & 5.40 \\
C0017D-7H & III & 112.2 & 44.12 & 5.75 \\
C0017D-12H & & 150.7 & 90 & 4.24 \\
\hline
\end{tabular}

$-=$ no temperature calculated. ${ }^{*}=$ temperature from thermoseal strips.

Table T16. Measured values for the thermal gradient, thermal conductivity, and estimated heat flow, Site C0017.

\begin{tabular}{lccc}
\hline Unit & $\begin{array}{c}\text { Thermal } \\
\text { gradient } \\
(\mathrm{K} / \mathrm{m})\end{array}$ & $\begin{array}{c}\text { Thermal } \\
\text { conductivity } \\
(\mathrm{W} /[\mathrm{m} \cdot \mathrm{K}])\end{array}$ & Heat flow \\
\hline I & 0.03 & 0.95 & 0.0285 \\
II & 0.43 & 0.82 & 0.3526 \\
III & 0.89 & 1.37 & 1.2193 \\
\hline
\end{tabular}

